\title{
COMPORTAMENTO AGROINDUSTRIAL DE SEIS VARIEDADES DE CANA-DE-AÇÚCAR (Saccharum spp) COM E SEM FERTIRRIGAÇÃO
}

\author{
ANTONIO CARLOS FERNANDES \\ Engenheiro Agrônomo
}

Orientador : JOSÉ PAULO STUPIELLO

\begin{abstract}
Dissertação apresentada à Escola Superior de Agricultura "Luiz de Queiroz", da Universidade de São Paulo, para obtenção do título de Mestre em Agronomia. Área de Concentração de Solos e Nutri. ção de Plantas.
\end{abstract}

P I R A C I C A B A

Estado de São Paulo - Brasil

Novembro - 1982

Def. 1983 
DEDICAÇÃO

Sr. Octāvio Fernandes

Meu querido pai, que lutou pela mi nha formação pessoal e profissional, 


\section{AGRADECIMENTOS}

A realização deste trabalho foi possivel devido a colabora ção, apoio e sugestões de:

- Prof. Dr. José Paulo Stupiello, que tem sido o incentivador de minha formação profissional, pela orientação desta dis sertação;

- Centro de Tecnologia Copersucar (Cooperativa Central dos Produtores de Açúcar e Álcool do Estado de São Paulo) que me possibilitou a realização do Curso de Pós-Graduação;

- Usina São João, Araras - SP, na pessoa de seus técnicos: Engo. Agrônomo Adilson José Rossetto, Engo. Agrônomo Anto nio Mario Leitão Medeiros, Engং. Agrônomo Iuiz Carı́us Miller, Sr. Santo Bussioli Filho e Sr. Antonio, pela inesti mável colaboração na condução dos trabalhos de campo, apoio material e valiosas sugestões;

- Engo. Agrônomo Bernardo Yasuhiro Ide e Técnico Agrỉcola Ade mar Vilhalva Ferreira, sem o.s quais, a realização desta dis sertação tornar-se-ia impraticável;

- Técnico Químico Abel Pereira da Silva e Sr. Hércio Apareci do Longatto, responsáveis pela condução das análises tecno lógicas com zelo profissional;

- Prof. Dr. Roberto Simionatto de Moraes, pelas sugestões da análise estatística e computação eletrônica dos dados;

- Srtas. Rosangela Lopes de Araujo Cintra e Eusa Maria Rodri gues de Souza pelos trabalhos de datilografia. 
INDICE

Păgina

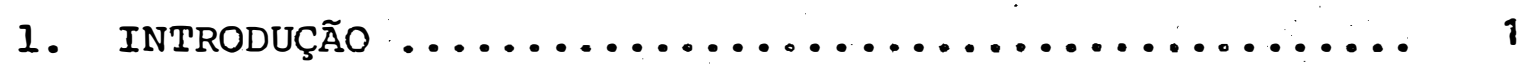

2. REVISÃO BIBLIOGRAFICA $\ldots \ldots \ldots \ldots \ldots \ldots \ldots \ldots \ldots \ldots$

2.1 Variedades de cana-de-açūcar ............ 3

2.2 Fertirrigação da cana-de-açūcar .......... 8

2.3 Vinhaça aplicada com caminhão-tanque ....... 13

3. Materiais e MEtodos...................... 17

3.1 Delineamento experimental ............. 17

3.2 Instalação e épocas ................. 17

3.3 Variedades ......................... 19

3.4 Fertirrigação e adubações .............. 21

3.5 Amostragens e avaliações .............. 23

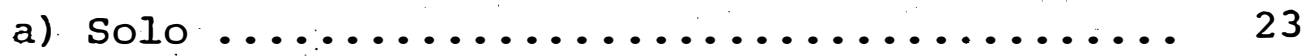

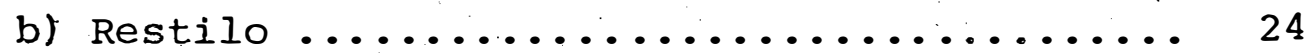

C) Cana-de-açúcar $\ldots \ldots \ldots \ldots \ldots \ldots \ldots \ldots . \ldots \ldots$

3.6 Colheita do experimento $\ldots \ldots \ldots \ldots \ldots \ldots \ldots .26$

4. RESUltados e discussões $\ldots \ldots \ldots \ldots \ldots \ldots \ldots \ldots \ldots . \ldots \ldots$

4.1. Curvas de maturação ................. 27

a) Area fertirrigada .................. 29

b) Ārea sem ferțirrigação ............. 34

4.2 Qualidade tecnológica da matérià-prima ...... 37

a) Fibra, umidade e caldo extraído : cana .... 38

b) Açúcares redutores, cinzas condutimetricas e fósforo inorgânico no caldo extraído .... 41

c) Brix, pol e pureza da cana-de-açücar ...... 47 
d) Açúcares totais por cento de cana ........ 47

4.3 Produtividade nas colheitas ............ 52

a) Rendimentos teóricos de açúcar e álcool ... 52

b) Produtividade de colmos ............. 57

c) Rendimentos teóricos por hectare ........ 59

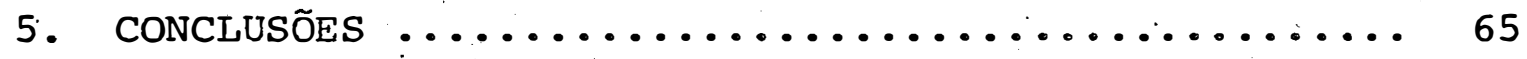

6. BIBLIOGRAFIA .........................67

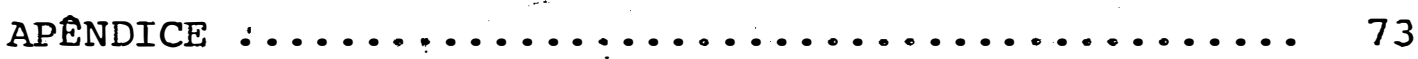


IISTA DE TABELAS

Tabela

Pāgina

1. Area total de parcelas $\left(\mathrm{m}^{2}\right) \ldots . . \ldots \ldots . . . .$.

2. Períodos de aplicação e dosagem do restilo nos três cortes do ensaio fertirrigado......

3. Resultados da análise química do solo coleta do de 0 a $30 \mathrm{~cm}$ de profundidade, antes do plantio da cana-de-açúcar...............

4. Composição média da mistura de vinhaça com ăguas residuais e dosagem de nutrientes apli cados nos tratamentos fertirrigados........

5. Coeficientes de correlação $(r)$ das equações quiuaráticas representativas do comportamento da maturação, expressas em açūcar teórico re cuperável (ATR) e nível de significāncia da

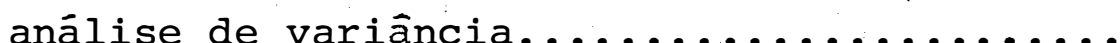

6. Dados meteorológicos observados na Estação Experimental de Araras - SP (IAA-PLANALSUCAR)

7. Resultados médios de fibra : cana (F) e dife rença minima significativa (dms) pelo teste de Tukey ao nível de 5\% de probabilidade....

8. Resultados médios de caldo extriaido : cana e diferença minima significativa (dms) pelo teste de Tukey ao nivel de 5\% de probabilida-

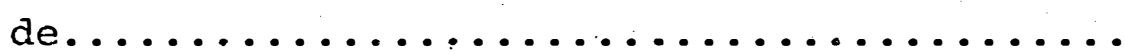

9. Resultados médios de umidade : cana e dife rença mínima significativa (dms) pelo teste de Tukey ao nível de 5\% de probabilidade....

10. Resultados médios de açúcares redutores \% caldo e diferença mínima significativa 
(dms) pelo teste de Tukey ao nível de 5\% de

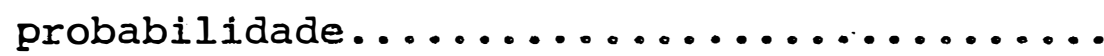

11. Resultados médios de cinzas condutimétricas \& caldo e diferença mínima significativa (dms) pelo teste de Tukey ao nível de 5\% de

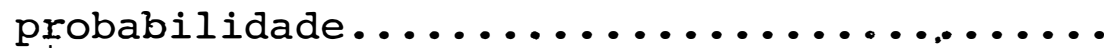

12. Resultados médios de fósforo inorgânico do caldo $\left(\mathrm{P}_{2} \mathrm{O}_{5}\right)$ em mg/litro e diferença mínima significativa (dms) pelo teste de Tukey ao nível de 5\% de probabilidade..............

13. Resuitados médios de Brix \% cana e diferen ça 'minima significativa (dms) pelo teste de Tukey ao nível de 5\% de probabilidade......

14. Resultados médios de pol : cana e diferença mínima significativa (dms) pelo teste de uㅜ key ao nível de 5\% de probabilidade........

15. Resultados médios de pureza da cana e dife rença mínima significativa (dms) pelo teste de Tukey ao nível de 5\% de probabilidade... Résultados médios de açúcares totais : cana e diferença mínima significativa (dms) pelo teste de Tukey ao nível de 5\% de probabili

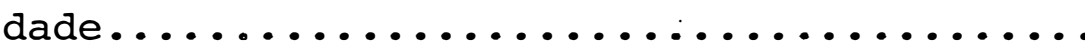

17. Resultados médios de açúcar recuperável (ATR) em $\mathrm{Kg} / \mathrm{t}$ de cana e diferença mínima significativa (dms) pelo teste de Tukey ao nível de 5\% de probabilidade.............

18. Resultados médios de álcool provável direto (EPD) em litros de álcool/t de cana e dife rença mínima significativa (dms) pelo teste de Tukey ao nível de 5\% de probabilidade...

19. Resultados médios de produtividade de col mos ( $t / h a)$ e diferènça mínima significativa 
Tabela

Pāgina

(dms) pelo teste de Tukey ao nível de 5\% de

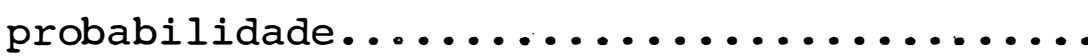

20. Resultados médios de produtividade de açu彑 car (t/ha) e diferença mínima significativa (dms) pelo teste de Tukey ao nível de 5\% de

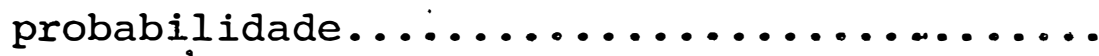

21. Resultados médios de produtividade de ál cool ( $\left.\mathrm{m}^{3} / \mathrm{ha}\right)$ e diferença mínima significati va (dms) pelo teste de Tukey ao nível de 5\% de probabilidade....................

22. Resultados médios mensais de fibra \% cana..

23. Resultados médios mensais de açúcares reduu

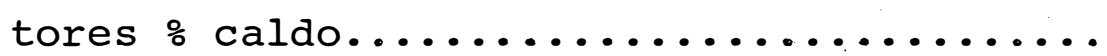

24. Tiesultados médios mensais de cinzas conduti métricas \% caldo....................

25. Resultados médios mensais de fósforo inorgâa nico $\left(\mathrm{P}_{2} \mathrm{O}_{5}\right)$ no caldo, em mg/litro......... 77

26. Resultados médios mensais de Brix \% cana... 78

27. Resultados médios mensais de pol \% cana.... 79

28. Resultados médios mensais de pureza \% cana. 80

29. Resultados médios mensais de açūçares to

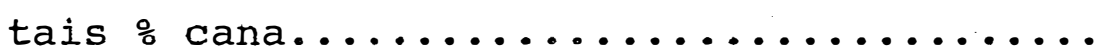

30. Resultados médios mensais de açúcar teórico recuperável (ATR), em $\mathrm{kg}$ açúcar/t de cana.. 


\section{LISTA DE FIGURAS}

Figura

Curvas de maturação em função do açūcar teó rico recuperável (ATR) em kg/t cana, na área fertirrigada e sem fertirrigação, du rante o 19 corte em 1979 ...............

2. Curvas de maturação em função do açúcar teó rico recuperável (ATR) em kg/t cana, na área fertirrigada e sem fertirrigação, du

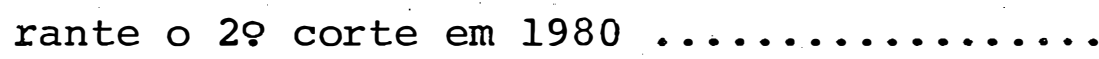

3. Curvas de maturação em função do açúcar teó rico recuperável (ATR) em $\mathrm{kg} / \mathrm{t}$ cana, na área fertirrigada e sem fèrtirrgação, du

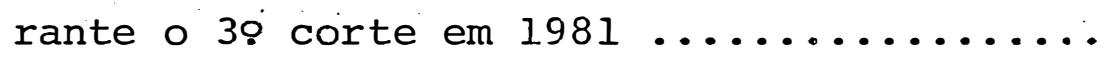

4. Curvas de maturação em função do açūcar teó rico recuperável (ATR) em kg/t cana, na ārea fertirrigada e sem fertirrigação, valo res médios para os très primeiros cortes .. 


\section{COMPORTAMENTO AGROINDUSTRIAL DE SEIS VARIEDADES DE CANA- -DE-ACUCAR (Saccharum spp) COM E SEM FERTIRRIGACÃO}

Orientador: Prof. Dr. José Paulo Stupiello

Candidato : Engo. Agro. Antonio Carlos Fernandes

RESUMO

O processamento industrial da cana-de-açúcar no Estado de São Paulo inclui normalmente a lavagem da matéria-prima, de modo a eliminar principalmente a terra incluicia na carga durante o carregamento mecânico. A água utilizada na la vagem recebe diversas destinações, sendo em algumas indūs trias misturada parcialmente com a vinhaça produzida na des tilaria e enviada $\therefore$ para. a. lavoura, e aplicada em al tas dosagens por sulcos de infiltração, recebendo a denomina çao de fertirrigação.

Esta técnica conduz, relativamente, a um maior desenvolvimento vegetativo da cana-de-açúcar, devido aos nu trientes, principalmente potássio e nitrogênio, e matéria-orgânica aplicados. Por outro lado, a maior produtividade conduz a uma matéria-prima de menor qualidade para a produção de açúcar ou de álcool.

o principal objetivo deste trabalho foi o de se avaliar a técnica da fertirrigação, utilizada normalmente pela Usina são João em Araras - SP, e seus efeitos sobre a ma turação, qualidade tecnológica e produtividades de seis varie dades de cana-de-açúcar, procurando o manejo adequado para as mesmas em condições fertirrigadas e sem fertirrigação. 
Para aplicação nesta dissertação, definiu-se a mistura de água da lavagem de cana com vinhaça, na propor çao aproximada de 10 para 1 , respectivamente, de restilo.

Os resultados obtidos com as variedades CB40-13, CB41-76, CB47-355, IAC48/65, IAC52/150 e NA56-79, mostraram que existe acentuado efeito varietal na resposta à fertirrigação.

Devido à redução na qualidade da matéria-prima, e pelo fato de as variedades fertirrigadas serem colhidas em maio e junho, para liberação dás áreas para aplicação dos efluentes que estão sendo produzidos, as vâ riedades com alto teor de sacarose apresentaram melhores resultados sob o aspecto agroindustrial. Assim, a NA56-79, CB40-13 e IAC52/150 mostraram-se as mais adequadas para cultivo em área fertirrigada, desde que sejam aprovadas pe. lo estado fitossanitário.

$A$ variedade $C B 47-355$ foi a que apresentou me nores variações do teor de sacarose, mas pode ser colhida somente após setembro. As maiores alterações foram obtidas com a CB41-76, que não pode ser recomendada para área com fertirrigação, devido ao relativo baixo rendimento de açū car e álcool por tonelada de cana, e com a NA56-79. Entre tanto, por ser esta uma variedade com altos teores de saca rose durante toda a safra, a redução de qualidade provocada pela fertirrigação não é suficiente para colocā-la em sí tuação inferior às demais.

A matéria-prima produzida em área fertirriga da mostrou-se mais adequada para produção de álcool direto, devido ao alto teor de cinzas do caldo e rendimento teóri co de álcool por hectare relativamente satisffatório.

De um modo geral, observou-se entre os dois experimentos que a aplicação de altos volumes de restilo resultou em elevação da produtividade de colmos em . 30\%, redução do rendimento de açù̀car teórico recuperável em 17\% 
e do álcool provável direto em 13\%, o que conduziu a um ren dimento de açúcar por hectare em média $6 \%$ maior, e de álcool por hectare em mais de $12 \%$.

A adoção da fertirrigação exige ainda estudos econômicos para se determinar se o acréscimo de açúcar ou álcool por hectare, produz receita maior do que a diferença entre os custos de adubação mineral e da fertïrrigação soma dos aos custos de corte, carregamento, transporte e processa mento de uma maior quantidade de cana-đe-açúcar.

Deve-se acrescentar, também, os custos de outro processo alternativo para o caso da não adoção da fertirrigação.

Sob condições não fertirrigadas, a NA56-79 mostrou-se significativamente superior as demais na média de três cortes para produtividade de açúcar ou de álcool. A va riedade CB40-13, devido à sua riqueza em sacarose e por ser - solo da área experimental de alta fertilidade natural, co locou-se em segundo Iugar em termos de produtividade de açū car ou álcool por hectare, na média dos três cortes, - embora sem diferir significativamente das demais. 
$x i i$

AGROINDUSTRIAL BEHAVIOR OF SIX SUGARCANE ISaccharum

spp) VARIETIES WITH AND WITHOUT FERTIRRIGATION

Adviser : Prof. Dr. José Paulo Stupiello

Candidate: Engo. Agro. Antonio Carlos Fernandes

SUMMARY

The Brazil National Alcohol Program (

PROÁL COOL), started during the 1975/76 crop, became one of . the most discussed projects in the sugar industry because of its magnitude (10.7 billion liters of alcohol in 1985), its socio-economic implications, and its waste disposal problems. The use of vinasse, the liquid organic residue of alcohol dis tillation, as fertilizer has been a pragmatic method of avoiding environmental pollution. Another pollutant, the water used to wash the cane, is applied by some sugar mills with vinasse at high rates to sugarcane fields in the system known as fertirrigation.

The mixture of vinasse (about 10\%) and cane wash water was applied to the furrows 6 months after planting the cane and soon after harvest of the first and second ratoons of six varieties (CB40-13, CB41-76, CB47-355, IAC48/65 IAC52/150 and NA56-79), and this treatment was compared with mineral fertilization in a randomized block trial.

The results of the 3 year experiment showed an average increase in cane productivity of 29 ton/ha $(+30 \%)$ due to better growth with the mixture. This higher yield affected sucrose content, resulting in a decrease of $20.0 \mathrm{~kg}$ 
$(-17 \%)$ of recoverable sugar per ton of cane, or 10,6 liters $(-13 \%)$ of probable alcohol per ton of cane. The yield. of sugar per hectare was enhanced by $710 \mathrm{~kg}(+6,3 \%)$ and direct alcohol by 980 liters $(+12,1 \%)$.

The varietal response showed that the varieties NA56-79, CB40-13 and IAC52/150 behaved better with fertirri gation due to their higher inherent levels of sucrose, since the higher nutrient dosage, mainly potassium and nitrogen, generally reduced the recoverable sugar or alcohol at the beginning of the crop.

The greater increase in estimated alcohol yield and the higher juice ash content may indicate that the fertir rigated varieties are more suitable for direct fermentation than for sigar production.

An economical study for an evaluation of the fertirrigation technique is necessary. The study should inclu de the differences in costs between this system an -mineral fertilization, the increase in harvest and milling costs due to more cane being produced, and lower replanting coast since fertirrigation can improve the life of stubble crops. 


\section{INTRODUÇÃO}

A cana-de-açúcar é extensivamente cultivada em muitos países para produção de açúcar, sendo poucos os que a utilizall para a obtenção de álcool diretamente por via fermen tativa, e apenas o Brasil mantém uma produção de álcool para combustível carburante em larga escala. Esta intensa ativida de da agroindústria do açúcar e do álcool tem gerado-necessí dade premente de novas pesquisas e desenvolvimento, de modo a solucionar os problemas do setor.

Após a criação do Programa Nacional do ß̉lcool (PROÁLCOOL), em 1975, com a meta de produzir mais de 10 bi lhões de litros de álcool por ano, em. prazo relativamente curto, o setor açucareiro e alcooleiro recebeu grande im pulso técnico e econômico. Para atingir a meta prevista há ne cessidade de aumentar a produtividade dos setores agricola e industrial, e conseguir a perfeita integração entre uma agricultura desenvolvida e uma conversão eficiente, assim co mo encontrar a melhor solução para o destino de residuos co mo: a vinhaça e as águas residuais.

o aumento da produtividade agrícola pode ser obtido por diversos meios, mas o manejo adequado das varieda des disponíveis e introdução de novas variedades representa a 
maneira mais eficiente e econômica. Para a vinhaça a solução mais adequada até o momento, foi apresentada há mais de três décadas por ALMEIDA et alii (1950) e ALMEIDA (1952), para a sua utilização na lavoura como fertilizante. Quanto as águas residuais, principalmente a água de lavagem da cana-de-ạ̧ú car, o mais viāvel parece ser o emprego de circuitos fecha dos, devido ao seu alto volume e menor potencial poluidor em relação a vinhaça.

O sistema de aplicação da vinhaça na lavaura e atualmente um dos aspectos a serem pesquisados para defini ção de sua exequibilidade como fertilizante. A aplicação do residuo in natura por meio de caminhões-tanque sobre a so queira da cána-de-açūcar representa uma das tecnologias com melhores possibilidades de sucesso. Outro sistema de aplica ção da vinhaça consiste na irrigação por sulcos de infiltia ção, dỉluída ou não com águas residuais da indústria, constî tuindo a fertirrigação, ou seja, irrigação fertilizante. A mistura de água da lavagem de cana com vinhaça foi definida nesta dissertação como restilo, embora este termo seja. algu mas vezes empregado como sinônimo para vinhaça, a qual rece be ainda denominações como vinhoto, garapão, etc.

o principal objetivo deste trabalho foi ava liar o comportamento agroindustrial de seis variedades de cana-de-açúcar, quanto aos efeitos da fertirrigação sobre a maturação, qualidade tecnológica e produtividade, a fim de definir o manejo adequado para as mesmas. 


\section{REVISÃO BIBLIOGRĀFICA}

2.1 Variedades de cana-de-açúcar

Dentre os fatores ãe produção da cana-de-açũcar controláveis pelo homem, a variedade destaca-se como aquele que pode oferecer as respostas mais eficientes, desde que se ja corretamente manejado.

O efeito da utilização de variedades melhoradas pode ser avaliado pela própria história da cultura no Brasil. Segundo JUNQUEIRA e DANTAS (1964), por mais de.três séculos foi cultivada uma única variedade, conhecida por "Crïoula" , substituída depois pela "Caiana" no inīcio do século XIX. So mente na década de 20 deste século o país passou a cultivar híbridos, que foram importados de Java (POJ) e da India (Co). Estas variedades POJ, segundo aqueles autores, introduziram no Brasil a "doença do mosaico", que dizimou os canaviais de variedades nobres.

O cultivo de híbridos obtidos nos programas bra sileiros de melhoramento deu-se por volta de 1950, com a in trodução das variedades de sigla CB e IAC, principalmente. Os resultados obtidos pelo IAA-PLANALSUCAR (1979, 1980 e 1981) sobre os levantamentos da área cultivada 
com cana-de-açúcar no Estado de São Paulo, mostraram que as 10 variedades mais cultivadas em 1978, 1979 e 1980 foram: NA56-79, CB41-76, IAC52/150, IAC48/65, CB47-355, IAC51/205, CB49-260, CB45-155, СB53-98 e CB46-47.

Os dados dos levantamentos mostraram que em 1980 cerca de 65\% da lavoura paulista era ocupada somente por três variedades de cana-de-açúcar: NA56-79, CB41-76 e IAC52/150. Verificou-se que as áreas cultivadas com algumas variedades encontravam-se em declíneo, como а CB4i-76 e CB46-47, ou mesmo deixaram de figurar entre as 10 principais, como a $\mathrm{CB} 40-13$, e outras mostrando acentuado crescimento, des tacando-se a NA56-79 e IAC52/150. A variedade NA56-79 surgiu no Estado de São Paulo há poucos anos, passando de 10\% da área cultivada em 1975 para quase 50\% em 1981, de acordo com COPERSUCAR (1982b).

Os resultados obtidos por

IAA-PLANALSUCAR (1979, 1980, e 1981), destacaram ainda que de 15 a 20\% da área cultivada com cana-de-açúcar era representada por varie dades catalogadas como outras diversas, o que demonstra a preocupação dos produtores quanto à substituição de varieda des através de experimentação própria, o que já havia sido constatado por BRIEGER (1978).

Utilizando os dados de produtividade de col mos ( $t / h a)$ obtidos em condições normais de trabalho na lavou ra própria de 11 usinas de açúcar na safra 80/81, a COPERSU CAR (1982c) observou que uma mesma variedade apresentou valo res diversos entre as unidades de produção; mesmo entre aque las localizadas na mesma região. O fator preponderante deste fato é a tecnologia de produção adotada pelos produtores, on de o manejo de variedades, contribui decisivamente para os re sultados. Em uma área de 26.700 ha, a NA56-79 apresentou uma produtividade média de $80 \mathrm{t} / \mathrm{h}$, a CB41-76 em 16.268 ha produ ziu 70 t/ha, a IAC52/150 em 6.365 ha resultou em 81 t/ha, a 
IAC48/65 em 3.243 ha. produziu 72 t/ha, a CB47-355 em 1.660 ha apresentou produtividade média de 70 t/ha e a CB40-13 em 1.648 ha mostrou 72 t/ha de produtividade de colmos. Con siderando-se a área total das 11 usinas estudadas de 82.646 ha a produtividade final foi de $72 \mathrm{t} / \mathrm{ha}$, o que faz com que das seis variedades citadas, somente a.CB41-76 e CB47-355 es tavam abaixo da média.

Naturalmente, estes dados referem-se a produti vidade de colmos, e não tratam do teor de sacarose ou rendi mento de açúcar e/ou álcool destas variedades.

A concentração de açúcar de uma variedade é um valor dependeñte do seu estágio de maturação e condições edafoclimáticas. Isto tem sido avaliado pelo programa de me lhoramento da cana-de-açúcar da COPERSUCAR (1982a), que de monstra a variabilidade em rendimento de açúcar que ocorre entre as variedades ou clones da sigla SP.

A avaliação de variedades de canà-de-açúcar sob o ponto de vista agroindustrial leva em consideração ba sicamente dois parâmetros: a riqueza em açúcar e a produtivi dade de colmos. Enquanto o primeiro valor é incontestavelmen te variável ao longo da safra, o rendimento agrícola ainda apresenta controvérsias quanto ao ganho de peso dos colmos no periodo da safra.

LINGERFELT et alii (1965) testaram quatro sis temas de manejo de variedades na República Dominicana, procu rando obter um maior rendimento de açúcar por tonelada de ca na através da progromação de colheita das sete principais va riedades cultivadas na região. Os autores não consideraram qualquer variação na produtividade de colmos no período de safra.

Na Âfrica do Sul, que apresenta um período de safra coincidente com o Estado de são Paulo, tem sido desenvolvidos numerosos trabalhos referentes às variedades. ROSSLER A MOBERLY (1972) trabalharam com cinco variedades e 
quatro épocas de colheita, tendo o plantio sido realizado em setembro de 1965, e as colheitas efetuadas em diferentes sa fras, entre 1966 e 1970. Os resultados mostraram para ROSSLER e MOBERLY (1972) que a cana planta deve ser colhida com 24 meses de idade, o segundo corte com 12 meses e o ter ceiro corte com 20 meses. Para obter-se estas conclusões os autores basearam-se somente nos maiores valores de $t$ pol/ha. As diferenças no teor de sacarose entre varie dade são pequenas no final da safra (novembro e dezembro) , mas no pico de maturação (setembro) ocorrem grandes variações, afirmam GOSNELL e KOENIG (1972). Os dados obtidos na Rodésia mostraram que enquanto a curva de maturação das três varieda des possui um comportamento normal, isto é, aumentando o teor de sacarose até setembro para depois decrescer, a produtivida de de colmcs nem sempre apresenta um comportamento regular. os autores, aliás, nem discutem os mesmos, atendo-se somente à produtividade de açǘcar.

Estudando os efeitos da idade e época de co lheita sobre a produtividade da cana-de-açücar irrigada, na África do Sul, ROSTRON (1972) observou que com a colheita da primeira soca entre 32 e 72 semanas após o primeiro corte, ocorreu uma redução no crescimento das soqueiras após 40 se manas de idade. O declíneo avaliado pelo autor dependeu da época do ano em que a cultura inicou o ćrescimento.

Um experimento envol.vendo duas variedades (NCo310 e NCo376), colheita em quatro épocas de safra (maio, julho, setembro e novembro) e diferentes idades $(10,12,14$, 16 e 18 meses) foi conduzido na Rodésia por LONSDALE e GOSNELL (1975). Os resultados mostraram que a época de co lheita tem considerável influência na produtividade e qualí dade da cana-de-açúcar, sendo os melhores resultados obtidos em julho e setembro uma vez que em maio a produtividade é pe quena devido à baixa qualidade das variedades estudadas, en quanto que em novembro há baixa produtividade de colmos. 
As variações na produtividade de colmos, ante riormente observadas por ROSSLER E MOBERLY (1972) e GOSNELL e KOENIG (1972), foi anotada por LONSDALE E GOSNELL (1976) co mo devido às flutuações na umidade da cana e acúmulo de maté ria seca.

Ainda estudando a influência da idade e da sa fra sobre o desenvolvimento vegetativo e qualidade da cana-de-açúcar, LONSDALE E GOSNELL (1976) observaram que o açū car estimado recuperável por cento de cana aumenta rapidamen te até 12 e 13 meses, devido ao decréscimo na umidade e au mento na sacarose : cana e pureza.

Na Austrália, LEVERINGTON et alii (1978) rea

lizaram um ensaio para avaliar a influência da época de co Theita na produtividade da cana-de-açúcar. Os dados mostra ram que enoora a produtividade de colmos tenha apresentado diferença significativa entre as épocas, os mesmos não mos traram qualquer tendência durante a safra. Entretanto, assim como na Âfrica do Sul, na Austrália o ponto máximo de-matura ção ocorre no mês de setembro.

A construção de uma destilaria para produção de etanol como combustivel no zimbabwe, enfatizou a necessi dade de se determinar se as técnicas agronômicas usualmente aplicađas à produção de açúcar devem ser alteradas quando a matéria-prima destina-se à produção de álcool, de acordo com CACKETT e RAMPF (1981).. Os autores concluiram que o valor dos açúcares totais fermentesciveis pode ser satisfatoriamen te estimado através dos dados de Brix. Os açúcares totais (AT) foram calculados pela expressão: $A T=(p o l / 0,95)+$ açúcares redutores, e correlacionados linearmente com os respectivos valores de Brix, obtendo altos coeficientes de regressão. Aplicando as equações nos ensaios em que não dispunham dos valores de açúcares redutores, foi possível com o Brix esti mar os açúcares totais. Desse modo, concluiram que para pro dução dé álcool é aceitável a colheita iniciar dois meses an 
tes da época normal para industrialização para produção de açücar.

Como citado anteriormente, a lavoura canaviei ra é avaliada pela produtividade de colmos ( $t /$ ha) e teor de sacarose ou açúcar recuperável, os quais irão definir a pro dutividade agroindustrial em toneladas de açúcar por hectare. Entretanto, há necessidade de se considerar os aspectos eco nômicos na escolha de variedade, como salientado por Hugot, citado por MIOCQUE (1980).

o custo de produção de cana-de-açúcar para dẹ terminado conjunto de tecnologias é fixo por área, para qual quer variedade, mas os custos da colheita e moagem dependerá da quantidade de matéria-prima obtida por unidade de área. Por este motivo, MIOCQUE (1980) sugere o cálculo de "valor relativo", que leva em considerạ̣ã esses aspectos.

\subsection{Fertirrigação da caṇa-de-açūcar}

A aplicação de altos volumes de restilo (ví nhaça + água de lavagem de cana) nos sulcos de plantio ou na entre-linha de cana-de-açúcar tem sido definido como fertir rigação, isto é, irrigação fertilizada (COPERSUंCAR, 1980a) .

A utilização agrícola da vinhaça como fertili zante foi ponderada por diversos autores, como salientado por ALMEIDA (1952). Entretanto, acreditava-se que a vinhaça in natura, devido ao seu baixo $\mathrm{pH}$, não podia sẹ incorporada aos solos, uma vez que iria reduzir o pH dos mesmos. o pró prio autor reconhece ter contribuido para tal dogma, com a pu blicação de um artigo no.uornal de Piracicaba em 17 de agos to de 1949 onde alertava para os perigos da adição da vinha ça ao solo. Porém, ALMEIDA et alii (1950) apresentaram um trabalho que pode ser considerado como o pioneiro sobre reco męndação e avaliação dos efeitos da vinhaça aplicada ao solo. Em resumo, ALMEIDA (1952) concluiu que, a aplicação de vinhạ 
ça nos solos contribui para: elevar o $\mathrm{pH}$ do so do ou alcalinizando; melhorar suas propriedades fisicas e quí micas; aumentar o p̣oder de embebição para a água; ocasionar maior retenção de sais minerais e, aumentar a microflora do solo.

A única recomendação preconizada por ALMEIDA (1952) que não encontrou posteriormente respaldo foi a dosa gem de 500 a $1.000 \mathrm{~m}^{3} / \mathrm{ha}$ aplicado no início da safra. De acor do com GLÓRIA (1976), esta alta dosagem acarretava a incorpora ção ao solo de altas concentrações de nutrientes que, se não fossem absorvidos pelas plantas, seriam lixiviados para as camadas mais profundas do solo. Ainda, estas altas dosagens propiciavam um grande desenvolvimento vegetativo à cultura e, posteriormente, em períodos de seca verificou-se que as plan tas sentiam demasiadamente o efeitu da estiagem. Para GLÓRIA (1976), estes aspectos não permitiram que a prática se genera lizasse, como era de se esperar.

Durante a safra paulista de 1978/79, 64 usinas com moagem total de 313.800 toneladas de cana-de-açúcar por dia foram avaliadas por COPERSUCAR (1980a). Os residuos polui dores produzidos por essas indústrias correspondem a uma carga poluidora de 3,6 milhões de quilos de DBO (demanda biológica de oxigêniol, dos quais ao redor de $160 \mathrm{mil} \mathrm{Kg}$ de DBO ou $4,4 \%$ são despejados nos leitos dos rios, poluindo as bacias hidro gráficas. Esta carga poluidora corresponde ao esgoto domésti co de uma cidade de 3 milhões de habitantes. Entretanto, se todo o resíduo poluidor destas 64 usinas fosse lançado aos rios, corresponderia à uma população de 63 milhões de pessoas. Este aspecto tem justificado a rígida legisla ção governamental no controle da poluição, conduzindo às usi nas de açúcar e destilarias de álcool a procurarem soluções para disporem de seus resíduos. A aplicação à lavoụra tem si do a forma mais comumente empregada para dispor da vinhaça, o mais poluidor dos resíduos. Quanto a água da lavagem de cana, devido ao seu alto volume, a solução mais prática e eficiente 
tem sido obtida com circuitos fechados ou semi-fechados de tratamento, de acordo com COPERSUCAR (1980a).

A aplicação da vinhaça na lavoura em altos vo lumes vem sendo realizada pela Usina Tamoio, Araraquara - SP, desde 1951, segundo AGUJARO (1979). O resíduo é . aplicado atualmente em dosagens de $180 \mathrm{~m}^{3} / \mathrm{ha}$ quando o teor de potás sio trocável no solo é menor do que $0,5 \mathrm{e} . \mathrm{mg} / 100 \mathrm{~g}$ solo. Em três safras foram obtidos as seguintes produtividades de col mos em toneladas por hectare:

$\begin{array}{lccc}\text { Safra } & 72 / 73 & 73 / 74 & 74 / 75 \\ \text { área irrigada. } & 109 & 96 & 111 \\ \text { área sem viṇhạ̧a } & 88 & 82 & 74 \\ \text { diferença (\%) } & +23,9+17,1 & +50,0\end{array}$

O efeito da vinhaça na produtividade de colmss das soqueiras ( $t /$ ha) é também apresentado por AGUJARO (1979) para toda área colhida na safra 75/76:

$\begin{array}{lcccc}\text { Corte } & 19 & 29 & 39 & 49 \\ \text { com vinhaça ( } t / \text { ha }) & 91 & 89 & 88 & 81 \\ \text { sem vinhaça ( } t / h a) & 87 & 67 & 57 & 48 \\ \text { diferença }(\%) & +4,6 & +32,8 & +54,4 & +68,7\end{array}$.

A vinhaça é aplicada na Usina Tamoio por sul cos de infiltração em áreas próximas da indústria, em solos Latossolo Vermelho-Amarelo, fase arenosa, que representam 40\% das terras, sendo o restante formado na maior parte do solo Latossol Roxo. Segundo AGUJARO (1979), se a comparação fosse feita no mesmo tipo de solo as diferenças seriam maiores. o autor afirmou ainda que a utilização de vinhaça tem contribuí do para a substituição de variedades, dando-se preferência pa ra aquelas ricas em sacarose que possibilitem maior produção de açúcar por unidade de área.

A utilização da vinhaça na lavoura da Usina São José ZL, em Macatuba - SP, teve início com um projeto rea lizado na safra de 1970/71, que previa a irrigação por infil 
tração, como descreveram LORENZETTI e FREITAS (1978). Durante seis anos a vinhaça foi aplicada em área de aproximadamente 100 ha/ano, sendo que após a irrigação com três milhões de li tros de vinhaça diluída em águas residuais por hectare, o so lo era gradeado e plantado com cana-de-açúcar. Entretanto, em virtude das desvantagens do sistema de infiltração os autores cogitaram por aplicação com caminhōes-tanque è por aspersão, sendo este considerado o ideal para as condições da Usina são José ZL e utilizado a partir de 1975.

Os resultados obtidos na safra 77/78 na Usina São José ZL, em função da variedade, sistema de aplicação, cọ te, idade e produtividade de colmos, mostraram que a NA56-79 produziu de 163 a 170 t de colmos/ha no primeiro corte, com aplicação do restilo por aspersão ou sulcos de .. infiltração entre 18 e 20 meses de idade.

Na lavoura da Usina São João, Araras - SP, é utilizado um sistema de irrigação por sulcos de infiltração com restilo, de acordo com descrição feita por ROSSETTO ; et alii (1978). Através de um sistema de recalque são enviados para a lavoura $1.500 \mathrm{~m}^{3}$ de resídúos/hora, que são aplicados na cultura de cana-de-açúcar por sulcos de infiltração, tendo co berto uma área de 1.352 ha na safra 77/78. Cerca de 70\% da vi nhaça produzida pela destilaria anexa da Usina são João é mis turada às águas residuais, principalmente àquela utilizada na lavagem de cana, na proporção de 1:10. Este restilo é aplica do em cana-planta, após quatro ou cinco meses do plantio, atra vés dos sulcos ou em cana soca ém sulcos abertos na entre-li nha logo após a colheita.

ROSSETTO èt alii (1978) apresentaram as prodū tividades de diversas variedades nas safras $76 / 77$ e 77/78, cuㅡ jas médias na área irrigada foram: 111, 99, 97, 94 e 98 tone ladas de colmos/ha, para $019,29,39,49$ e 59 cortes, respec tivamente. 
Os resultados de AGUJARO-(1979), LORENZETTI e

FREITAS (1978) e ROSSETTO et alii (1978) mostraram que a produ ${ }_{n}$ tividade de colmos decresce menos acentuadamente nas áreas fer tirrigadas em comparação com adubação mineral. Por outro lado, - favorecimento do desenvolvimento vegetativo da cultura, devi do às altas dosagens da matéria orgânica e nutrientes, produz uma matéria-prima com menor concentração, de sacarose.

Devido a dificuldade de se comparar áreas com fertirrigação e áreas cultivadas com adubação mineral, somente um trabalho de pesquisa foi localizado na literatura consulta da. SILVA et alii. (1976) realizaram um estudo sobre o comporta mento agroindustrial da cana-de-açúcar em função da fertirriga ção na lavoura da Usina da Pedra, Serrana - SP. Os autores uti lizaram o segundo corte de 16 variedades plantadas em dois tâ Ihões.

Através dos resultados obtidos por SILVA et alii (1976) pode-se constatar que a fertirrigação provocou uma elevação na produtividade de colmos, para todas as variedades. Entretanto, a pol o cana foi igualmente reduzida na área fer tirrigada, provocando um atraso nà maturação e, em alguns ca sos, menor produtividade de pol (sacarose) por hectare. Obser vou-se ainda que a fertirrigação resultou em redução no teor de fibra e elevação na porcentagem de cinzas condutimétricas do caldo das variedades estudadas.

Ainda na lavoura da Usina da Pedra, GLÓRIA e MAGRO (1977) apresentaram um relato dos estudos e experiên cias realizadas na lavoura, visando definir a sistemática para aplicação de resíduos na lavoura. Na safra 74/75 a produção diária de resíduos nessa Úsina era de 35 milhões de litros de águas residuais, $900 \mathrm{mil}$ litros de vinhaça e $130 \mathrm{t}$ de torta de filtro. Até a referida safra, todo este material era misturado na saída da indústria e bombeado para a lavoura. Os resulta dos obtidos em dois talhões uniformes mostraram que a produti vidade média de 4 cortes foi elevada em 15\% pela aplicação do restilo, e sem diferença na pol : cana. 
2.3 Virihaça aplicada com caminhão-tanque

A quase totalidade dos trabalhos de pesquisa pu blicados sobre a utilização da vinhaça como fertilizante da ca na-de-açúcar, tem sido realizados utilizando veículos com tan que para aplicação. Estas pesquisas tem procurado os mais di versos objetivos, como os estudos de complementação da adu bação com nitrogênio, fósforo, realizados por MAGRO e GLÓRIA (1977) e de complementação nitrogenada da adubação com vinhaça efetuadas por SILVA et alii (1981).

- Sendo o Estado de São Paulo o maior produtor na cional de álcool, as pesquisas foram intensificadas na lavoura canavieira paulista, sendo pequena a contribuição de outros Es tados para o assunto. SOBRAL et alii (1981) apresentaram os re sultados obtidos com a fertirrigação de soqueiras da variedade CB45-3 com Vinhaça, na Destilaria Baia Formosa, Baia Formosa RN, e na Usina Cucaú, Rio Formoso - PE. No ensaio realizado com vinhaça proveniente da Destilaria Baia Fromosa foram aplicados $100,200,300$ e $400 \mathrm{~m}^{3}$ vinhaça/ha, o que corresponde a aplica: ção de 70 a $280 \mathrm{~kg}$ de $\mathrm{K}_{2} \mathrm{O} / \mathrm{ha}$. No segundo ensaio, com vinhaça mais concentrada da Usina Cucaú, as doses foram de 50, 100, 150 , e $200 \mathrm{~m}^{3}$ vinhaça/ha, correspondendo a 235 a $940 \mathrm{~kg}$ de $\mathrm{K}_{2} \mathrm{O} / \mathrm{ha}$.

Os resutados obtidos por SOBRAL et alii (1981) mostraram que a vinhaça como fertilizante eleva significativa mente a produtividade de colmos em relação ao tratamento sem adubação. Porém, no ensaio realizado em solo tipo Areia Quartzo za (AQd) com vinhaça proveniente da Destilaria, as parcelas com adubação mineral produziram quase três vezes mais do que as par celas adubadas com o resíduo. No solo tipo Latossol Vermelho Amarelo (LVA) a produtividade de colmos com vinhaça foi do mes mo nível da adubação mineral, porém com tendência decrescente da menor para a maior dosagem, sem diferenças significativas. 
Quanto a pol o cana, os autores não observaram diferenças sig nificativas entre os tratamentos, nos dois tipos de solos, contrariamente ao que se tem obtido no Estado de são Paulo.

Os efeitos da vinhaça como fertilizante sobre a qualidade tecnológica da cana-de-açúcar tem sido normalmen te relatados como decréscimo do teor de-sacarose (pol) da cana-de-açúcar, redução do teor de fibra e elevação do teor de cinzas condutimétricas do caldo. De acordo com

CLARKE (1981), os altos níveis de cinzas no açúcar, especialmente po tássio, tem originado problemas nas refinarias. Entre 30 e $50 \%$ das cinzas do caldo são devidas ao potássio, o qual for ma um complexo com a sacarose retendo-a na solução, diminuin do a sua cristalização e, consequentemente, a recuperação da seção do cozimento. Para o autor, a principal fonte de potás sio é a aplicação de excesso de aরuio potássico na lavoura, com a esperança de elevar os teores de sacarose.

o alto teor de potássio na vinhaça to:na o re síduo um adubo potássico, sendo a dosagem do líquido controla da pelo teor deste nutriente. Assim, os trabalhos experimen tais com vinhaça tem se preocupado com a quantidade de $\mathrm{K}_{2} \mathrm{O}$ aplicada no solo, bem como o teor de cinzas no caldo da cana-de-açúcar.

SIIVA et alii (1978) estudaram a adubação da soqueira (30 corte) da variedade CB41-14 com vinhaça aplicada por caminhão-tanque em solo Latossol Vermelho Escuro na Usina São Geraldo, Sertãozinho - SP. As dosagens do residuo foram relativamente baixas, de 15 a $60 \mathrm{~m}^{3} / \mathrm{ha}$, o que correspondeu à aplicação de 36 a $144 \mathrm{~kg}$ de $\mathrm{K}_{2} \mathrm{O} / \mathrm{ha}$. Os resultados obtidos pe los autores mostraram redução significativa na pol : cana, e elevação também significativa das cinzas do caldo e $t$ colmos/ /ha. A produtividade de pol por hectare elevou-.se não signifi cativamente de $9,0 \mathrm{t} / \mathrm{ha}$ na adubação mineral para $11,1 \mathrm{t} / \mathrm{ha}$ na dosagem de $60 \mathrm{~m}^{3} / \mathrm{ha}$ ou $144 \mathrm{~kg}$ de $\mathrm{K}_{2} \mathrm{O} / \mathrm{ha}$.

Provavelmente, devido ao baixo nível de potássio 
adicionado ao solo, $144 \mathrm{~kg}$ de $\mathrm{K}_{\mathbf{2}} \mathrm{O} / \mathrm{ha}$ na maior dosagem de ví nhaça e $120 \mathrm{~kg}$ de $\mathrm{K}_{\mathbf{2}} \mathrm{O} / \mathrm{ha}$ no adubo mineral, SILVA et alii, não obtiveram grandes efeitos depressivos sobre a qualidade da matéria-prima, como relatado por STUPIELLO et alii (1977). Estes autores trabalharam com vinhaça proveniente de mosto de melaço, portanto, com altos níveis de $\mathrm{K}_{\mathbf{2}} \mathrm{O}$, aplicada por cami nhão-tanque no 3 ? corte da variedade CB41-76 em solo Podzóli co Vermelho Amarelo, variação Laras, na Usina Costa Pinto, Pi racicaba - SP. Os dados obtidos na colheita do ensaio mostra ram que a produtividade de colmos foi elevada em 30\% entre a testemunha absoluta e o tratamento com $210 \mathrm{~m}^{3}$ de "vinhaça/ha $\left(1.430 \mathrm{~kg}\right.$ de $\left.\mathrm{K}_{2} \mathrm{O} / \mathrm{ha}\right)$, mas a pol \% cana foi reduzida em 23\% en tre estes tratamentos, fazendo com que a produtividade de pol permanecesse em $8,5 \mathrm{t} / \mathrm{ha}$. Não foi incluído um tratamento com adubação rineral, impedindo comparações com o sistema tradi ċonal de adubação da soqueira: da cana-de-açúcar.

Devido ao seu teor de sais, a aplicação siste mática da vinhaça como fertilizante poderia conduzix a uma sa linização do solo, com reflexos negativos para o desenvolvi mento da cana-de-açúcar. Esta premissa foi pesquisada por COPERSUCAR (1980c) através da repetição do ensaio no mesmo lo cal por três anos consecutivos. O estudo da composição quími ca do solo nos três anos de duração do ensaio mostrou que so mente o potássio trocável elevou-se linearmente com as dosa gens de vinhaça, prinçipalmente logo após as aplicações do re síduo. O nível de potássio no solo após a última colheita in dicou para COPERSUCAR (1980c) que, provavellmente, um novo plan tio no local dispensaria a adubação potássica nas parcelas que vinham recebendo altas dosagens do restilo. Os valores médios de três colheitas indicaram que a produtividade de col mos aumentou entre 0 e $90 \mathrm{~m}^{3} / \mathrm{ha}$, porém, sem acréscimos signi ficativos a partir de $90 \mathrm{~m}^{3} /$ ha até $180 \mathrm{~m}^{3} / \mathrm{ha}$. Entretanto, o rendimento de açúcar recuperável decresceu quase que linear mente de 111,4 para $97,8 \mathrm{~kg} / \mathrm{t}$ cana, com 0 aumento da dosagem 
de vinhaça entre zero e $180 \mathrm{~m}^{3} / \mathrm{ha}$.

A produção de álcool por via fermentativa em grandes volumes é realizada somente no Brásil, razão pela qual os trabalhos com vinhaça não são comuns em outros paí ses. Na India, BAJPAI e DUA (1972) pesquisaram a utilização de vinhaça diluída 20 vezes, comparada com sulfato de amônio. Embora tenham empregado dosagem do restilo correspondendo a aṕlicação de até $300 \mathrm{~kg}$ de $\mathrm{N} / \mathrm{ha}$ e $2.400 \mathrm{~kg}$ de $\mathrm{K}_{2} \mathrm{O} / \mathrm{ha}$, não notaram efeito depressivo sobre a qualidade de matéria-prima quando comparada com adubação mineral. Por outro ł̦ado, os resultados mostraram redução na produtividade de colmos com a maior dosagem. 
3. MATERIAIS: E MÉTODOS

3.1 Delineamento experimental

Foram instalados dois ensaios, em taj.hões pró ximos, com as mesmas variedades, sendo um em ārea fertirriga da e a outra sem fertirrigação.

As parcelas foram distribuidas no esquemą de blocos ao acaso, com seis variedades e quatro repetições por ensaio, sendo cada parcela composta de cinco sulcos e de com primento variável, com área total de acordo com a Tabela 1.

\subsection{Instalação e épocas}

O experimento foi conduzido em terras pertencen tes à Usina São João, Araras - SP, na Fazenda Jardim.

O plantio foi efetuado em 24 e 25 de fevereiro de 1978 para colhej.ta após 18 meses, no sistema tradicional do Estado de São Paulo, sendo as socas colhidas sempre com 12 meses após o último corte.

o solo da área do ensaio foi classificado como pertencente ao grupo Latossol Vermelho Escüro - orto, e vem sendo cultivada com a cana-de-açúcar há vấrios anos. 
Tabela 1. Area total das parcelas $\left(\mathrm{m}^{2}\right)$

\begin{tabular}{|c|c|c|c|c|c|c|c|}
\hline \multirow{3}{*}{ Blocos } & \multicolumn{7}{|c|}{ Tratamentos - Variedades } \\
\hline & CB40-13 & CB41-76 & CB47-355 & IAC48/65 & IAC52/150 & NA56-79 & Média \\
\hline & \multicolumn{7}{|c|}{ (Área fertirrigada) } \\
\hline$I$ & 1.309 & 1.312 & 1.295 & 1.292 & 1.298 & 1.306 & 1.302 \\
\hline II & 1.267 & 1.288 & 1.284 & 1.278 & 1.281 & 1.270 & 1.278 \\
\hline III & 1.253 & 1.246 & 1.242 & 1.260 & 1.256 & 1.250 & 1.251 \\
\hline IV & 1.222 & 1.218 & 1.232 & 1.239 & 1.228 & 1.225 & 1.227 \\
\hline \multirow[t]{2}{*}{ Média } & 1.263 & 1.266 & 1.263 & 1.267 & 1.266 & 1.263 & 1.265 \\
\hline & \multicolumn{7}{|c|}{ (Área sem fertirrigação) } \\
\hline$I$ & 1.218 & 1.077 & 1.009 & 1.265 & 951 & 1.143 & 1.111 \\
\hline II & 1.335 & 1.644 & 1.537 & 1.400 & 1.474 & 1.601 & 1.499 \\
\hline III & 1.037 & 1.000 & 874 & 916 & 845 & 958 & 938 \\
\hline$I^{-}$ & 965 & 896 & 947 & 882 & 924 & 861 & 913 \\
\hline Média & 1.139 & 1.154 & 1.092 & 1.116 & 1.049 & 1.141 & 1.115 \\
\hline
\end{tabular}

o solo foi preparado com uma gradeação pesa da e uma leve seguidas da subsolagem e, novamente, gradeá ção pesada e leve com calagem intermediária.

o plantio foi executado com tráfego de cami nhões dentro dos sulcos, distribuição normal, picação das mudas e cobertura mecânica dos toletes. As plantas dani nhas foram controladas por mistura de ametrina e 2,4-D em pré-emergência. 
Todas as operações agrícolas mecanizadas e ma nuais foram executadas pela Usina são João, dentro de seu es quema normal de trabalho. Assim, na instalação do experimen to, o plantio não foi realizado com contagem de gemas por me tro linear ou adubação manual, devido ao tamanho das parcelas.

\subsection{Variedades}

As variedades incluidas no estudo foram esco lhidas por serem as mais representativas no Estado de são Paulo, de acordo com os levantamentos do IAA/PLANALSUCAR (1979, 1980 e 1981).

Algumas caracteristicas agroindustriais das seis variedades escolhidas para o experimento, de acordo com definições apresentados por BASSINELLO (1975), BASSINELLO et alii (1976) e SEGALLA e TOKESHI (1981), são apresentados a se guir:

CB40-13: esta variedade foi muito cultivada de vido à sua maturação precoce, altos teores de sacarose e por não florescer normalmente, chegando a ocupar $29 \mathrm{mil}$ hectares de cultivo em 1978 no Estado de São Paulo, segundo IAA-PLANALSUCAR (1979). Apresenta boa produtividade de colmos na cana-planta e regular nas socas. Entretanto, devido a sua al ta suscetibilidade ao mosaico e à broca do colmo, exigência quanto à fertilidade natural dos solos e, principalmente, por não ser uma variedade rústica para as condições de trabalho da lavoura canavieira, vem sendo parcialmente eliminada, dei xando de figurar entre as 10 mais cultivadas.

CB41-76: esta variedade chegou a representar quase 50\% da lavoura paulista de cana-de-açúcar em 1972, de acordo com BRIEGER (1978). Alguns a consideram de maturação média, com teor regular de sacarose, porém é uma variedade de baixo rendimento de açúcar em relação às novas variedades ou quando comparada à NA56-79. Sob condições ideais de cultivo 
em solos férteis pode competir com outras variedades quanto à produtividade de colmos, mas em termos de sacarose é sem pre inferior. Por não florescer normalmente, apresentar re sistência ou tolerância às principais doenças da cana-de-açū car e com brotação regular nas soqueiras, aliado ao fato de não haver outras opções varietais na época, sua área cultiva da cresceu bastante no Estado de são Paulo, estando ainda ho je entre as mais cultivadas. Com a expansão da cultura para áreas menos férteis e a entrada de NA56-79 e IAC52/150, seu cultivo passou a declinar.

CB47-355: o cultivo desta variedade deve 'ser restrito a solios com boa capacidade de retenção de umidade, devido a suá relativa alta exigência em termos de solo. A sua curva de maturação pode ser classificada como de média para tardia, com teores médios de sacarose. Pode ser colhida aprio setembro por não florescer ou chochar. o porte ereto, baixo teor de fibra, em torno de 10 a 11\%, despalha fácil, facili tam sua colheita. É resistente ao mosaico, carvão, escaldadu ra, raquitismo e podridões.

IAC48/65: atualmente, esta variedade encontra-se entre ás cinco mais cultivadas no Estado de São Paulo, de vido ao fato de não ser muito exigente quanto à fertilidade na tural do solo. Sua expansão tem sido limitada pelo floresci mento intenso, seguido do chochamento ("isoporização") do col mo, juntamente com os teores médios do teor de sacarose e pe riodo útil de industrialização curto. A IAC48/65 continua a ser cultivada por ser resistente as principais doenças dacul tura, porém cedendo área para as novas variedades.

IAC52/150: a terceira variedade mais cultivada no Estado de São Paulo em 1980 ocupava uma área ao redor de 110 mil hectares. Assim como a IAC48/65, a IAC52/150 não é muito exigente em fertilidade natural dos solos, e como aque la variedade, floresce intensamente com a consequente "isopo rização" dos colmos, embora apresente maior teor de sacarose 
em meados da safra. Por estes aspectos e por ser resistente principalmente ao mosaico e ao carvão, sua área cultivada vem se expandindo, mas será limitada pelo seu florescimento.

NA56-79: esta variedade foi introduzida no Es tado de São Paulo em meados da década de 70, ocupando atual mente ao redor de 50\% da lavoura de cana-de-açúcar, segundo COPERSUCAR (1982b). Provalmente, nenhuma outra variedade foi multiplicada em escala tão grande como a NA56-79. Isto ocor reu devido principalmente a sua maturação extremamente preco ce, altos teores de sacarose, produtividade elevada de colmos tanto em cana-planta como em soqueiras e rusticidade sob con dições normais de cultivo. Mesmo em solos arenosos ou de bai xa fertilidade tem-se cultivado com sucesso esta variedade, embora seja um pouco exigente em fertilidade, principalmente quando comparada com as novas variedades como a SP70-1143, de acordo com COPERSUCAR (1982a). A NA56-79 tem florescido em certos anos agrícolas, porém sem a intensidade da IAC48/65 ou IAC52/150. Por ser de resistência moderada ou suscetível ao carvão e mosaico, e pelas novas opções varietais, sua área de plantio tende a se estabilizar e a seguir, declinar. o cresci mento da área de NA56-79 e IAC52/150 atesta a preferência dos produtores por variedades ricas e precoces, porém com boa pro dutividade agricola mesmo em solos de menor fertilidade natu ral.

\subsection{Fertirrigação e adubações}

O sistema de trabalho para fertirrigação foi aquele descrito por ROSSETTO et alii (1978), e normalmente empregado pela Usina São João - Araras, SP.

Na área fertirrigada foi aplicado monofosfato de amônio na dosagem de $300 \mathrm{Kg} / \mathrm{ha}$, sendo a fertirrigação efe tuada seis meses após o plantio. O restilo (vinhaça com água de lavagem de cana) foi conduzido pelos sulcos de plantio, $\mathrm{Na}$ 
cana-soa, após a colheita foi realizado o enleiramento do pa lhiço, subsolagem e cultivo com grades de discos na entre-lí nha de cana. A seguir, foram abertos sulcos com o implemento "bico de pato" por onde se escoou a mistura do restilo.

$\mathrm{Na}$ segunda soca (3⿻ corte) foram utilizados tú , bos plásticos flexíveis, o que permitiu a aplicação de maior volume de resíduos. As dosagens nos três corte's são apresenta das na Tabela 2 .

Tabela 2: Período ảe aplicação e dosagens do restilo nos três cortes do ensaio fertirrigação

\begin{tabular}{|c|c|c|c|c|}
\hline Péríodo de & Aplicação & Dias & $\begin{array}{c}\text { Corte } \\
\ldots \ldots\end{array}$ & $\begin{array}{r}\text { Dosagem } \\
\left(\mathrm{m}^{3} / \mathrm{ha}\right)\end{array}$ \\
\hline $27 ; 09$ & $17 / 11 / 78$ & 13 & 10 & 2.800 \\
\hline $14 / 10$ & $14 / 11 / 79$ & 3 & 29 & 1.300 \\
\hline $07 / 10$ & $26 / 10 / 80$ & 19 & 30 & 14.100 \\
\hline
\end{tabular}

Neste sistema não há possibilidade de se conhe cer antecipadamente o volume de restilo a ser aplicado, como salientado por GLORIA (1976). Isto porque, para se poder irri gar todas as partes do talhão, há necessidade de se efetuar uma irrigação contínua, sendo o volume dependente das condi ções do terreno, principalmente umidade, textura e preparo dos sulcos.

A adubação da área sem fertirrigação foi reali zada com a formulação 05-30-20 na dosagem de $500 \mathrm{Kg} / \mathrm{ha}$, apli cados no sulco de plantio. A adúbação de cobertura da cana-planta foi realizada com uréia (50 kg/ha) e cloreto de potás sio $(80 \mathrm{~kg} / \mathrm{ha})$.

Nas soqueiras foi utilizada a formulação 15-09-18 com dosagem de $500 \mathrm{~kg} / \mathrm{ha}$, e cobertura com uréia $\mathrm{kg} / \mathrm{ha}$ ) e cloreto de potássio (85 kg/ha). 


\subsection{Amostragens e avaliações}

\section{a - Solo}

Para a caracterização do local foram coletadas amostras compostas de solo na área fertirrigada e sem fertir rigação. A Tabela 3 apreserita os resultados de: $\mathrm{pH}$, porcenta gem de carbono e saturação de bases, e.mg/100 g de solo de $\mathrm{PO}_{4}^{3+}, \mathrm{K}^{+}, \mathrm{Ca}^{2}+, \mathrm{Mg}^{2+}, \mathrm{Al}^{3+}$ e $\mathrm{CTC}_{i}$ de acordo com os métodos descritos por CATANI e JACINTHO (1974).

Tabela 3. Resultados da análise química do solo coletado de 0 a $30 \mathrm{~cm}$ de profundidade, antes do plantio da ca na-de-açúcar

\begin{tabular}{|c|c|c|c|c|}
\hline Determina ção & 1 & 2 & $\begin{array}{c}\text { Amostra } \\
\text { nnédia }\end{array}$ & 3 \\
\hline $\mathrm{pH}$ & 5,70 & 5,65 & 5,68 . & 5,55 \\
\hline Carbono $(\%)$ & 2,09 & 2,19 & 2,14 & 2,09 \\
\hline Aluminio livre $\left(\mathrm{Al}^{+++}\right)$ & 0 & 0 & 0 & 0 \\
\hline Fósforo $\left(\mathrm{PO}_{4}^{---}\right)$ & 0,24 & 0,24 & 0,24 & 0,23 \\
\hline Potássió $\left(\mathrm{K}^{+}\right)$ & 0,14 & 0,13 & 0,14 & 0,65 \\
\hline Cálcio $\left(\mathrm{Ca}^{++}\right)$. & 4,90 & 5,10 & 5,00 & 4,10 \\
\hline Magnésio $\left(\mathrm{Mg}^{++}\right)$ & 1,30 & 1,30 & 1,30 & 1,20 \\
\hline Hidrogênio $\left(\mathrm{H}^{+}\right)$ & 5,44 & 5,68 & 5,56 & 6,64 \\
\hline Indice de Saturação & 53,82 & 53,48 & 53,65 & 47,25 \\
\hline Soma bases trocáveis & 6,34 & 6,53 & 6,44 & 5,95 \\
\hline Capacidade troca catiônicia & $11,7.8$ & 12,21 & 12,00 & 12,59 \\
\hline
\end{tabular}

1 e 2 = ārea não fertirrigada

3 = área fertirrigada 


\section{b. Restilo}

O réstilo (mistura de vinhaça com água de lavạ gem de cana) foi amostrado continuamente durante a irrigação do talhão, no ponto de entrada do efluente. No restilo foi de terminado: nitrogênio $(\mathrm{N})$, fósforo $\left(\mathrm{P}_{2} \mathrm{O}_{5}\right)$, potássio $\left(\mathrm{K}_{2} \mathrm{O}\right)$, cálcio (CaO) e magnésio ( $\mathrm{MgO}$ ) em $\mathrm{kg} / \mathrm{m}^{3}$ e medição do $\mathrm{pH}$, de. acordo com GLORIA et alii (1972) .

o volume de restilo foi medido pelo sistema de vertedores retangulares, tipo Bazin, com 1,2 m de largura, co locado no canal principal na entrada e na saída do restilo no talhão.

A composição média do restilo é apresentada na Tabela 4, assim como a quantidade risultante dos três macronu trientes por hectare, considerando o volume médio aplicado.

Tabela 4 . Composiçäu média em $N, \mathrm{P}_{2} \mathrm{O}_{5}$ e $\mathrm{K}_{2} \mathrm{O}$ da mistura de ví nhaça com águas residuais, e dosagem de nutrientes aplicados nos tratamentos fertirrigados.

\begin{tabular}{|c|c|c|c|c|c|c|c|c|}
\hline Corte & Ano & & $\mathrm{N}$ & $\begin{array}{l}\mathrm{P}_{2} \mathrm{O}_{5} \\
\mathrm{q} / \mathrm{m}^{3} .\end{array}$ & $\mathrm{K}_{2} \mathrm{O}$ & $N$ & $\begin{array}{c}\mathrm{P}_{2} \mathrm{O}_{5} \\
\mathrm{~kg} / \mathrm{ha}\end{array}$ & $\mathrm{K}_{2} \mathrm{O}$ \\
\hline 19 & 1978 & & 104 & 9 & 400 & 289 & 25 & .1 .114 \\
\hline 20 & 1979 & . & 130 & 20 & 260 & 164 & 25 & 329 \\
\hline 30 & 1980 & & 82 & 8 & 210 & 1.156 & 113 & 2.961 \\
\hline
\end{tabular}

c Cana-de-açúcar

A cana-de-açúcar foi amostrada mensalmente a partir do mês de maio, tanto na cana-planta como nas soquei ras. Em cada parcela, foram coletadas 3 amostras, composta ca da uma de 10 colmos colhidos em seguida no mesmo sulco em 
três pontos ao acaso.

Cada amostra foi preparada em desintegrador ti. po forrageira adaptado para análise de cana-de-açúcar. o cal do foi extraído pela prensagem de $500 \mathrm{~g}$ de cana desintegrada e homogeneizada em prensa hidráulica automatizada com pressão constante de $240 \mathrm{~kg} / \mathrm{cm}^{2}$ por um minuto, segundo metodologia proposta por TANIMOTO (1964).

No caldo extraído, determinou-se: Brix refra tométrico, pol pelo método de Schmitz sem diluição, açúcares redutores por oxiredutimetria de acordo com o método de LANE e EYNON, açúcares totais após inversão da sacarose do caldo segundo WALKER e titulação por oxiredutimetria, cinzas condu timétricas e fósforo inorgânico $\left(\mathrm{P}_{2} \mathrm{O}_{5}\right)$, segundo método GOMORI conforme metodologia descrita por COPERSUCAR (1980b).

Com o peso do bagaço da prensa, úmido e seco, e o Brix do caldo extraído calculou-se a fibra por cento de cana, de acordo com tANIMOTO (1964).

Os resultados de Brix e pol por cento de caldo foram transformados em porcentagem de cana utilizando as fór mulas desenvolvidas por STURION e FERNANDES (1979). Para os açúcares totais empregou-se os mesmos coeficientes de Brix.

o peso do bagaço da prensa (úmido) permitiu o cálculo do caldo extraído por cento de cana.

Utilizando os parâmetros: pol : cana, pureza e fibra o cana foi calculado o açúcar teórico recuperável utí zando a fórmula proposta pela COPERSUCAR (1978) e, posterior mente, modificada por COPERSUCAR (1980b).

$A T R=(10 \cdot S-0,76 \cdot F-6,9)\left(\frac{5}{3}-\frac{200}{3 . P}\right)$

Onde:

$$
\begin{aligned}
& \text { ATR }=\text { açúcar teórico recuperável (Kg/t cana); } \\
& \mathrm{S}=\text { pol \% cana; } \\
& \mathrm{F} . \quad \text { fibra \% cana; } \\
& \mathrm{P} \quad \text { pureza. }
\end{aligned}
$$


o álcool provável direto, em litros por tonela da de cana, foi calculado a partir dos açúcares totais o cana e fibra : cana, com a fórmula desenvolvida por COPERSUCAR (1979), e adaptada pela inclusão de fibra na equação.

$\mathrm{EPD}=(5,246 \cdot \mathrm{AT}-0,472 \cdot \mathrm{F})$.
Onde
$\mathrm{EPD}=$ álcool provável direto $(1 / \mathrm{t}$ de cana $) ;$
$\mathrm{AT}=$ açúcares totais \% cana; $\mathrm{e}$
$\mathrm{F} \quad$ fibra $\%$ cana.

\subsection{Colheita do experimento}

o experimento foi colhido sempre no mês de se tembro, proporcionando 18 meses de desenvolvimento para a ca na-planta e 12 meses para a cana-soca.

Os talhões com e sem fertirrigação foram quei mados para auxiliar a despalha, no dia anterior à colheita. o corte manual e o carregamento mecânico foi executado de acordo com o sistema de trabalho da Usina São João - Araras $\mathrm{SP}$.

Em cada parcela foram colhidos 5 sulcos no com primento total do talhão. A pesagem dos colmos foi realizada na balança da Usina São João, pela pesagem das cargas colhị das em cada parcela.

Na colheita, além dos parâmetros determinados mensalmente, foram obtidos: a produtividade de colmos ( $t / h a)$, de açúcar ( $t / h a)$ e de álcool (m³/ha).

As colheitas deverão ser efetuadas até a refor ma e o novo plantio de área fertirrigada. Na área sem fertix rigação, onde se prevê um menor número de cortes, deverá ser realizado novo plantio com as mesmas variedades e mesmo deli neamento experimental. Desse modo, estima-se em 8 a 9 anos a duração deste experimento, sendo incluído neste trabalho so mente os dados obtidos nos 3 primeiros corţes. 


\section{RESULTADOS E DISCUSSÖES}

Devido ao sistema de aplicação da vinhaça diluí da na água residual da lavagem de cana (restilol) através de sulcos de infiltração, isto é, fertirrigação, torna-se impra ticável a instalação de um experimento que inclua parcelas com e sem fertirrigação. Pór este motivo, esta variável foi sepa rada em dois ensaios localizados em áreas próximas, -- porēm isolados. Assim, a discussão dos resultados deve ser efetuada separadamente.

\subsection{Curvas de maturação}

As curvas de maturação das seis variedades estü dadas foram analisadas somente em função do açúcar teórico re cuperável. (ATR) uma vez que este parâmetro da qualidade tec nológica da cana-de-açúcar inclui três importantes variáveis: pol : cana, fibra \% cana e pureza. Os dados obtidos foram ana lisados de forma a se definir o manejo adequado para cada va riedade com ou sem fertirrigação.

Os resultados médios dos quatro blocos para ca da variedade foram utilizados para o cálculo de equações qua dráticas da forma: $y=a+b x+c x^{2}$, onde $\dot{y}$ representa o ATR e $x$ os meses (de 1 a 5 ). A Tabela 5 mostra os valores do coe 


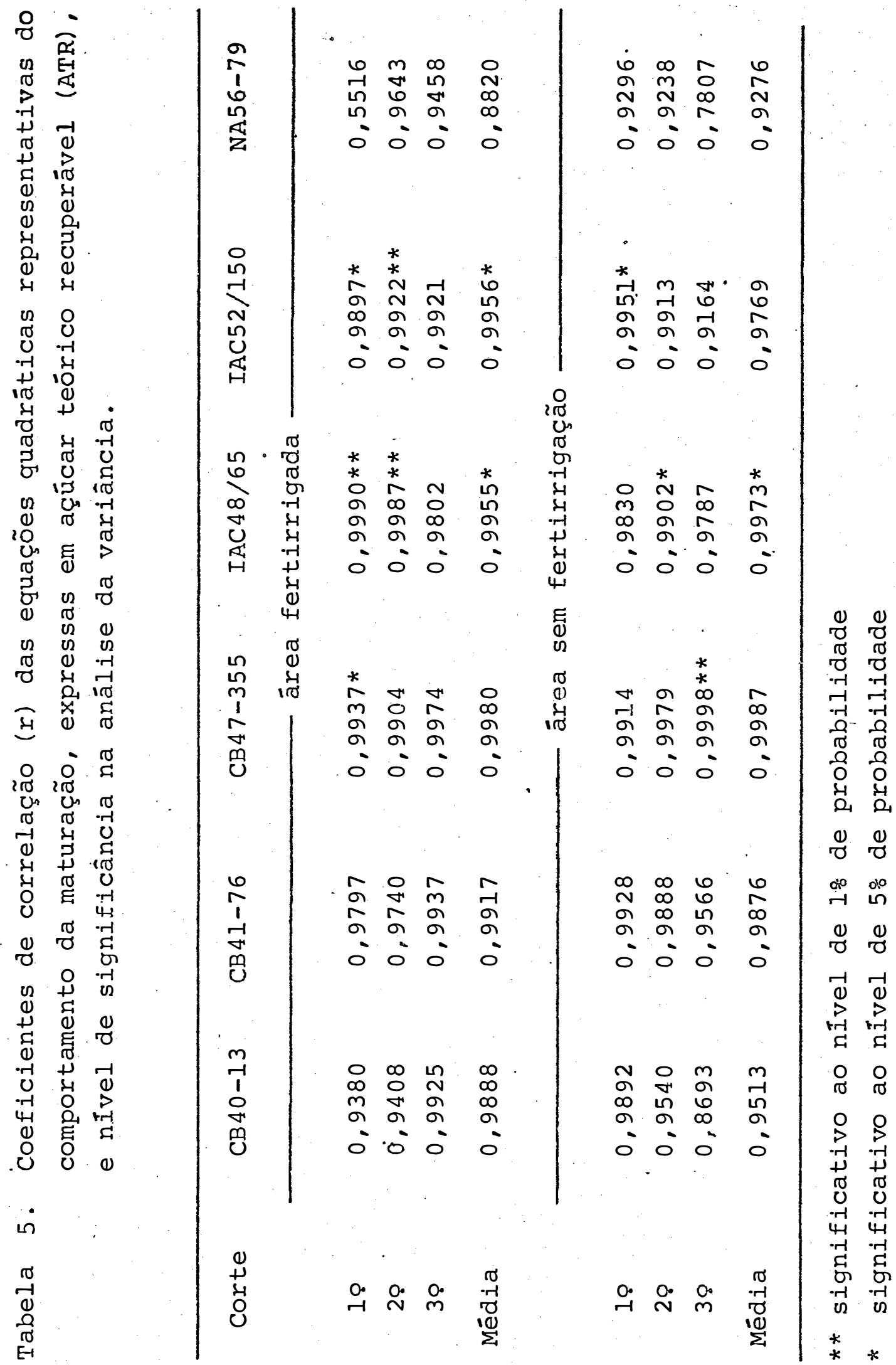


ficiente de correlação para as seis variedades nas

āreas com e sem fertirrigação.

Como se pode notar, somente onze equações de um total de 48 apresentaram significância para a correlação quadrática. Isto se deve provavelmente ao fato de terem sido - utilizados somente cinco pontos no cálculo da equação. As cur vas de maturação. de algumas variedades determinadas por GOSNELL e KOENIG (1972) mostram melhor correlação para os meses de maio a dezembro, embora os autores não tenham apresentado os coeficientes de correlação. Por outro lado, é possivel que a equação quadrática não se adapte para algumas variedades.

Os estudos das curvas de maturação da cana-de-açúcar representa o principal sistema de informações para o manejo de variedades de modo a se definir a melhor época da safra para colheita. No caso dé áreas que recebem fertirri gação, torna-se imperativo a determinação das variedades ade quadas para colheita no início da safra, de modo a se liberar estas áreas para aplicação do restilo que está sendo produzi do, como salientado por ROSSETTO et alii (1978).

Diversos fatores afetam o comportamento da ca na-de-açúcar quanto à maturação, sendo o clina, principalmente temperatura atmosférica, precipitação pluviométrica e horas de insolação, os que mostram efeitos mais evidentes (LONSDALE e GOSNELL, 1975). Os dados climáticos para a região do ensaio estão na Tabela 6 , para o período de coleta dos dados.

\section{a . Area fertirrigada}

O alto nivel de nutrientes, principalmente po tássio e nitrogênio (Tabela 4), matéria orgânica e água, aplj cados com o restilo afetaram sensivelmente a maturação das variedades estudadas. Somando-se o volume de restilo aplicado (Tabela . 2) à precipitação pluviométrica (Tabela 6) em $\mathrm{m}^{3} / \mathrm{ha}$, obtém-se $22.120 \mathrm{~m}^{3} / \mathrm{ha}, 12.278 \mathrm{~m}^{3} /$ ha e $25.656 \mathrm{~m}^{3} / \mathrm{ha}$, para o pri 
Tabela 6 . Dados meteorológịcos observados na Estação Ex oerimental de Araras - SP (IAA - Planalsucar)

\begin{tabular}{|c|c|c|c|c|c|}
\hline \multirow{2}{*}{ Meses } & \multicolumn{3}{|c|}{ Temperaturas $\left({ }^{\circ} \mathrm{C}\right)$} & \multirow{2}{*}{$\begin{array}{c}\text { chuva } \\
(\mathrm{mm})\end{array}$} & \multirow{2}{*}{$\begin{array}{c}\text { insolaçāo } \\
\text { (horas) }\end{array}$} \\
\hline & máx: & min. & méd. & & \\
\hline $\begin{array}{l}\text { Março } \\
\text { Abril } \\
\text { Maio } \\
\text { Junho } \\
\text { Julho } \\
\text { Agosto } \\
\text { Setenbro } \\
\text { Outubro } \\
\text { Novembro } \\
\text { Dezembro } \\
\text { Janeiro } \\
\text { Fevereiro } \\
\text { Março } \\
\text { Abril } \\
\text { Maio } \\
\text { Junho } \\
\text { Julho } \\
\text { Agosto } \\
\text { Sciembro }\end{array}$ & $\begin{array}{l}29,9 \\
27,7 \\
24,2 \\
23,7 \\
25,2 \\
25,6 \\
27,0 \\
30,5 \\
23,2 \\
28,6 \\
28,5 \\
28,4 \\
30,8 \\
27,5 \\
26,5 \\
22,5 \\
25,8 \\
26,9 \\
26,8\end{array}$ & $\begin{array}{r}16,6 \\
13,6 \\
10,9 \\
9,6 \\
10,0 \\
9,5 \\
12,2 \\
15,5 \\
16,1 \\
16,9 \\
17,4 \\
18,0 \\
17,7 \\
15,3 \\
12,7 \\
7,2 \\
9,7 \\
12,0 \\
30,8 .\end{array}$ & $\begin{array}{l}23,2 \\
20,6 \\
17,5 \\
16,3 \\
17,5 \\
17,5 \\
19,6 \\
23,0 \\
22,1 \\
22,7 \\
22,9 \\
23,2 \\
24,2 \\
21,4 \\
19,6 \\
14,8 \\
17,7 \\
19,4 \\
18,8\end{array}$ & $\begin{array}{r}82,8 \\
56,4 \\
50,9 \\
25,2 \\
73,8 \\
- \\
69,2 \\
93,6 \\
208,6 \\
251,6 \\
75,8 \\
143,0 \\
27,2 \\
95,2 \\
169,2 \\
0 \\
27,4 \\
54,4 \\
121,0\end{array}$ & $\begin{array}{l}188,0 \\
241,0 \\
192,0 \\
225,0 \\
221,0 \\
234,0 \\
208,6 \\
252,3 \\
217,0 \\
266,0 \\
216,0 \\
172,0 \\
230,0 \\
217,0 \\
225,4 \\
228,0 \\
231,0 \\
232,0 \\
196,5\end{array}$ \\
\hline Médias/Totais & 27,0 & 13,2 & 20,2 & i. 655,3 & $4.221,8$ \\
\hline 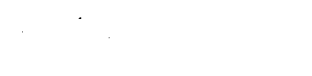 & & \multicolumn{2}{|c|}{29 corte: $1979 / 80$} & & \\
\hline $\begin{array}{l}\text { Outubro } \\
\text { Novembro } \\
\text { Dezembro } \\
\text { Janeiro } \\
\text { Fevereiro } \\
\text { Março } \\
\text { Abril } \\
\text { Maio } \\
\text { Junho } \\
\text { Julho } \\
\text { Agosto } \\
\text { Setembro }\end{array}$ & $\begin{array}{l}29,4 \\
28,5 \\
28,7 \\
28,0 \\
29,8 \\
28,8 \\
27,7 \\
25,3 \\
24,9 \\
23,5 \\
27,6 \\
26,4\end{array}$ & $\begin{array}{r}16,4 \\
16,1 \\
18,3 \\
16,2 \\
17,7 \\
16,1 \\
13,6 \\
12,4 \\
8,5 \\
8,3 \\
11,6 \\
12,9\end{array}$ & $\begin{array}{l}22,9 \\
22,3 \\
23,5 \\
22,2 \\
23,7 \\
22,4 \\
20,6 \\
18,8 \\
16,7 \\
15,9 \\
19,6 \\
19,6\end{array}$ & $\begin{array}{r}87,6 \\
124,2 \\
172,8 \\
226,8 \\
246,8 \\
123,8 \\
150,4 \\
23,0 \\
128,8 \\
0 \\
17,2 \\
103,1\end{array}$ & $\begin{array}{l}237,0 \\
229,0 \\
162,0 \\
219,0 \\
208,0 \\
225,0 \\
223,1 \\
194,0 \\
229,0 \\
219,0 \\
235,0 \\
177,0\end{array}$ \\
\hline Médias/Totais & 27,4 & 14,0 & 20,7 & $1.404,5$ & $2.555,1$ \\
\hline & & \multicolumn{2}{|c|}{39 corte: $1980 / 81$} & & \\
\hline $\begin{array}{l}\text { Outubro } \\
\text { Novembro } \\
\text { Dezembro } \\
\text { Janeiro } \\
\text { Fevereiro } \\
\text { Março } \\
\text { Abril } \\
\text { Maio } \\
\text { Junho } \\
\text { Julho } \\
\text { Agosto } \\
\text { Setembro }\end{array}$ & $\begin{array}{l}29,7 \\
29,1 \\
28,8 \\
28,9 \\
31,1 \\
29,7 \\
28,2 \\
26,0 \\
23,0 \\
23,0 \\
26,5 \\
30,4\end{array}$ & $\begin{array}{r}14,5 \\
13,9 \\
16,5 \\
17,8 \\
14,0 \\
13,4 \\
11,4 \\
10,8 \\
8,0 \\
7,4 \\
11,1 \\
14,9\end{array}$ & $\begin{array}{l}22,1 \\
21,5 \\
22,6 \\
23,3 \\
22,6 \\
21,5 \\
19,8 \\
18,8 \\
15,5 \\
15,2 \\
18,8 \\
22,6\end{array}$ & $\begin{array}{r}98,2 \\
213,0 \\
234,5 \\
285,6 \\
78,5 \\
58,0 \\
42,4 \\
30,6 \\
100,2 \\
10,4 \\
3,6 \\
5,6\end{array}$ & $\begin{array}{l}253,0 \\
267,0 \\
216,0 \\
167,1 \\
266,0 \\
225,7 \\
247,0 \\
256,0 \\
192,0 \\
219,9 \\
233,1 \\
231,0\end{array}$ \\
\hline Méđias/Totais & 28,4 & 12,8 & 20,5 & $1.160,6$ & $2.773,8$ \\
\hline
\end{tabular}


meiro, o segundo e o terceiro corte respectivamente, ou 100,3, 127,9 e $214 ., 2 \mathrm{~m}^{3} \cdot / \mathrm{ha} / \mathrm{mês}$, na mesma ordem.

As curvas de maturação em ATR das Figuras 1 a 4 mostram o comportamento de cada variedade nos três cortes e na média.

No primeiro corte (Figura 1) a variedade CB40-13 sobressaiu-se às demais quanto à maturação, estando em segui da a IAC52/150, confirmando BASSINELLO (1975), . BASSINELLO et alii (1976) e SEGALLA \& TOKESHI (1981). A variedade NA56-79, considerada por estes autores como uma variedade de alto teor de sacarose, apresentou uma curva de maturação os cilante com baixo coeficiente de correlação $(r=0,5516)$ pạ ra a equação quadrática. Admitindo-se um valor mínimo de ATR para maio $=$ junho, somente as três variedades citadas ante riormente poderiam ser colhidas para industrialização e, des se modo, liberar a ārea para nova fertirrigação das sođ̣ueiras.

o desenvolvimento da primeira soca ocorreu em um período de menor precipitação pluviométrica que o ano ante rior (1978/79) nos mesmos meses (outubro à setembro), propi ciando ưma melhor matúração da cana-de-açúcar. As curvas de maturação do segundo corte (Figura 2) mostram um comportamen to semelhante para a CB40-13, IAC52/150 e NA56-79, com esta ültima mostrando valores de ATR um pouco superiores à primei ra. A IAC52/150 sobressaiu-se às outras duas em julho e agos to, estando em declinio em setembro, como observado no primei ro corte, provavelmente devido ao florescimento. Na época de colheita as curvas de maturação destas três variedades tende ram a se igualar, sendo alcançadas pela CB47-355, uma variedą de normalmente recomendada para colheita em setembro ( BASSI NELLO, 1975). A IAC48/65 resultou uma curva de maturação in termediária, embora com baixos valores de ATR. A variedade CB41-76 não repetiu a curva de maturação da cana-planta, ou seja, apresentou valores de ATR extremamente baixos durante 


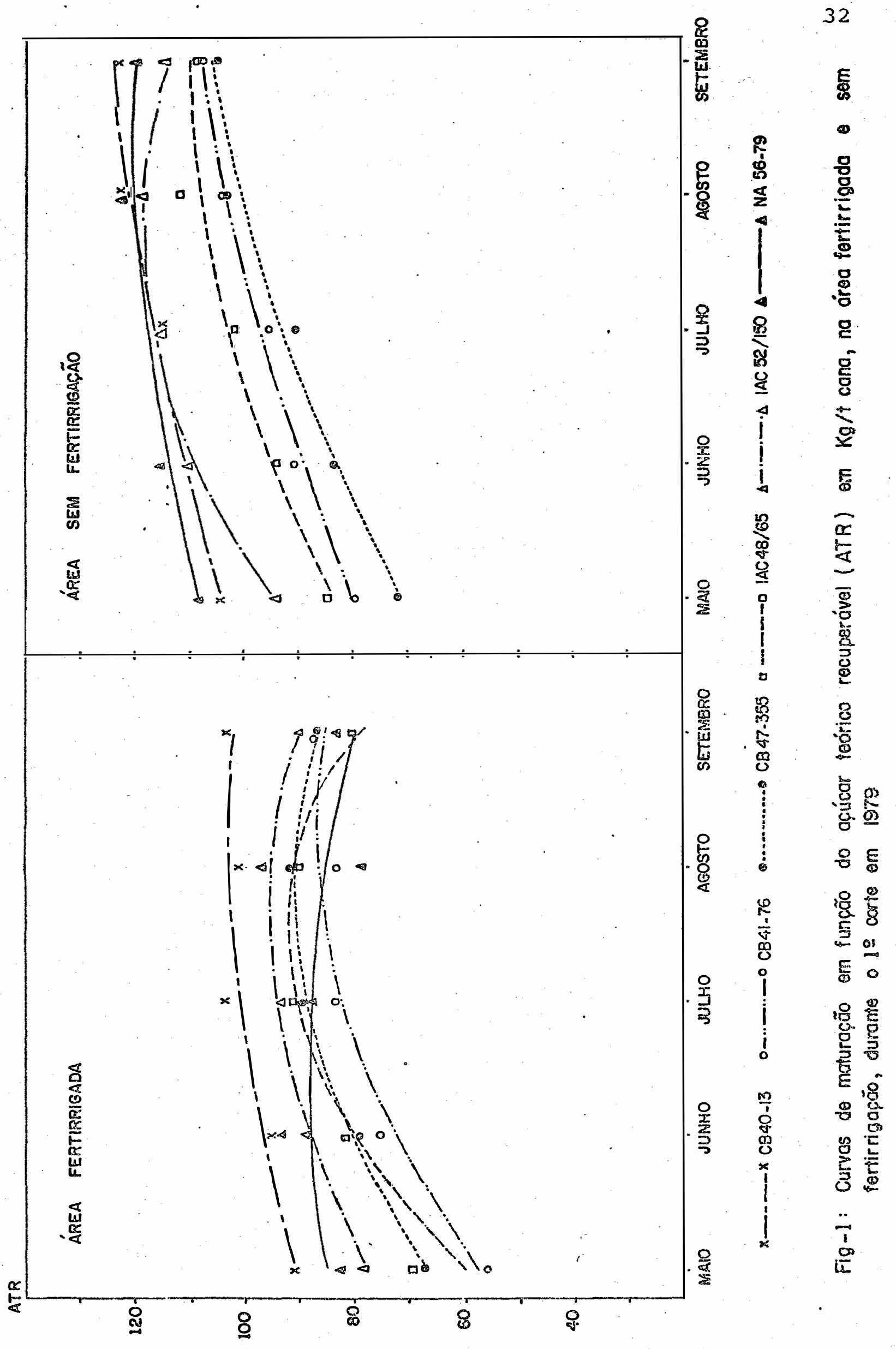




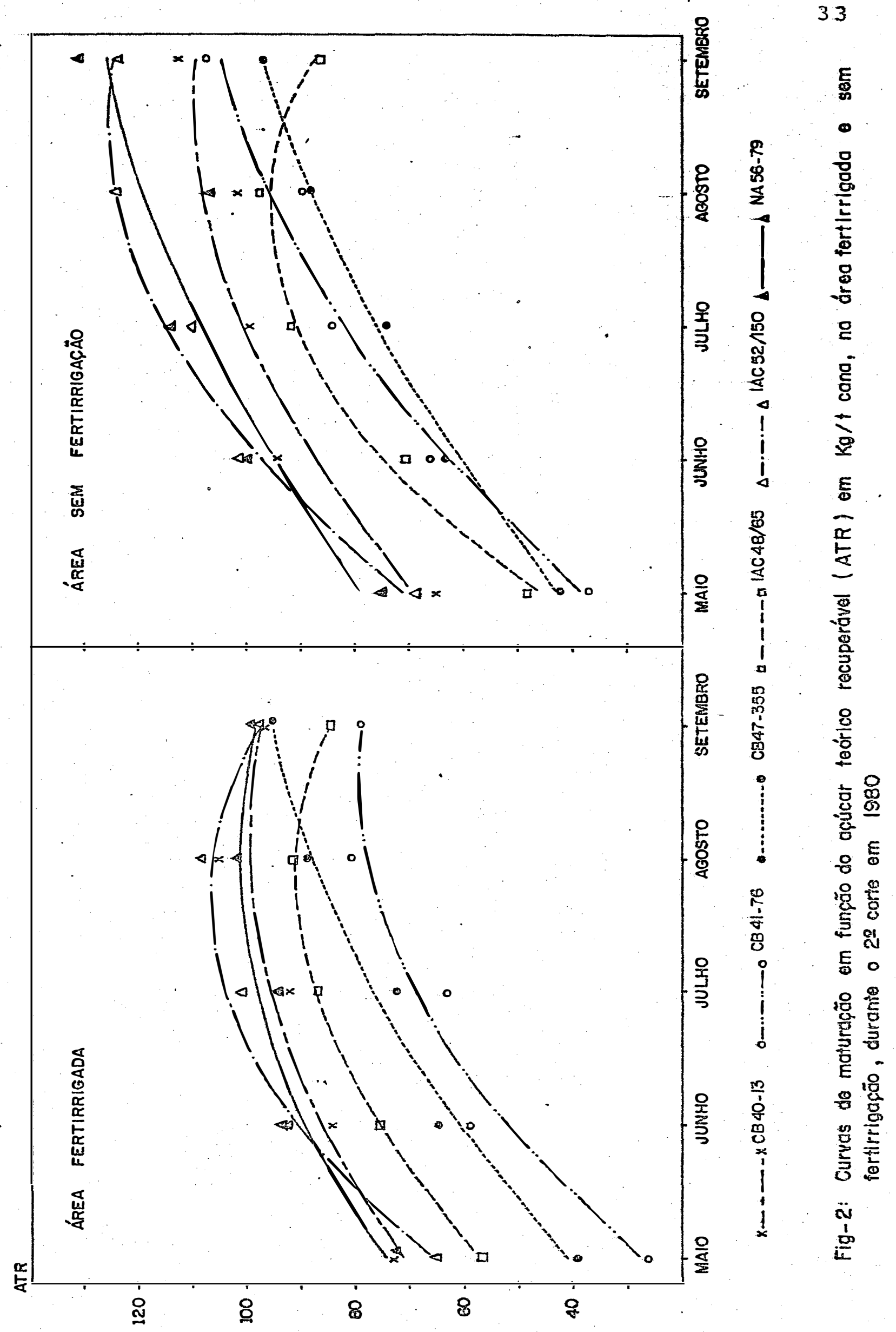


os cinco meses de amostragem do 29 corte.

No terceiro corte (Figura 3) repetiu-se a clas. sificação das seis variedades quanto à curva de maturação , com a CB40-13, IAC52/150 e NA56-79 em níveis semelhantes a IAC48/65 com uma posição intermediária, a CB47-355 como de baixos teores de sacarose até agosto principalmente, e a CB41-76 com valores de ATR sempre inferiores às demais.

Considerando-se curva de maturação média para os três cortes (Figura 4) observou-se que em maio a NA56-79 e CB40-13 são mais adequadäs para colheita, com ATR médio ao redor de $80 \mathrm{~kg} / \mathrm{t}$ de cana; em junho estas variedades apresen tam uma média de ATR próximo de $90 \mathrm{~kg} / \mathrm{t}$ de cana, podendo in cluir-se a IAC52/150. A variedade IAC48/65 mostrou um ATR mé dio razoável somente após agosto e a CB47-355 em setembro, sen do a CB41-76 sem classificação para colhejta devido aos bai xos resultados de ATR rias socas.

\section{b . Área sem fertirrigação}

As curvas de maturação das seis variedades na área sem fertirrigação tambēm estão nas Figurás 1 à 4. De um modo geral o comportamento observado foi semelhante ao da área fertirrigada, porém com valores de ATR sempre superiores. A CB41-76 mostrou uma leve superioridade sobre a CB47-355, de um modo geral nos três cortes.

As curvas de maturação da cana-planta ( Figura 1) mostraram-se mais achatadas do que na primeira soca ( Figu ra 2), o que também ocorreu para a área fertirrigada. No ter ceiro corte (Figura 3) todas as variedades estudadas mostra ram nos dois ensaios curvas com a concavidade invertida, po dendo ser explicada como resultado da geada ocorrida em julho de 1981. As variedades mostraram dessecamento foliar em graus variados, porém sem efeitos aparentes na gema apical. 


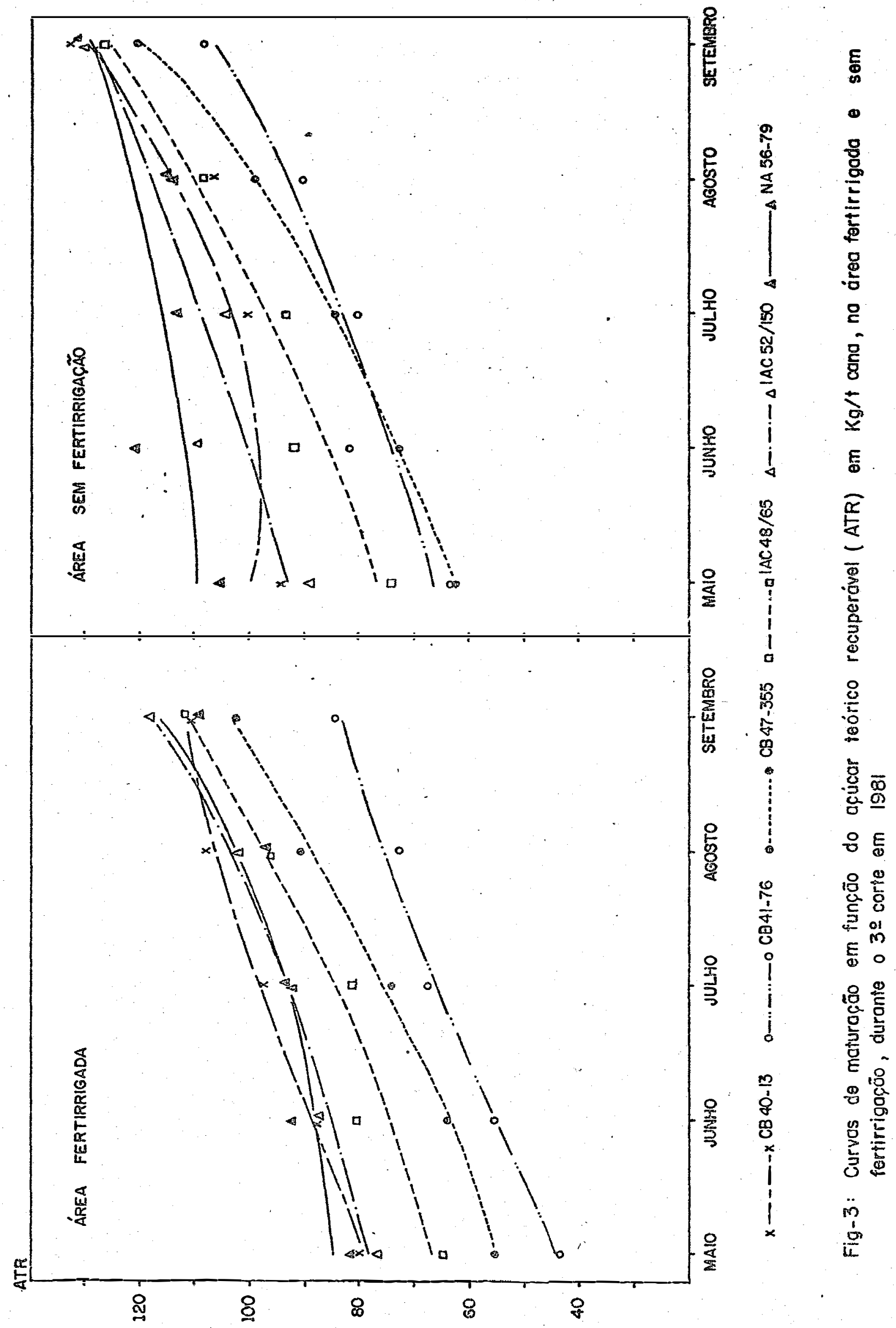




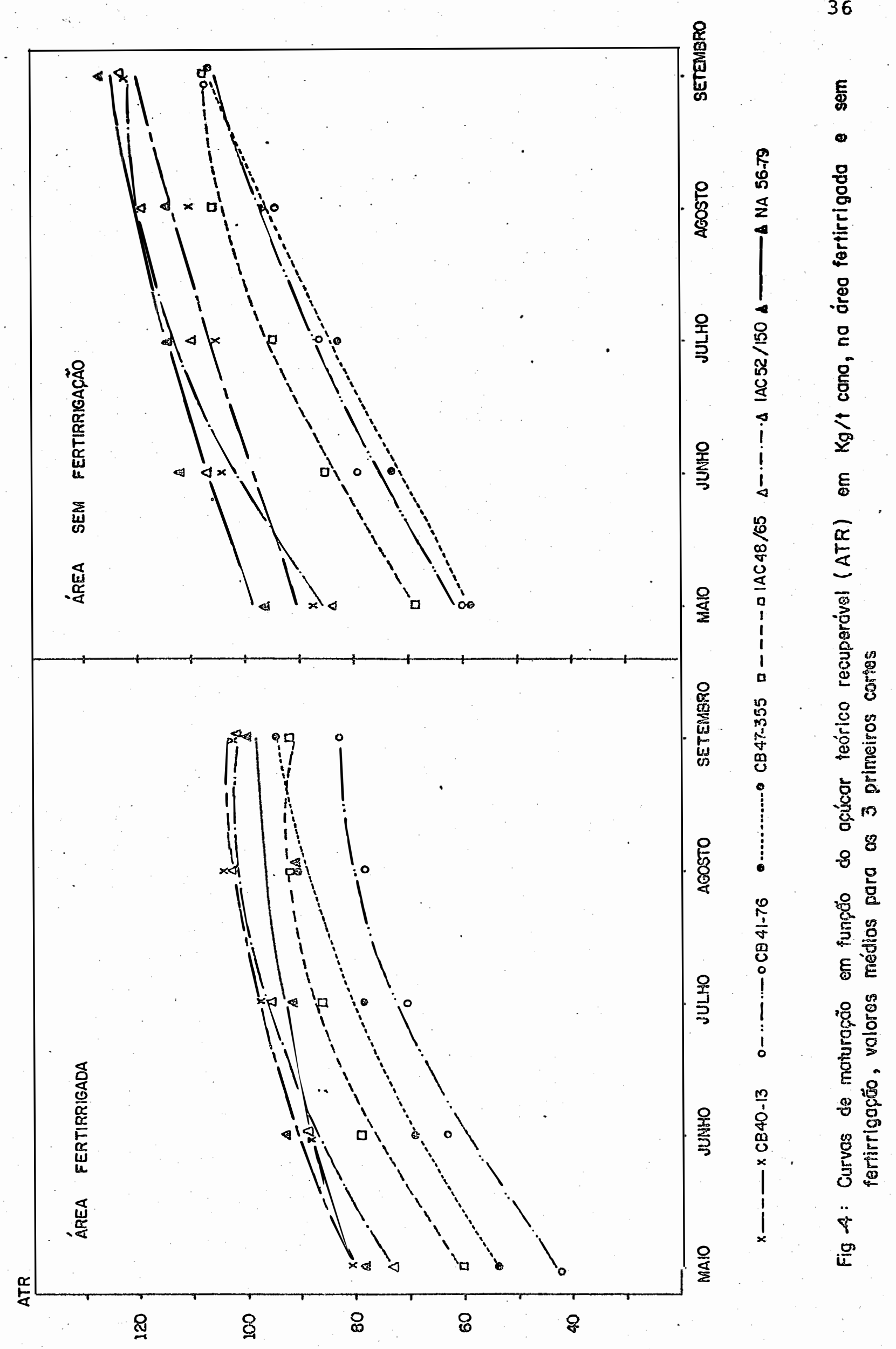


A NA56-79 apresentou em maio valores de ATR sempre superiores às demais variedades. As variedades IAC48/ 165 e. IAC52/150 resultaram curvas de maturação crescente até agosto declinando a seguir devido talvez ao florescimento. Em julho e agosto a variedade IAC52/150 alcança ou ultrapassa a NA56-79 em maturação. Estes aspectos confirmam a importância das curvas de maturação no manejo de variedadés (IINGERFELT et alii, 1965).

A variedade $C B 40-13$, com altos teores de. ATR, mostrou um leve declíneo da curva de maturação seguido de um período de aumento o que provavelmente seja devido à geada de 1981 (Fig. 3). Na média geral dos três primeiros cortes (Fig. 4) a variedade NA56-79 mostrou sempre valores mais altos de ATR, sendo alcançada pela IAC52/150 em julho e agosto. CB40-13 ficou em nivel um pouco inferior, sendo a IAC48/65 uma variedade de curva de maturação média e a CB41-76 e CB47-355 as de mais baixos valores. Entretanto, em setembro estas três últimas variedades resultaram em ATR médio ao redor dé 107 $\mathrm{kg} / \mathrm{t}$ de cana, o que representa $16 \mathrm{~kg} / \mathrm{t}$ de cana a menos da mé dia das três variedades mais ricas em sacarose no mesmo mês.

\subsection{Qualidade tecnológica da matéria-prima}

A qualidade tecnológica da cana-de-açúcar como matéria-prima para fabricação do açúcar ou do álcool, não po de ser medida unicamente pelo seu teor de sacarose, o princí pal parâmetro, mas sim por uma série de características in trínsecas da própria planta relacionados com as etapas do pro cessamento industrial.

A colheita dos ensaios em setembro de 1979. 1980 e 1981, e a análise tecnológica dos colmos, resultou em diversos parâmetros de avaliação da qualidade da cana-de-açú car. O inter-relacionameto entre estes valores exigiu uma 
discussão conjunta dos dados dos três cortes, nas āreas com e sem fertirrigação. Os resultados foram analisados estatí ticamente no esquema de parcelas subdivididas, considerando os cortes como subparcelas.

a Fibra, umidade e caldo extraído porcento cana

A Tabela 7 apresenta os valores médios de fibra : cana nas três colheitas nos dois ensaíos, assim como o valor da diferença mínima significativa (dms) pelo teste de Tukey ao nível de 5\% de probabilidade. A variação mensal dos valores de fibra é apresentado em anexo na Tabe la 33 para ós três cortes nos ensaios com e sem fertirriga ção. Nas Tabelas 8 e 9 estão os dados relativos ao caldo extraído por cento de cana e umidade \% cana, respectivamen te.

Os maiores valores de fibra foram observa dos nas variedades IAC48/65 e IAC52/150, significativamente superior às demais, sendo a de menor teor a CB47-355 . na área fertirrigada e a CB40-13 na ārea sem fertirrigação. Observou-se na média geral dos ensaios um valor inferior de fibra na cana fertirrigada ao redor de $13 \%$, $0^{\circ}$ que já havia sido constatado por SILVA et alii (1976).

Uma vez que tecnologicamente o colmo é forma do por fibra e caldo absoluto, estes valores estão relacio nados, ou seja, a IAC48̈/65 e IAC52/150 apresentaram os meno res valores de caldo extraỉdo o cana. Ocorreu significativa na análise da variância (Tabela 8) entre variedades nos três cortes nos dois ensaios, sendo que en tre cortes as variedades CB40-13 e CB47-355 não apresen taram diferenças significativas nos dois ensaios, e a CB41-76 na área fertirrigada. Estas três variedades apresen taram relativamente os mais altos valores de caldo extraî do. 
Tabela 7. Resultados médıos de fibra \% cana a diferença

mini ma significativa (dms) pelo teste de Tukey ao nível de $5 \%$ de probabilidade

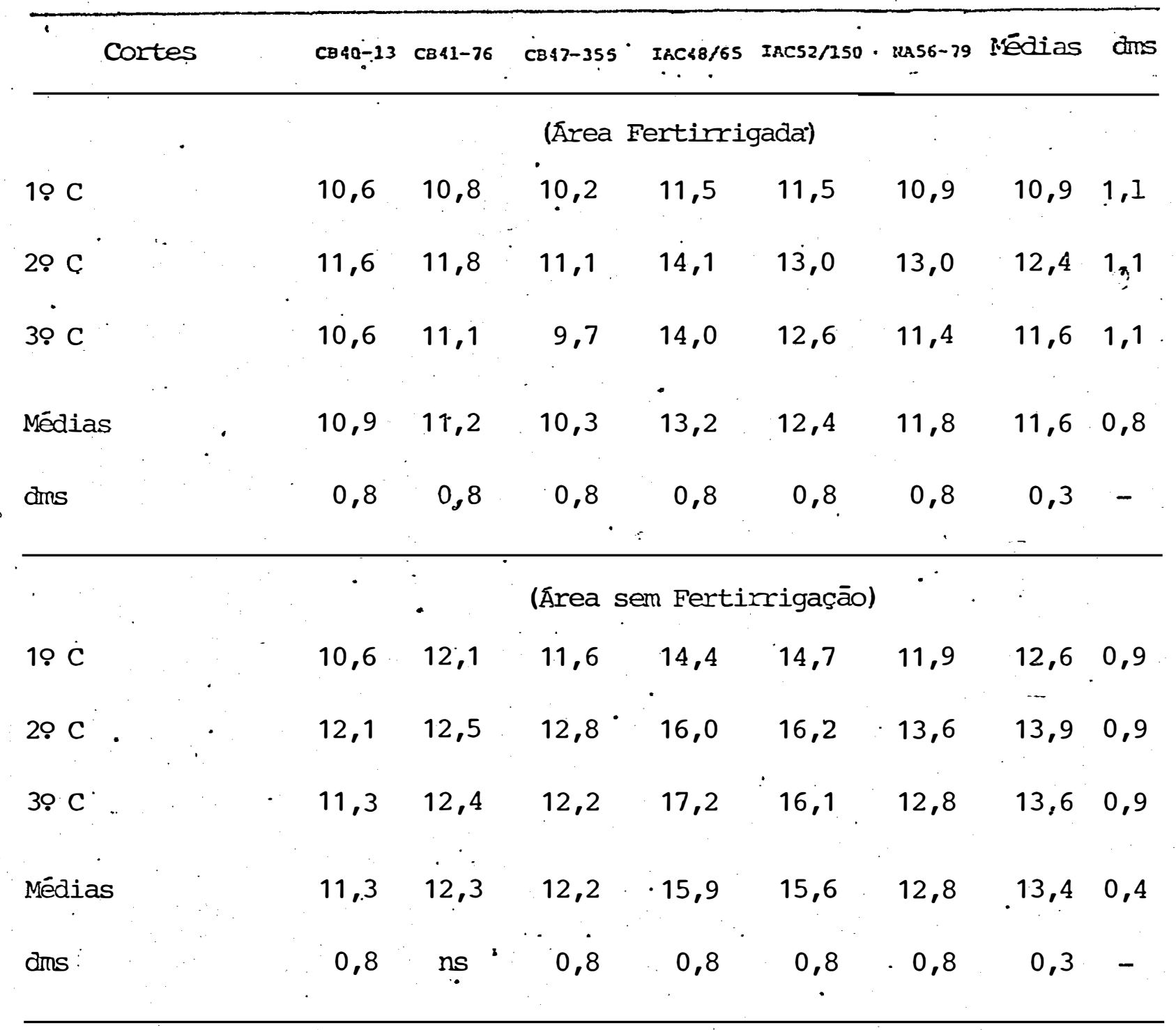

ns $=$ não significativa 
Tabela 8. Resultados médios de caldo extraído \% cana e rença mínima significativa (dms) pelo teste de Tukeȳ ao nível de 5\% de probabilidade

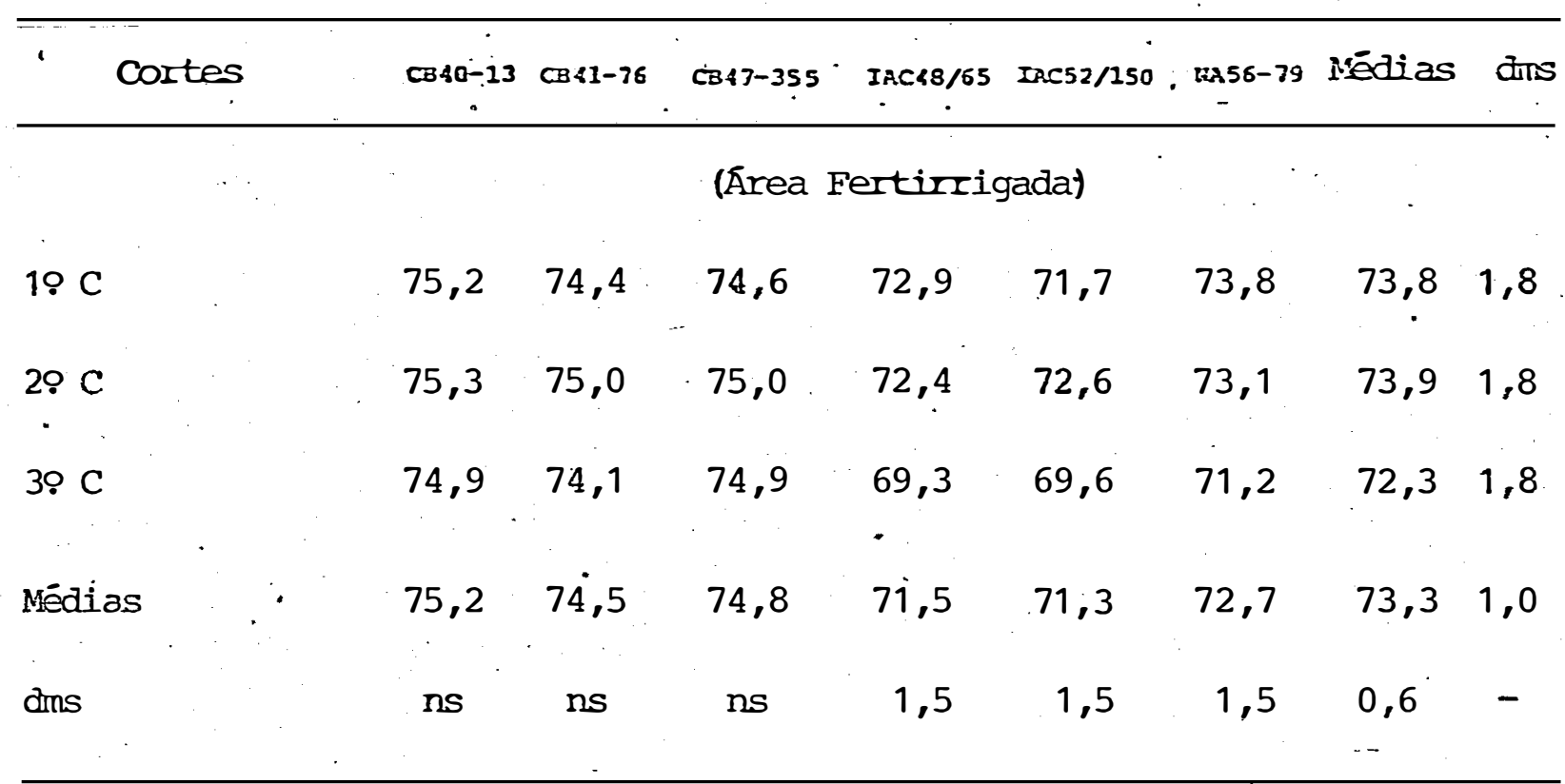

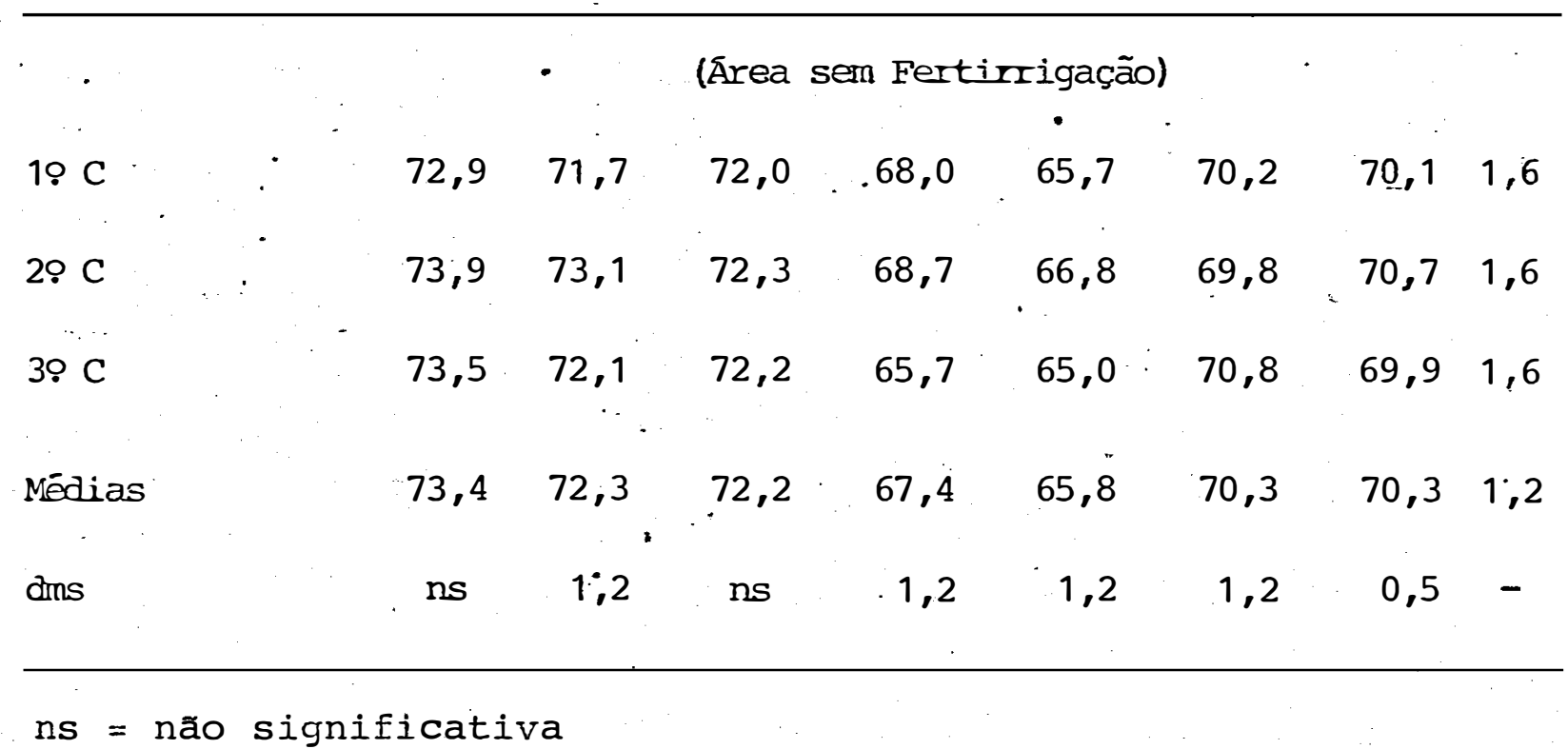


o caldo absoluto é composto de sólidos solū veis (brix) e umidade : cana, o que relaciona os valores das Tabelas 8 e 9 . No ensaio fertirrigado as variedades CB40-13, CB41-76 e CB47-355 foram as de relativo maior teor de umidade, sendo as duas primeiras, significativamente ao nivel de 5\% de probabilidade, superiores a NA56-79, IAC $48 / 65$ e IAC52/150.

No ensaio não fertirrigado a análise da variância revelou diferenças significativas entre varieda des e entre cortes. Assim como na área fertirrigada, o 39 corte foi o que apresentou o menor teor de umidade e de cal do extraído : cana. Embora tenha sido o ano que recebeu 0 maior. volume de fertirrigação (Tabela 2), foi o de meno res precipitações pluvionétricas no periodo de safra (Tabela 6 ).

b . Açúcares redutores, cinzas condutimétricas e fósfọ ro inorgânico no caldo extraído

Os açúcares redutores (glicose + frutose) es tão diretamente relacionados à máturação da cana-de-açúcar, uma vez que o teor de açúcares redutores o caldo decresce até setembro ou outubro, à medida que aumenta o valor de sa carose, como mostram os dados anexo da Tabela 23 . Assim, os açúcares redutores representam um meio eficiente para se avaliar o estágio de maturação da cana-de-açúcar.

- Na Tabela 10 estão os valores médios de acú cares redutores o caldo por ocasião das colheitas com os re sultados da análise da variância. Na área fertirrigada so mente a CB4l-76 mostrou'diferença significativa entre os três cortes, e na área sem fertirrigação a significância da análise da variância entre cortes foi para a CB47-355 e IAC48/65. Entre variedades somente na cana-planta da ärea fertirrigada não se observou diferenças siginificativas. Os valores mais altos de açúcares redutores foram apresentados pela CB47-355 e CB41-76, sendo os mais baixos na IAC52/150, em ambos os experimentos. 
Tabela 9. Resultados médios de umidade \% cana e diferença míni - ma significativa (dms) pelo teste de Tukey ao nível de 5\% de probabilidade

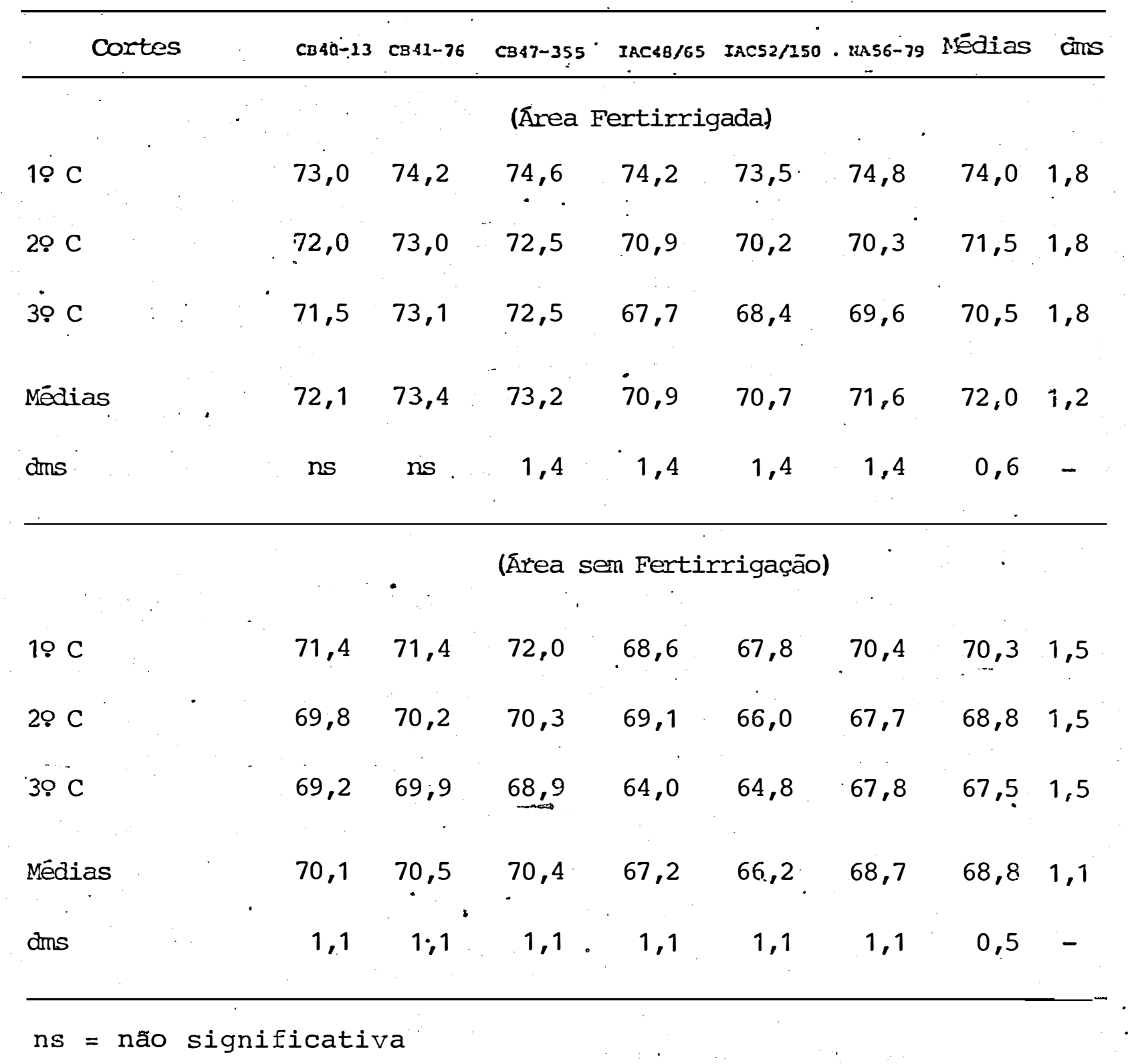


Tabela 10. Resultados médios de açúcares redutores : caldo e diferença minima significativa (dms) pelo teste de Tukey ao nível de 5\% de probabilidade

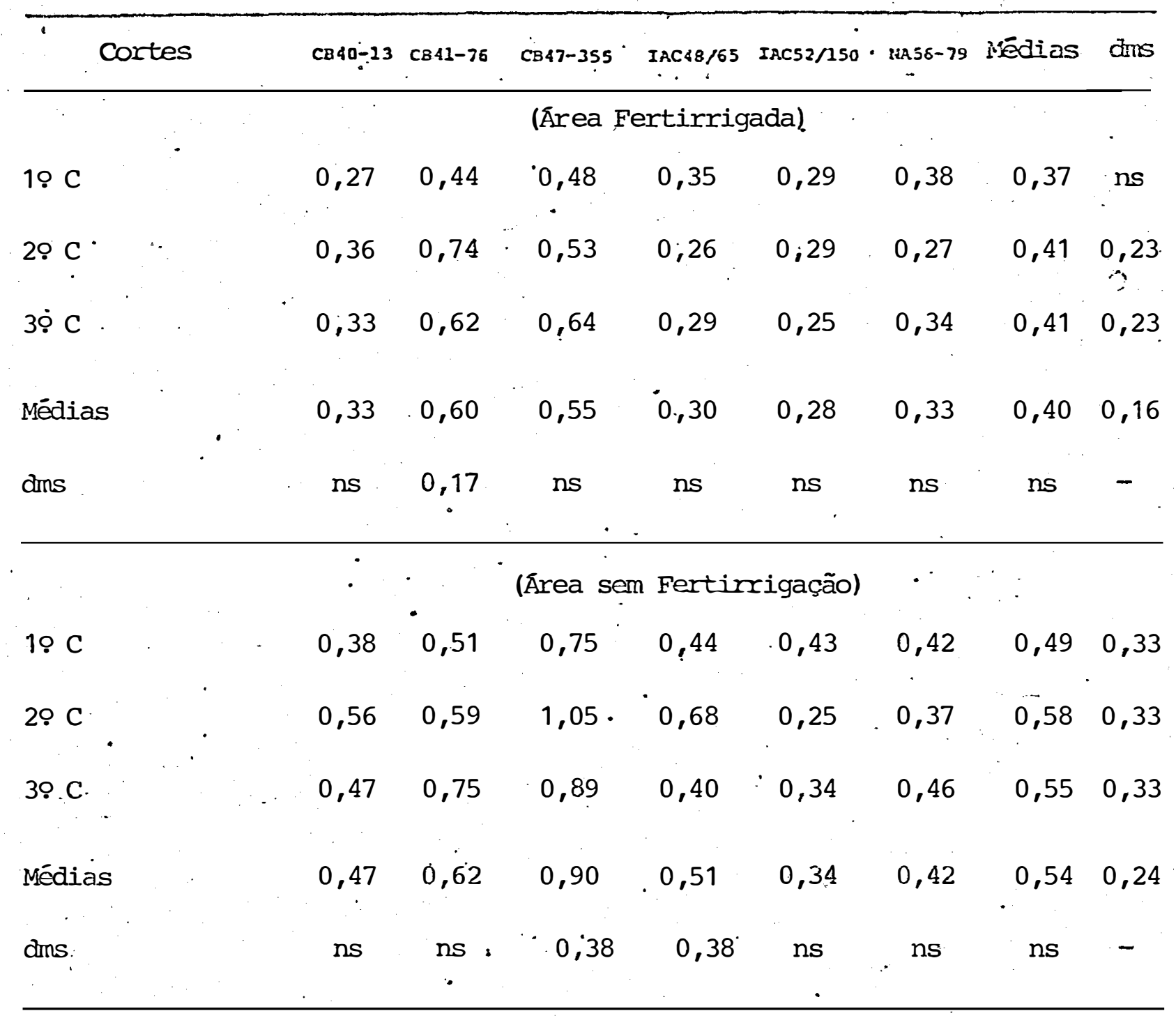

ns' = não significativa 
Confrontando-se os dois.ensaios, observou-se que a ârea fertirrigada resultou uma média geral de açúca res redutores ao redor de $26 \%$ inferior à ārea sem fertir rigação, contrariamente ao que era de se esperar, provavel mente devido a um maior consumo de glicose como energia pa ra o metabolismo e/ou efeito de diluição devido a maior umidade da cana. STUPIELLO et alii (1977) obtiveram um aumento do teor de açúcares redutores com doses crescentes de vinhaça.

A Tabela 11 apresenta os valores de cinzas condutimétricas do caldo por ocasião da colheita e as dife renças minimas significativas pelo teste de Tukey. Ambos os ensaios mostraram diferenças significativas entre varieda des nos três cortes, sendo a IAC48/65 a que apresentou os valores mais elevados. Na Tahoia 24 em anexo estão os va lores mensais do teor de cinzas nos dois ensaios.

As cinzas do caldo da cana-de-açūcar são for madas na maior parte por potássio, um elemento altamente solúvel que dificulta a cristalização da sacarose (CLARKE, 1981). Entretanto, para fermentação alcoólica os sais de potássio são catalizadores e nutrientes para as leveduras. Como a fertirrigação elevou o teor de cinzas em 159\%,. na média geral, isto poderia indicar uma matéria-prima mais adequada para produção de álcool, o que ainda necessita de comprovação experimental.

O fósforo inorgânico $\left(\mathrm{P}_{2} \mathrm{O}_{5}\right)$ do caldo da ca na-de-açúcar representa importante elemento tanto na fabri cação do açücar, por auxiliar a clarificação, como na pro dução de álcool, por ser"nutriente essencial. A Tabela 12 resume as médias obtidas nas três colheitas, com diferença significativa entre variedades, exceto no primeiro corte para os dois ensaios. Entre cortes as variedades mostraram diferença significativas, exceto a CB40-13 em área fertir rigada. A NA56-79 apresentou nos três cortes a maior média de $\mathrm{P}_{2} \mathrm{O}_{5}$, significativamente superior às demais 
Tabela 11. Resultados médĩos de cinzas condutimétricas : caldo e diferença mínima significativa pelo teste de Tukey ao nível de 5응 de probabilidade

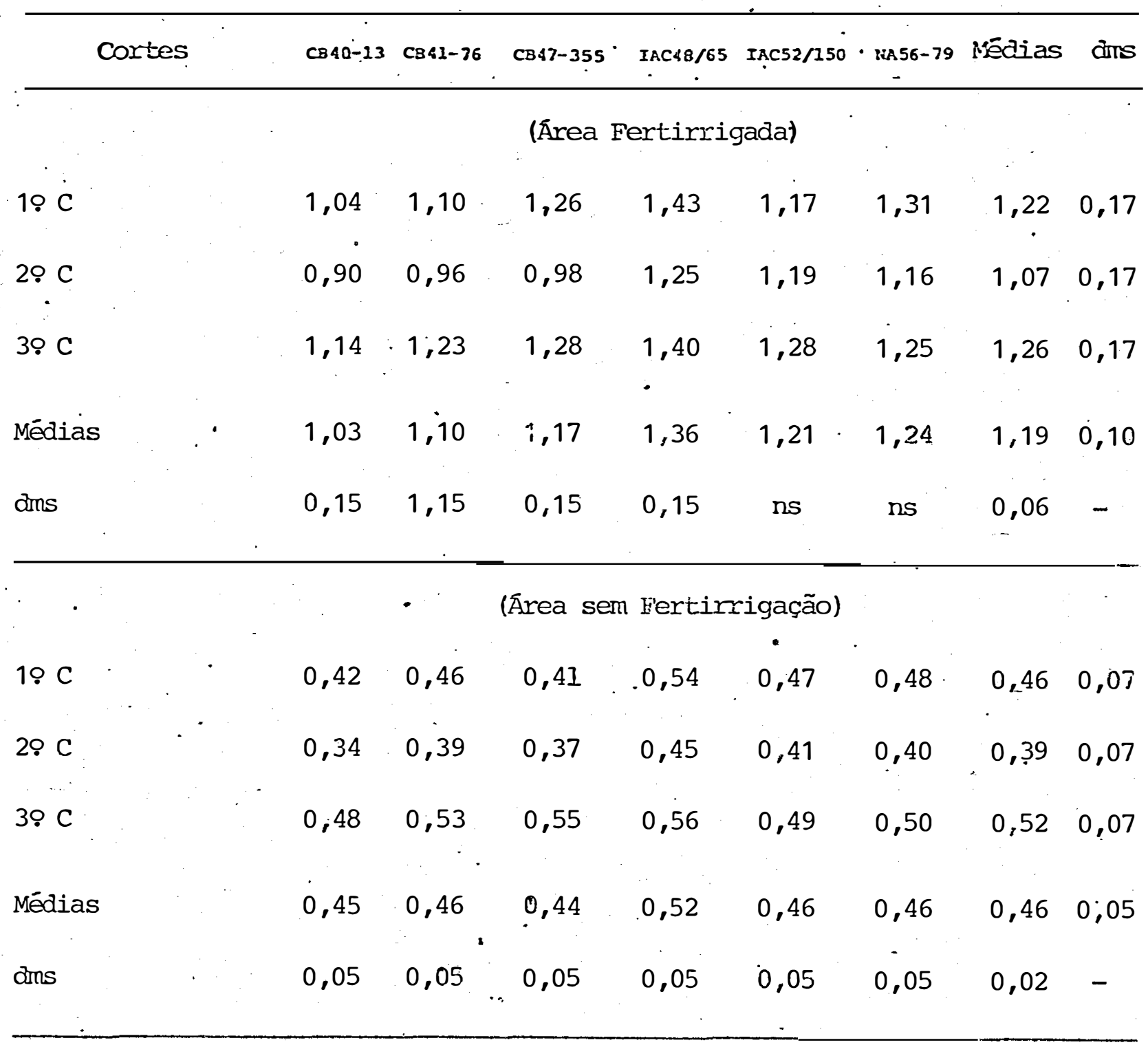

ns = não significativa 
Tabela 12. Resultados mêdios de fósforo inorgânico do caldo $\left(\mathrm{P}_{2} \mathrm{O}_{5}\right)$ em mg/litro e diferença mínima significativa (dms) pelo teste de Tukey ao nivel de 5\% de probabi lidade

\begin{tabular}{|c|c|c|c|c|c|c|c|c|}
\hline Cortes & $\operatorname{c8} 40-13$ & CB41-76 & $C B 47-35.5$ & $I A C \& 8 / 65$ & $\operatorname{IAC52/150}$ & . $22856-79$ & Médias & dins \\
\hline \multicolumn{9}{|c|}{ (Área Fertirrigada) } \\
\hline $19 \mathrm{C}$ & 143 & 168 & $\begin{array}{c}142 \\
.\end{array}$ & 149 & 175 & 144 & 154 & ns \\
\hline $29 \mathrm{C}$ & 245 & 250 & 196 & 219 & 209 & 309 & 231 & .97 \\
\hline $30^{\circ} \mathrm{C}$ & 210 & 284 & 278 & 230 & 297 & 419 & 286 & 97 \\
\hline Médias & 199 & 23.4 & 205 & 199 & 227 & 291 & 223 & 01 \\
\hline dms & ns & 80 & 80 & 80 & 80 & 80 & 33 & - \\
\hline \multicolumn{7}{|c|}{ (Ārea sem Fertirrigação) } & - & \\
\hline $19 \mathrm{C}$ & 178 & $\cdot 220$ & 233 & 174 & 264 & 253 & 220 & ns \\
\hline $29 \mathrm{C}$ & 305 & 376 & 374 & 384 & 407 & 453 & 383 & 103 \\
\hline $39 \mathrm{C}$ & 302 & 406 & 388 & 406 & $3 \dot{3} 7$ & 391 & 372 & 103 \\
\hline . … & & & & & & & & \\
\hline Médias & 261 & 334 & 332 & 321 & 336 & 366 & $325^{\circ}$ & 73 \\
\hline dms & 79 & 79 & 79 & 79 & 79 & 79 & 32 & - \\
\hline
\end{tabular}

ns = não significativa 
variedades no ensaió com fertirrigação: A variação mensal de $\mathrm{P}_{2} \mathrm{O}_{5}$. durante a safra está ná Tabela 25 anexa.

c. Brix, pol e pureza de cana-de-açúcar

Os resultados médios de brix : cana, são apresentados na Tabela 13, assim como os valores da dife rença minima significativa pelo teste de Tukey, obtidos por ocasião das colheitas nos dois ensaios.

Na Tabela 14 estão os valores de poljo cana e na Tabela 15 o.s resultados de pureza obtidos no mês de setembro, na colheita dos ensaios. Naturalmente, brix, pol e pureza estão relacionados, assim como a discussão dos re sultados. Anexo, nas Tabela 26,27 e 28 são apresentados os dados mensais destes parâmetros.

A pol : cana representa o principal parâme tro de qualidade da cana-de-açúcar por ser o açúcar crista lizável e por representar a maior proporção dos açúcares. fermentes civeis em cana madura: As variedades estudadas diferem significa tivamente, com a CB40-13, IAC52/150 e NA56-79 apresentando as maiores médias de pol, brix e pureza em ambos os en saios, confirmamdo as curvas de maturação. A pureza. foi significativamente diferente entre variedades e, em alguns casos, entre safras. A CB41-76 apresentou a menor pureza na årea fertirrigada e a CB47-355 na área sem fertirrigaçãc.

d. Açúcares totais por cento de cana

Os açúcarès totais representam a soma da sacarose convertida em açúcares invertidos e dos açúcares redutores. A Tabela 16 mostra os dados obtidos e a análise da variância (dms). Uma vez que a pol o cana, que é apro ximadamente a sacarose, representa a maior parte dos açū cares totais, os resultados obtidos para estes parâmetros 
Tabela 13. Resultados méáios de Brix \% cana e diferença míni ma significativa (ams) pelo teste de Tekey ao nive $\overline{\dot{I}}$ de $5 \%$ de probábilidade

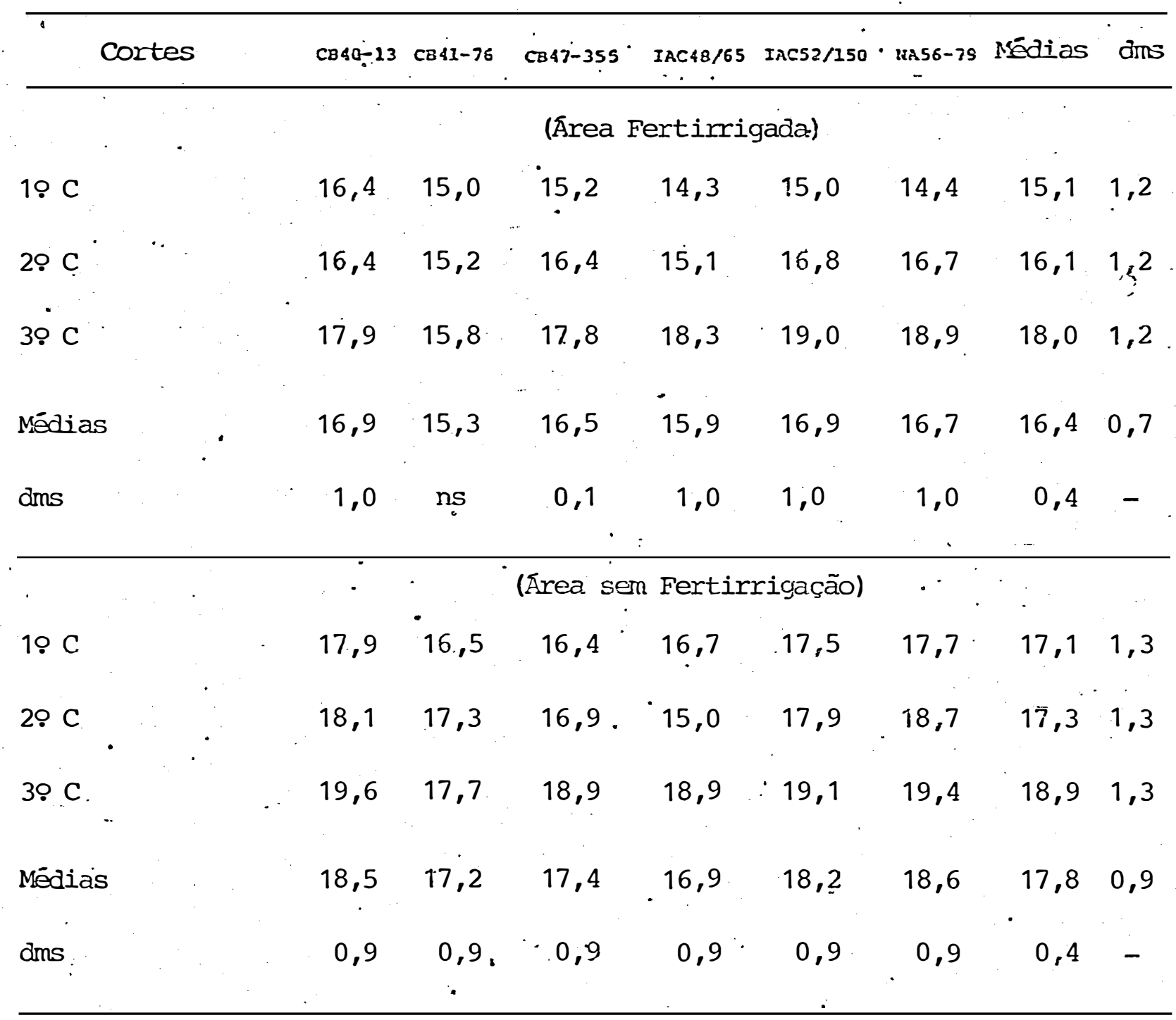

ns'= não significativa 
Tabela 14. Resultados médios de pol \% cana e diferença mínima significativa (dms) pelo teste de Tukey ao nivel de $5 \%$ de probabilidade

\begin{tabular}{|c|c|c|c|c|c|c|c|c|}
\hline Cortes & $\mathrm{CB} 80-13$ & CBA1-76 & $C B 47-355^{\circ}$ & IAC $48 / 65$ & $\operatorname{IAC5} 2 / 150$ & - $3455-79$ & rédias & àrs \\
\hline & \multicolumn{8}{|c|}{ (Ârea Fertirrigada). } \\
\hline $19 \mathrm{C}$ & 13,5 & 11,9 & 12,0 & 11,3 & 12,2 & 11,5 & 12,1 & 1,3 \\
\hline $29 \mathrm{C}$ & 13,0 & 11,6 & 13,0 & 12,0 & 13,4 & 13,5 & $12 ; 7$ & 1,3 \\
\hline $3 \stackrel{\circ}{C}$ & 14,6 & 12,1 & 14,0 & 14,9 & 15,5 & 15,5 & 14,4 & 1,3 \\
\hline Médias & 13,7 & 11,9 & 13,0 & 12,7 & 13,7 & 13,5 & 13,1 & 0,7 \\
\hline \multirow[t]{2}{*}{ dins } & 1,1 & ns & 1,1 & 1,1 & 1,1 & 1,1 & 0,4 & - \\
\hline & \multicolumn{7}{|c|}{ (Ârea sem Fertirrigaŗão) } & \\
\hline $19 \mathrm{C}$ & 15,4 & 13,9 & 13,6 & 14,1 & 14,8 & 15,1 & 14,5 & 1,6 \\
\hline $29 \mathrm{C}$ & 14,8 & 14,2 & 13,2 & 12,1 & 15,6 & 16,3 & 14,4 & 1,6 \\
\hline $39 \mathrm{C}$ & 16,6 & 14,4 & 15,6 & 16,2 & $\cdot 16,5$ & 16,6 & $=16,1$ & 1,6 \\
\hline Médias & 15,6 & $14 ; 1$ & 14,2 & 14,4 & 15,6 & 16,0 & 15,0 & 1,1 \\
\hline dins & 1,3 & $\begin{array}{c}\text { ns } \\
\text {. }\end{array}$ & 1,3 & 1,3 & 1,3 & 1,3 & 0,5 & - \\
\hline
\end{tabular}

$\mathrm{ns}=$ não significativa 
TaBela 15. Resultados médios de pureza da cana e diferença minima significativa (dms) pelo teste de Tukey ao nível de $5 \%$ de probabilidade

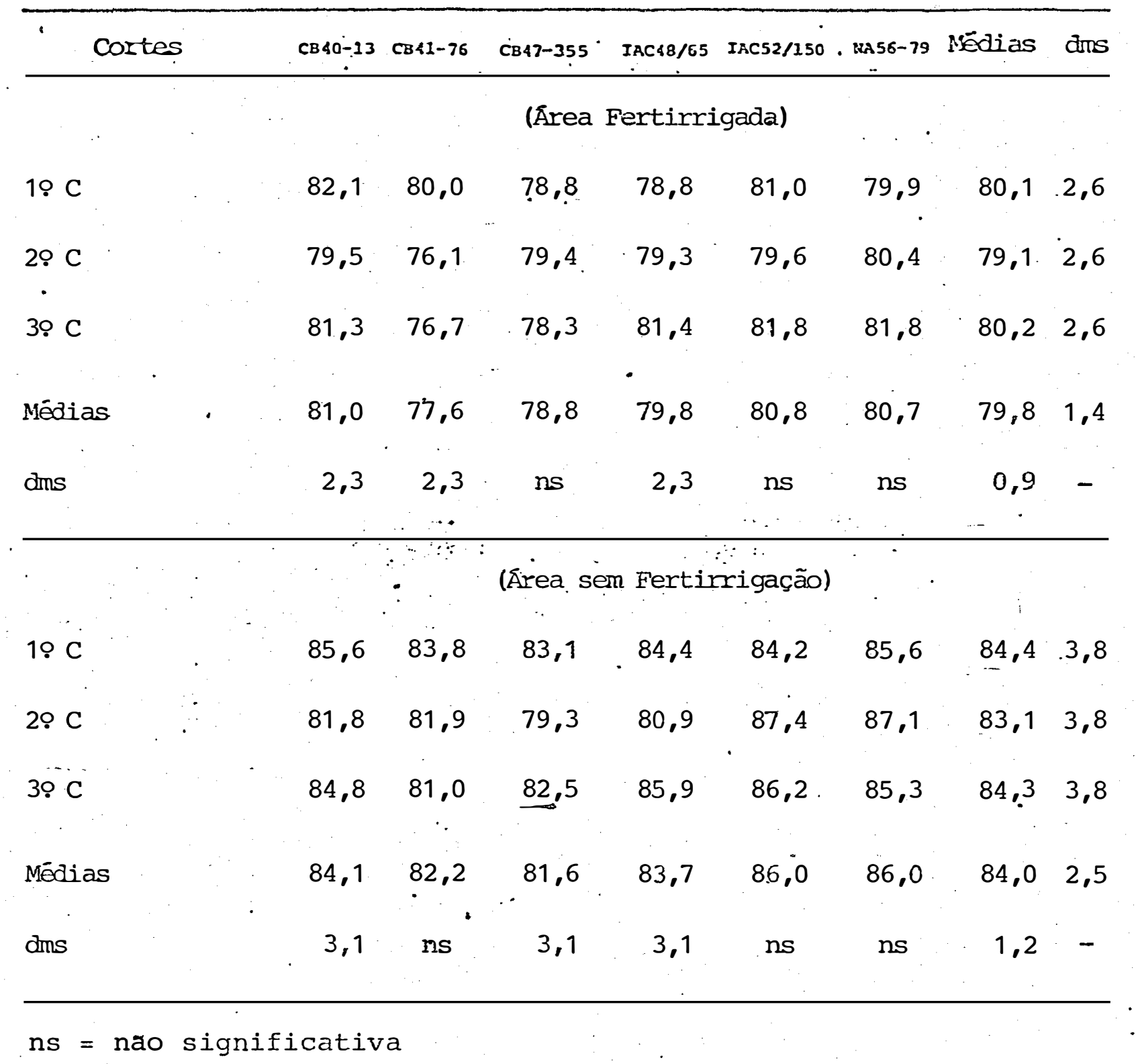


Tabela 16. Resultados médios de açúcares totais o cana e difẹ rença minima significativa (dms) pelo teste de Tukey ao nivel de 5\% de probabilidade

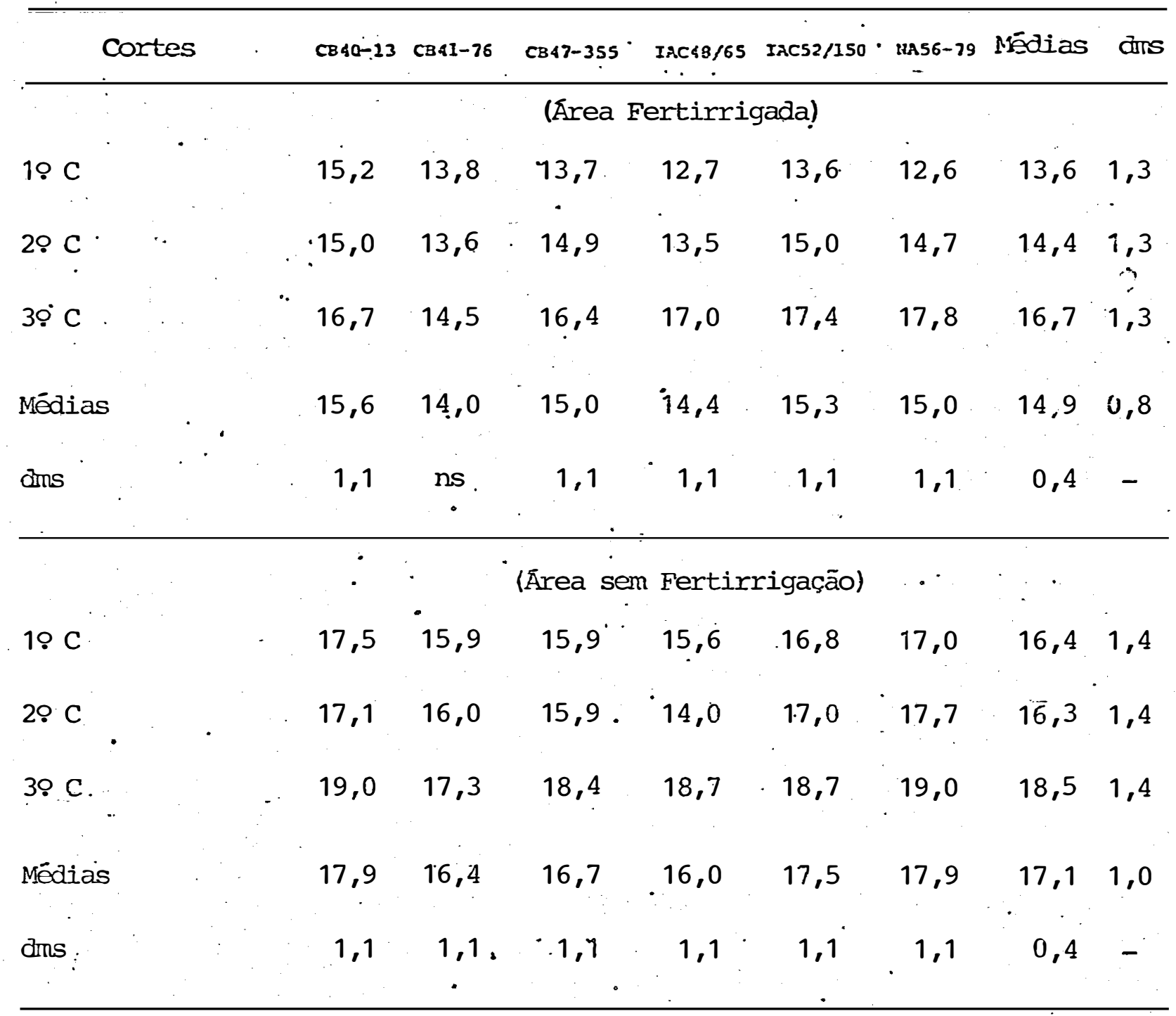

ns '= não significativa 
são bastante semelhantes.

Assim, as variedades CB40-13, NA56-79. e

IAC52/150 resultaram as médias mais elevadas nos três cor tes sem fertirrigação. No ensaio fertirrigado a NA56-79 apresentou uma média de açúcares totais do mesmo nível da CB47-355, devido ao baixo valor obtido no primeiro corte, quando apresentou uma curva de maturação irregular. Anexo, na Tabela 29 estão os valores médios mensais de açúcares totais \% cana nos dois ensaios durante os três cortes.

\subsection{Produtividades nas colheitas}

a . Rendimentos teóricos de açúcar . e álcool

Através dos valores de añálise tecnológica, foi possivel o cálculo do açúcar teórico recuperável (ATR) e do álcool provável direto (EPD), de acordo com COPERSUCAR (1978) e COPERSUCAR (1979). Estas equações levam em conside ração os valores de pol \% cana, fibra : cana e pureza da ca na para ATR, e de açúcares totais e fibra o cana para EPD. Por não considerarem os demais fatores da matéria-prima in terferentes nos rendimentos do açúcar e álcool, como teor de cinzas ou sais solúveis fósforo, tipo de fibra, e outros, estas equações apresentam certa limitação.

As Tabelas 17 e 18 apresentam os rendimentos teóricos de açúcar (ATR) e de álcool (EPD). em quilos e lí tros por tonelada de cana, respectivamente. A análise da variância mostrou que as variedades diferem significativa mente entre $\dot{s}$, assim como entre safras ou corte, exceto a CB41-76 para os dados de ATR.

Na área fertirrigada a variedade CB40-13 apre sentou os valores mais elevados de ATR e EPD, porém sem di ferença significativa com a NA56-79 e IAC52/150 para ATR e com estas mesmas variedades e a CB 47-355 para EPD, considerando-se a média de três cortes no mês de 
Tabela 17. Resultados médios de açúcar teórico recuperável(ATR) em $\mathrm{kg} / \mathrm{t}$ de cana e diferença mínima significativa (dms) pelo teste de Tukey ao nível de 5\% de probabi lidade

\section{Cortes}

CB40-13 CB41-76

c347-355

IAC 8 8/65

IAC52/150

uass-z9 Nédias âns

\section{(Ārea Fertinrigaāa)}

10 C

$102,7.86,6 \quad 86,3 \quad 79,6 \quad 89,8$

$82,8 \quad 88,8 \quad 12,8$

2. $\mathrm{C}$

$\begin{array}{llllllll}95,0 & 78,8 & 95,2 & 84,4 & 97,0 & 98,9 & 91,6 & 12,8\end{array}$

$30 \mathrm{C}$

$\begin{array}{llllllll}110,8 & 84,6 & 102,2 & 111,5 & 118,0 & 118,0 & 107,6 & 12,8\end{array}$

Médiás

102,8

$83,3 \quad 94,6$

91,8

101,6

100,2

$95,7 \quad 6,5$

dms

$$
11,5
$$

ns

11,5

11,5

11,5

11,5

(Área sem Fertinrigação)

$10 \mathrm{C}$

$\begin{array}{llllllll}123,0 & 107,0 & 104,5^{\circ} & 108,3 & 113,6 & .120,0 & 112,7 & 17,2\end{array}$

2. C

$\begin{array}{llllllll}112,6 & 108,1 & 96,8 & 86,1 & 123,8 & 131,2 & 10 \overline{9}, 6 & 17,2\end{array}$

3̧. C.

$132,6 \quad 107,3$

119,9

126,6

130,1

131,8

$124,7 \quad 17,2$

Médias

$$
122,7
$$

107,0

107,0

122,5

127,7

$115,7 \cdot 12,4$

dins 
Tabèla 18. Resultados médìos de álcool provável direto (EPD) em litros de álcool/t cana e diferença mínima signifi. cativa (dms) pelo teste de Tukey ao nível de 5\% de probabilidade

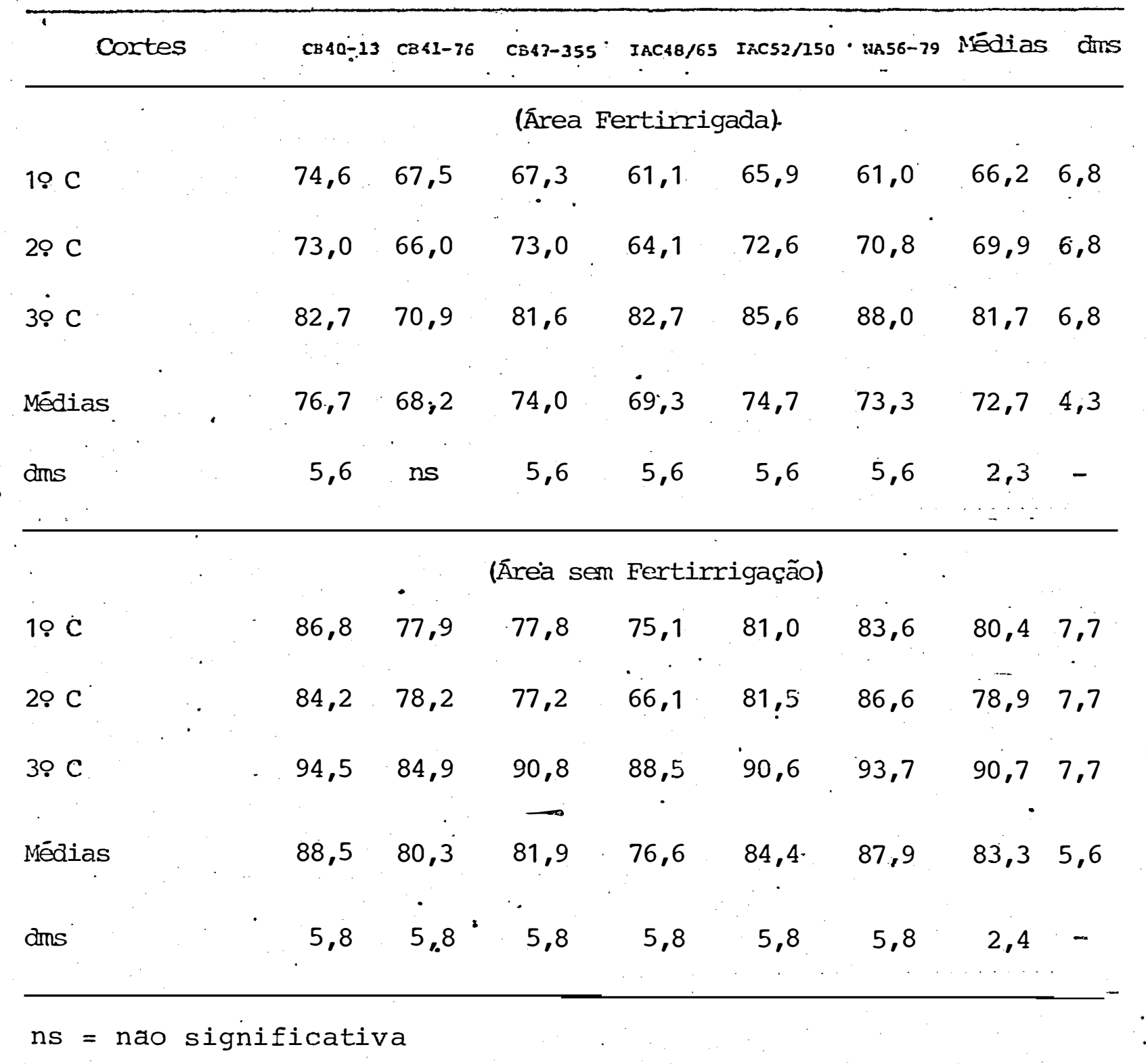


setembro.

A classificação relativa das variedades (Tâ bela 17), em função do ATR médio dos três primeiros cortes, foi a seguinte:

Área Fertirrigada

Variedades ATR Tukey
Ārea sem Fertirrigação

Classif. Variedades ATR Tukey Classif.

$\begin{array}{lrlcllll}\text { CB40-13 } & 102,8 & \text { a } & \text { alta } & \text { NA56-79 } & 127,7 & \text { a } & \text { alta } \\ \text { IAC52/150 } & 101,6 & \text { a } & \text { alta } & \text { CB40-13 } & 122,7 & \text { a } & \text { alta } \\ \text { NA56-79 } & 100,2 & \text { a b } & \text { alta/média } & \text { IAC52/150 } & 122,5 & \text { a } & \text { alta } \\ \text { CB47-355 } & 94,6 & \text { b c } & \text { média } & \text { CB41-76 } & 107,1 & \text { b } & \text { média } \\ \text { IAC48/65 } & 91,8 & \text { c } & \text { média } & \text { CB47-355 } & 107,0 & \text { b } & \text { média } \\ \text { CB41-76 } & 83,3 & . & \text { d baixa } & \text { IAC48/65 } & 107,0 & \text { b } & \text { média }\end{array}$

Adotando os mesmos critérios para o rendimen to teórico de álcool (EPD) pode-se obter a seguinte clas sificação para a méłia dos três cortes:

Ārea Fertirrigada

Variedades EPD Tukey Classif. Variedades EPD Tukey Classif.

\begin{tabular}{|c|c|c|c|c|c|c|c|}
\hline CB40-13. & 76,7 & $a$ & alta & CB40-13 & 88,5 & $a$ & alta \\
\hline IAC52/150 & 74,7 & $a b$ & alta & NA56--79 & 87,9 & $\mathrm{a}$ & alta \\
\hline CB47-355 & 74,0 & $a b$ & alta & IAC52/150 & 84,4 & $a b$ & alta/méäia \\
\hline NA56-79 & 73,3 & $\mathrm{~b} c$ & alta/média & CB47-355 & 81,9 & $\mathrm{~b} \mathrm{c}$ & Inédia \\
\hline IAC48/65 & 69,3 & c d & média/baixa & CB41-76 & 80,3 & $\mathrm{~b} c$ & média/baixa \\
\hline CB41-76 & 68,2 & d & baixa & IAC48/65 & 76,6 & C & baixa \\
\hline
\end{tabular}

Esta classificação relativa no teste de Tü key ao nível de 5\% de probabilidade, permite constatar que na ārea fertirrigada as variedades CB40-13 e IAC52/150 mostram altos rendimentos de ATR ou EPD. A NA56-79 apresen tou-se em nível entre alto e médio, assim como a CB47-355, enquanto que a IAC48/65 esteve em nível médio e a CB41-76 
foi classificada coma o de baixo rendimento.

Por outro lado, no experimento sem

ferti rigação as variedades alteraram a classificação,

ficando a NA56-79, CB40-13 e IAC52/150 como de altos rendimentos de ATR e EPD. As variedades CB41-76, CB47-355 e IAC48/65 ficaram com classificação média, mas a última pode ser con siderada relativamente de baixo rendimento de álcool pro vável.

Considerando-se a média geral das seis vâ riedades em cada corte, os maiores valores de ATR e EPD ocorreram no terceiro corte, tanțo na área fertirrigada co mo na área sẹ fertirrigação. As condições climāticas : fo ram mais favoráveis à maturação durante o terceiro corte, quando no período de abril a setembro a precipitação plu viométrica total foi de $193 \mathrm{~mm}$ e a diferença entre as tem peraturas máxima e mínima média de período foi de 15,79c. Nos anos anteriores, 1979 e 1980, o total de chuvas no mes mo periodo foram de 467 e $422 \mathrm{~mm}$, respectivamente, e a diferença entre as temperaturas foi de 14,70. para os '.' dois anos.

O maior volume de restijo aplicado no ter ceiro corte (Tabela 2) não provocou alterações diferentes daquelas observadas nos cortes anteriores. Provavelmente, isto seja devido ao fato de o solo da área fertirrigada estar recebendo restilo durante vários anos, ' provocando uma elevação dos teores de nutrientes no solo até níveis de saturação. As alterações químicas no solo resultante da aplicação de altos volumes de restilo devem ainda ser me lhor pesquisadas.

Considerando-se a média geral de cada en saio, observou-se que a fertirrigação provocọu uma redução maior no ATR $(-17,3 \%)$ do que no rendimento de EPD $(-12,7 \%)$, embora não seja possível uma comparação estatística dos re sultados, devido ao delineamento dos ensaiọs. 
b . Produtividade de dolmos

Com a produção de colmos de cada parcela foi calculada a produtividade em toneladas de colmos por hectare. A média de cada variedade em cada corte e para os três cortes nos ensaios com e sem fertirrigação, assim como os valores da differença mínima significativa (dms), são apresentados na Tabela 19.

Utlizandó-se a média geral dos três prí meiros cortes, as variedades podem ser classificadas na se guinte escala na área fertirrigada:

\begin{tabular}{|c|c|c|c|c|}
\hline Variedades & $(t / h a)$ & Tukey & $(5 \%)$ & Classificação \\
\hline NA56-79 & 138 & $a$ & & alta \\
\hline IAC $48 / 65$ & 133 & $\mathrm{a}$ & & alta/média \\
\hline CB 47-355 & 128 & $\mathrm{~b}$ & c & média \\
\hline IAC52/150 & 126 & $\mathrm{~b}$ & c & méaia \\
\hline CB $41-76$ & 124 & & c & média/oaixa \\
\hline CB $40-13$ & 115 & & $\mathrm{~d}$ & baixa \\
\hline
\end{tabular}

$\mathrm{Na}$ ārea sem fertirrigação à classificação da produtividade de colmos média dos três.primeiros "cortes foi :

\begin{tabular}{|c|c|c|c|}
\hline Variedades & $(t / h a)$ & Tukey $(5 \%)^{-}$ & Classificação \\
\hline NA56-79 & 102 & $a$ & alta \\
\hline IAC $48 / 65$ & 102 & a & alta \\
\hline CB $41-76$ & 102 & $\mathrm{a}$ & alta \\
\hline CB $47-355$ & 97 & $\mathrm{a}$ & média \\
\hline CB $40-13$ & 94 & $\mathrm{~b}$ & baixa \\
\hline IAC $52 / 150$ & 91 & $\mathrm{~b}$ & baixa \\
\hline
\end{tabular}


- Tabela 19. Resultados médios de produtividade de colmos (t/ha) e diferença mínima significativa (dms) pelo teste de Tukey ao nível de 5\% de probabilidade

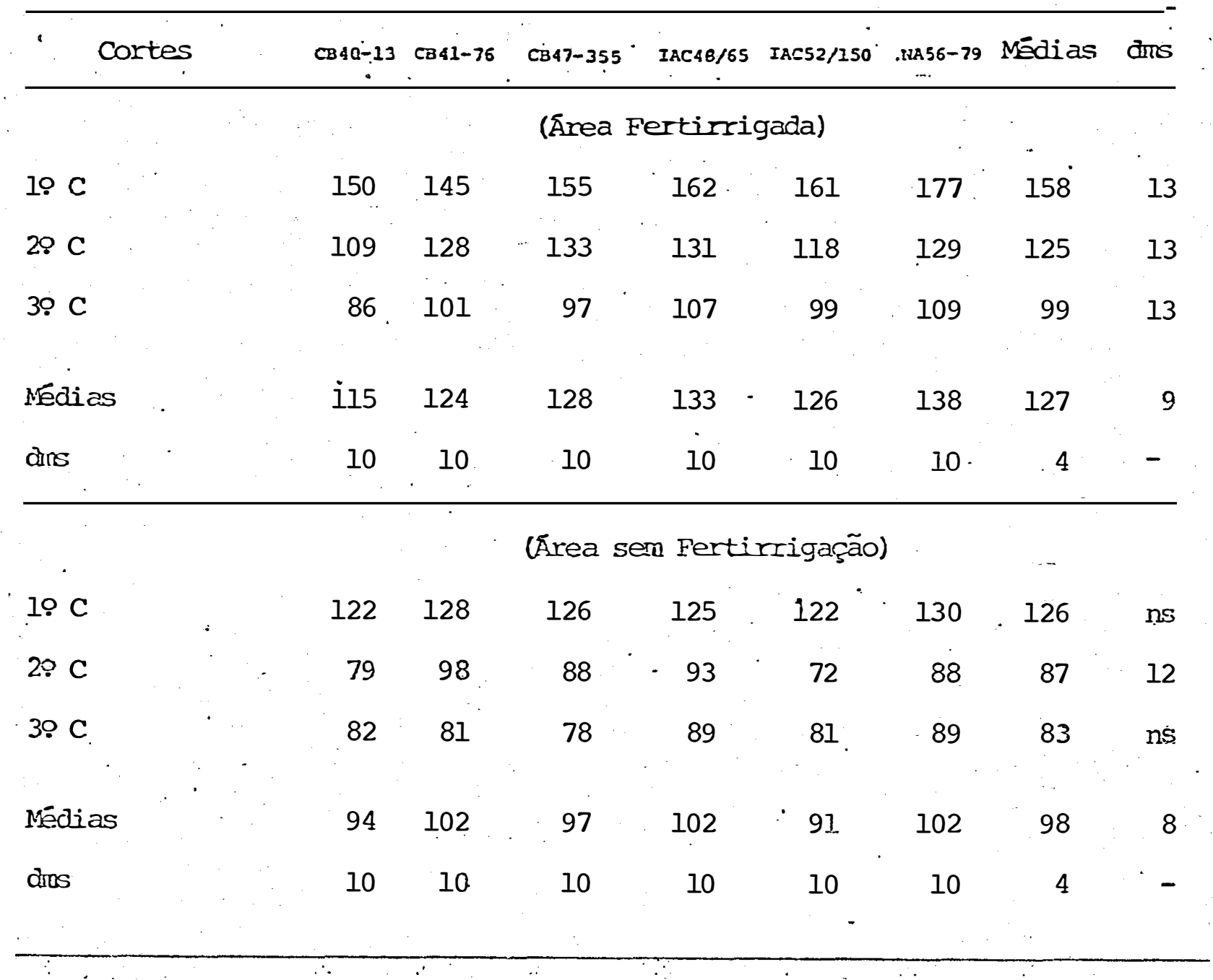

$\mathrm{ns}=$ não significativa 
Consi-derando a média geral dos três cortes, ocorreu uma significativa redução de produtividade em bos ensaios. Na área fertirrigada, o terceiro corte duziu $37,3 \%$ menos colmos do que no primeiro corte, pro응 que na área sem fertirrigação a redução foi de $34,1 \%$ entre estes cortes.

$$
\text { AGUJARO (1979) obteve na safra 75/76 }
$$

na Usina Tamoio - Araraquara - SP, uma redução de 11,0\% entre - 19 e 049 corte, através da fertirrigação com vinhaça, en - quanto que na área sem vinhaça a redução foi de $44,8 \%$.

$$
\text { Na Usina da Pedra em Serrana - SP, }
$$

os dados obtidos por GLÓRIA e MAGRO (1977) mostraram uma redução entre o $1 \%$ e $4 \%$ corte para produtividade de colmos (t/ha) de $70,8 \%$ e $69,1 \%$, para a área sem fertirrigação e fertirrigada, respectivamente.

ROSSETTO at alii (1978) no mesmo setor da Usina São João - Araras - SP da condução deste 'trabalho, observaram que a área fertirrigada apresentou pequenas reduções de produtividade entre a cana-planta e as so queiras. Os valores obtidos por estes autores foram infe riores aos observados neste trabalho, embora do mesmo nivel do 2\% ao 5\% corte. LORENZETTI e FREITAS (1978) e AGUJARO (1979) afirmaram também que a fertirrigação mantém os valo res de produtividade ( $t / h a)$ no mesmo nivel, enquanto que nas áreas sem restilo a redução na cana-soca é mais acen tuada. A Tabela 30 mostra que ambos os ensaios (com e sem fertirrigação) apresentaram redução nas soqueiras, provavel mente por estarem instalados em solo de fertilidade e condi ções físicas (Latossol Vermelho Escuro - orto) não limi tantes para a cultura. Isto também pode explicar o fato de não ter-se observado diferenças significativas entre va riedades no 19 e 39 corties, na área sem fertirrigação.

c . Rendimentos teóricos por hectare

Atravës dos valores de toneladas de cana por 
Tabela 20. Resultados médios de produtividade de açūcar ( $t / h a)$ e diferença minima significativa (dms) pelo teste de Tukey ao nivel de 5\% de probabilidade

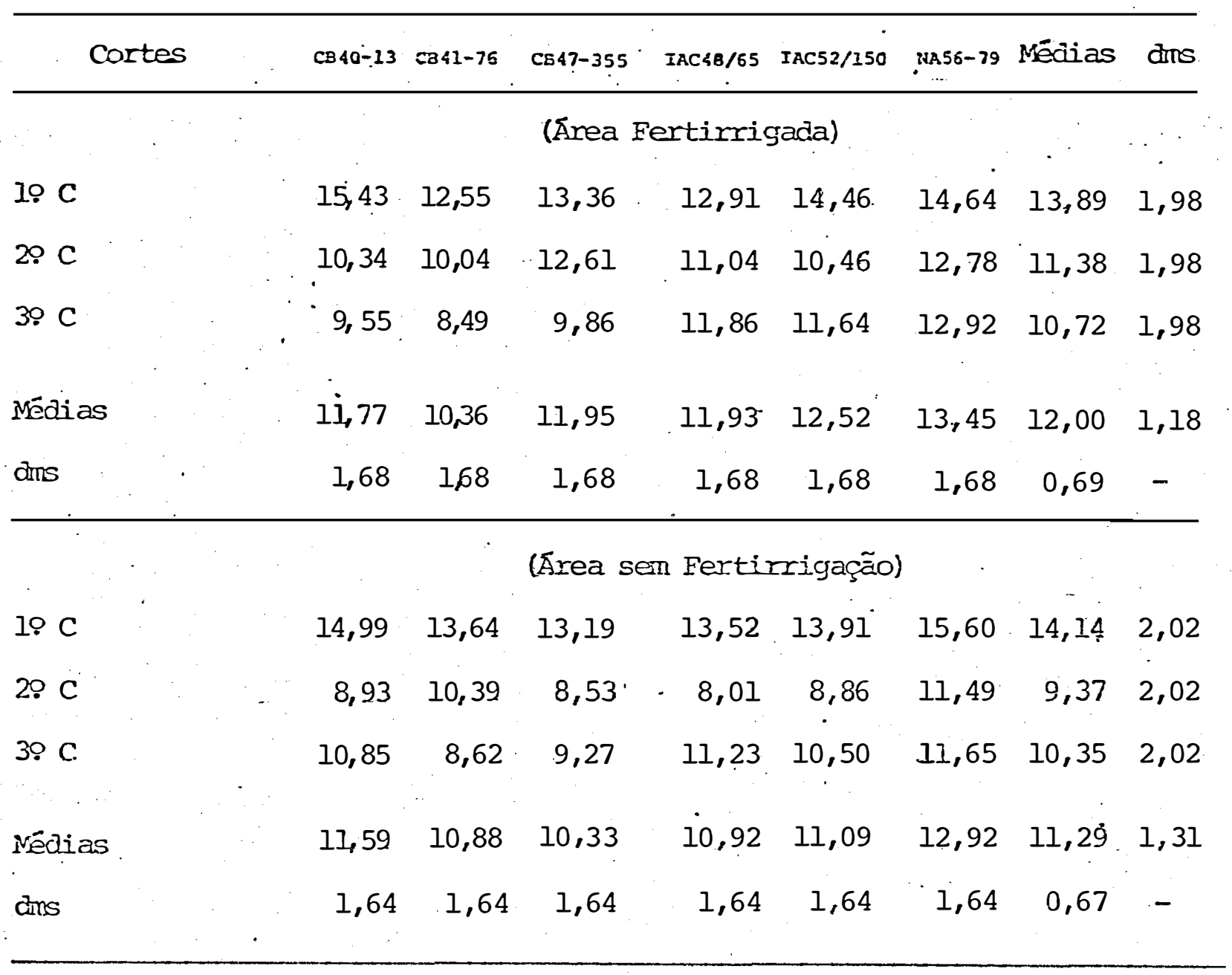


hectare, quilos de açúcar teórico recuperável (ATR) por tonelada de cana e litros de álcool provável direto (EPD) por tonelada de cana, foi possivel calcular os rendimentos teóricos de açúcar e de álcool em toneladas e metros cúbi cos por hectare, respectivamente. Os resultados médios es tão na Tabela 20 e 21, assim como os valores da diferença minima significativa (dms).

Adotando os mesmos critérios utilizados nos parâmetros anteriores, as variedades podem ser relativamen te classificadas quanto à produtividade de açúcar na esca la a seguir:

Ārea Fertirrigada

Ārea sem Fertirrigação

$\begin{array}{lrccllll}\text { Variedades } & t / h a & \text { Tukey } & \text { Classif. } & \text { Variedades } & t / h a & \text { Tukey } & \text { Classif. } \\ \text { NA56-79 } & 13,45 & \text { a } & \text { alta } & \text { INA } 56-79 & 12,92 & \mathrm{a} & \text { alta } \\ \text { IAC52/150 } & 12,52 & \text { a b. } & \text { alta/média } & \text { CB40-13 } & 11,59 & \mathrm{~b} & \text { média } \\ \text { CB47-355 } & 11,95 & \text { b } & \text { média } & \text { IAC52/150 } & 11,09 & \mathrm{~b} & \text { média } \\ \text { IAC48/65 } & 11,93 & \text { b } & \text { média } & \text { IAC48/65 } & 10,92 & \mathrm{~b} & \text { média } \\ \text { CB40-13 } & 11,77 & \text { b } & \text { média } & \text { CB41-76 } & 10,88 & \mathrm{~b} & \text { média } \\ \text { CB41-76 } & 10,36 & \text { c } & \text { baixa } & \text { CB47-355 } & 10,33 & \text { b } & \text { média }\end{array}$

Deste modo, a variedade NA56-79 destacou-se significativamente em ambos os ensaịos, devido à excelente resposta à fertirrigação em termos de desenvolvimento vegetą tivo, com aumento da produtividade de colmos ( $t / h a)$, embora com prejuizo do rendimento de ATR. A variedade IAC52/150 mos trou-se adequada para cultivo tanto na área fertirrigada co mo na área sem fertirrigação, devido ao seu alto teor de sa carose, confirmando BASSINELLO et alii (1976) e SEGALLA e TOKESHI (1981).

A variedade CB47-355 fertirrigada revelou me lhor classificação do que sem fertirrigação. O comportamento desta variedade, de acordo com SEGALLA e TOKESHI (1981), apresenta em solos de boa fertilidade natural altas pro 
- Tabela 21. Resultados médios de produtividade de álcool (m3/ha) e diferença mínima significativa (dms) pelo teste de Tukey ao nível de 5\% de probabilidade

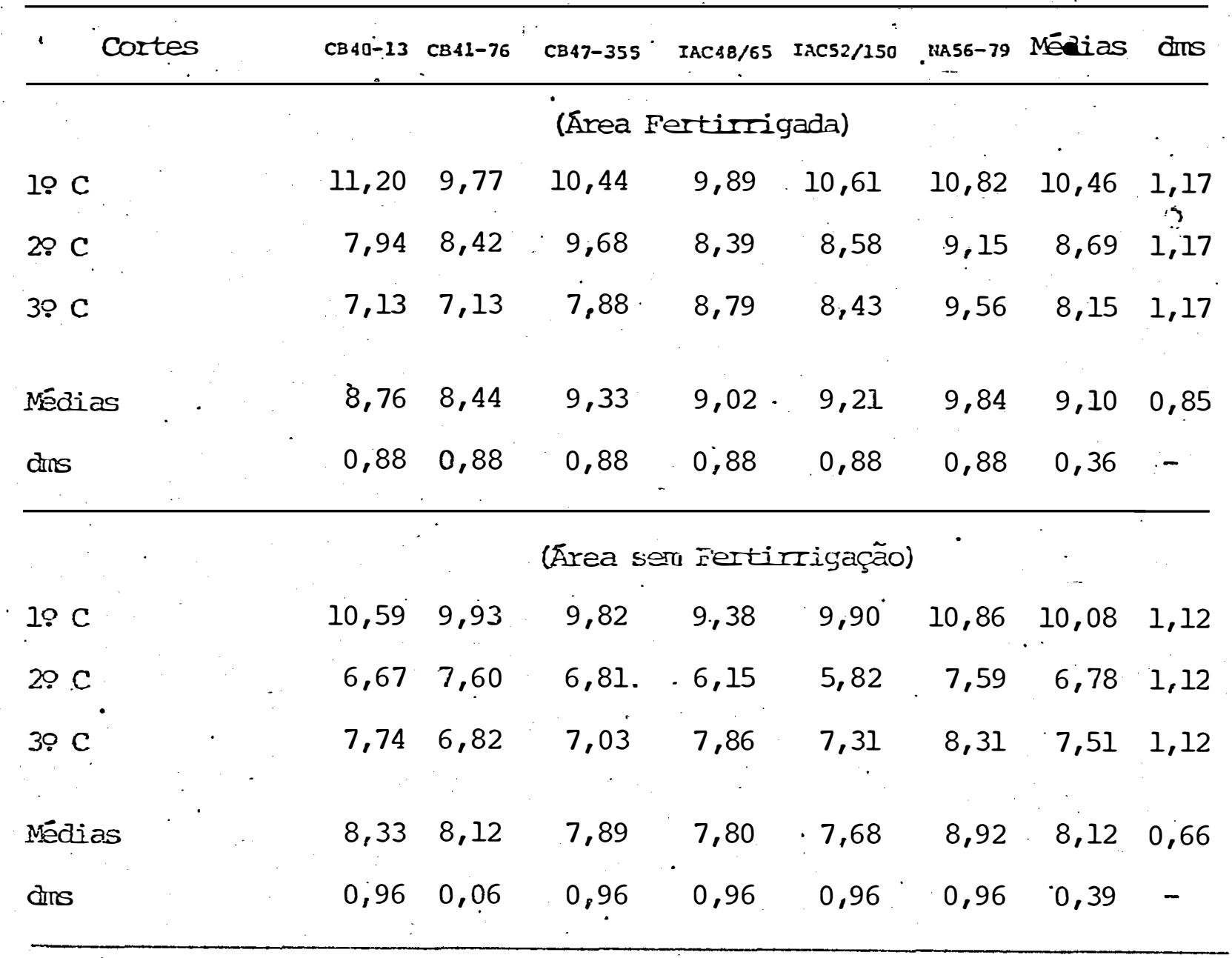


dutividades; mas nos dois ensaiós foi çlássificada como mé dia no mês de setembro.

o rendimento teórico de álcool da Tabela 21 permitiu que as variedades fossem classificadas na seguin te escala:

Area Fertirigada

Variedades $\mathrm{m}^{3}$ ha Tukey Classif. Variedade $\mathrm{m}^{3}$ ha Tukey Classif. NA56-79 9,84

CB47-355 9,33 IAC $52 / 150 \quad 9,21$

IAC48/65 9,02

CB40-13 8,76

CB $41-76$

\begin{abstract}
a
\end{abstract} alta ab alta/média abc média abc - média b c média/baixa c baixa
Ārea sem 'Fertirrigação NA56-79 8,92 a alta CB40-13 8,33 a b CB4l-76 8,12 b CB 47-355 7,89 b b média b média b média

A melhor variedade para produção dé àlcool é a mesma para produção de açúcar, ou seja, a NA56-79. A vạ riedade de IAC52/150 apresentou rendimentos de nível médio nos dois ensaios, embora no ensaio sem fertirrigação tenha resultado, a menor média. A variedade CB47-355 revelou no vamente melhor classificação na ārea fertirrigada, enquanto que a CB40-13 ficou em melhor posição no ensaio sem fertir rigação. Estes fatos sugerem que hã um efeito varietal na resposta à fertirrigação, como demonstraram os dados de SILVA at alii, (1976).

A variedade CB41-76 ficou em último lugar quanto aos rendimentos teóricos de açúcar e álcool por hectare no ensaio fertirrigado, sendo que na área sem fer tirrigação apresentou classificação média, principalmente em termos de produtividade de álcool, devidoa produtividade de colmos por hectare ter sido alta.

O terceiro corte no ensaio sem fertirrigação mostrou maiores produtividades de açūcar e álcool que o 
segundo corte (Tabelas 20 e 21), devido à melhor qualidą de das variedades na safra 1981/82.

Comparando-se a média geral dos dois en saios, observa-se que a fertirrigação elevou a produtivida de de açúcar em $710 \mathrm{~kg} / \mathrm{ha}$, resultando 82,8 litros de álcool residual para una relação de 7 litros por saco de açūcar de $60 \mathrm{~kg}$.(COPERSUCÁR, 1979), e a produtividade de álcool direto em 980 litros/ha. Entretanto, para este. acréscimo dos produtos foi necessário colher e processar mais 29 t de colmos/ha, o que representa um considerável cussto adicional. Por este motivo, há necessidade de se efetuar um estudo econômico para definir se a receita gerada pelos produtos (açúcar e/ou álcool) é maior do que os custos da colheita e moagem, e acrescidos da diferença entre os cus tos da feitirrigação e adubação mineral. Deve-se consi derar que a vinhaça e as águas residuais da lavagem de cana devem receber uma solução quanto à destinação destes efluentes, o que representará outro custo a ser considerado para comparação dos sistemas.

Por outro lado, hä possibilidade de se cul tivar a área fertirrigada por maior número de cortes (ROSSETTO at alii, 1978) em relação ao setor sem fertirriga ção, o.que representa menores custos com reforma e. plan tio por hectare cultivado. 


\section{CONCLUSÕES}

Os resultados obtidos com seis variedades em três cortę com e sem fertirrigação, permitiram as seguin tes conclusões:

- há um efeito varietal quanto à resposta em produtividade de açúcar ou álcool teóricos por hectare devido a fertir rigação;

- a variedade NA56-79 revelou um comportamento superior às dẹmais variedades tanto em área fertirrigada como sem fertirrigação, em termos de produtividade de açúcar ou àlcool;

- no ensaio fertirrigado a IAC52/150 mostrou o mesmo nível de produtividade de açúcar e ảe álcool da NA56-79, repre sentando por este motivo a segunda opção de plantio • nes tas áreas, entre as variedades estudadas;

- a colheita da área fertirrigada deve ser realizada no ini cio da safra (maio e junho) para liberação da área para a fertirrigação, o que confirma as variedades NA56-79 e IAC52/150 como indicadas para estas condições, devido a 
curva de maturação destas variedades;

- as variedades CB47-355, IAC48/65 e CB40-13 não são indica das para áreas fertirrigadas, embora a primeira possa ser outra opção para colheita após meados da safra;

- - sob condições fertirrigadas, a variedade CB41-76 não apre sentou produtividades que justifiquem seu cultivo.

- para condições sem fertirrigação, à exceção da NA56-79, tó das as variedades situam-se em niveis semelhantes em ter mos de produtividade de açúcar ou álcool por hectare, de vido à alta fertilidade natural do solo utilizado, só bressaindo-se a CB40-13 logo após a NA56-79. 


\section{BIBLIOGRAFIA}

AGUJARO, R., 1979. O Uso da vinhaça na Usina Tamoio como fertilizante. Saccharum-Stab. São Paulo, 2 (4): 23-27 , mar.

ALMEIDA, J. R. de, 1952. O problema da vinhaça em são Paulo. Boletim do Instituto Zimotécnico. Piracicaba, $24 \mathrm{p}$.

ALMEIDA, J.R. de, G. RANZANI, e O. VALSECHI, 1950. A Vi nhaça na agricultura. Boletim do Instituto Zimotécnico. Piracicaba, (l): $21 \mathrm{p}$.

BAJPAI, P. D. E S. P. DUA, 1972. Studies on the utility of distillery effluent (spend wash) for its manurial value and its effect on soil properties. Indian Sugar. 687-689, jan.

BASSINELLO, A. I., 1975. Características agroindustriais de algúmas variedades comerciais. Brasil Açucareiro. Rio de Janeiro, 86 (4): 348-350, out. 
BASSINELLO, A. I.; S. MASUOKA e A. C. MENDES, 1976. Varie dades de cana-de-açūcar para o Estado de são Paulo. Bo letim Técnico Planalsucar - IAA. Araras (3): 20 p.

BRIEGER, F., 1978. Situação do melhoramento da cana-de-açūcar no Estado de São Paulo. Saccharum-Stab. São Paulo, $1(2)$ : 13-16, set.

CACKETT , K. E. e J. J. RAMPF, 1981. Sugarcane for ethanol-Should field management pratices be - modified? Part 1.- Variety and seasonal influences. In: Proc. South African Sug. Technol. Assoc.. Durban, p. 154-160.

CATANI, R. A. e A. O. JACINTHO, 1974. Avaliação da fertí . lidade do solo: Métodos de Análises. Departamento de Química. E. S. A. "Luiz de queiroz". Piracicaba, 52 p.

CIARKE, M. A., 1981. Potash: Potential profits or - pro blems. Sugar Journal. Louisiana, 43 (10): 18.

COPERSUCAR - São Paulo, 1978. Estudos sobre a implantação no Brasil de um sistema de pagamento de cana-de-açúcar pela qualidade. São Paulo, $97 \mathrm{p}$.

COPERSUCAR - São Paulo, 1979. Estudo da paridade técnico-econômica entre o açúcar e álcool. Piracicaba - SP , $77 \mathrm{p}$.

COPERSUCAR - São Paulo, 1980a. Combate à poluição: Avalia ção do programa Copersucar. Piracicaba, 2a. ed., 45 p.

COPERSUCAR - São Paulo, 1980b. Amostragem e análise da cana-de-açúcar. são Paulo, 37 p. 
COPERSUCAR - São Paulo, 1980c. Aplicação da vinhaça à so queira da cana-de-açúcar em três anos consecutivos. Bo letim Técnico Copersucar. São Paulo, (12): 2-5.

COPERSUCAR - São Paulo, 1982a. Características das varie dades SP da série 70. In: I Seminārio de Tecnologia A gronômica. Piracicaba: 17-31.

COPERSUCAR - São Paulo, 1982b. o carvão da cana-de-açúcar e a variedade NA56-79 no Estado de São Paulo. In: I Seminārio.de Tecnologia Agronômica. Piracicaba: 85-91.

COPERSUCAR - São Paulo, 1982c. Resultados obtidos pelo "Controle Té̀cnico Agronômico" na safra 81/82. In: I Seminärio de Tecnologia Ayronômica. São Paulo: p. 241-252 .

GLÓRIA, N. A. da; A. G. SANT'ANA e H. MONTEIRO, 1972. Com posição dos resíduos de açūcar e destilarias de àl cool durante a safra canavieira. Brasil Açucareiro . Rio de Janeiro, 80 (5): 542-548, nov.

GLÓRIA, N. A. da e J. A. MAGRO, 1977. Utilização agrîco la dos resíduos de usinas de açúcar e destilarias na Usina da Pedra. In: IV Seminärio Copersucar da Agroin dūstria Açucareira. Aguas de Lindōia, p. 163-180.

GLóRIA, N. A. da, 1976. Emprego da vinhaça para fertili zação. Piracicabä, Codistil: $32 \mathrm{p}$ :

GOSNELI, J. M. e M. J. P. KOENIG, 1972. Some effects of varieties on seasonal fluctuation in cane quality. In: Proc. South African Sug. Techn. Assoc.. Durban: p. 188-195. 
IAA. - PLANALSUCAR, 1979. Relatório Anual 1978. Piracica ba: $98 \mathrm{p}$.

IAA - PLANALSUCAR, 1980. Relatório Anual 1979. Piracicaba: $100 \mathrm{p}$.

IAA - PLANALSUCAR, 1981. Relatório Anual. 1980. Piracicá ba: $116 \mathrm{p}$.

JUNQUEIRA, A. A. B. e B. DANTAS, 1964. A cana-de-açūcar no Brasil. In: Cultura e adubação de cana-de-açūcar - Insitituto Brasileiro de Potassa. São Paulo: p. 27-60 .

LEVERINGTON, K. C.; D. M. HOGARTH e G. J. HAM, 1978. The influence of time of harvest on yields in the Burdekin District. In: Proc. Queensland Soc. Sugarcane Tech nol. Queensland: p. 27-30.

LINGERFELT, C. W.; T. O. ELIIS e G. ARCENEAUX, 1965. Va rietal relationships in available sugar content as affected by period of harvest. In: proc. Intern. Soc. Sugarcane Technol. Puerto Rico: p. 474-478.

LONSDALE, J. E. e J. M. GOSNELL, 1975. Effects of age and harvest season on the yield and quality of sugar cane. In: Proc. South African Sug. Technol Assoc. Dur ban: p. 177-182.

LONSDALE, J. E. A J. M. GOSNELL, 1976. Growth and quali ty of four sugarcane varieties as influenced by age and season. In: Proc. South African Sug. Technol. As soc. Durban: p. 82-86. 
LORENZETTI, J. M. A P. G. R. FREITAS, 1978. Aplicação de vinhaça por aspersão. Saccharum-Stab. São Paulo, 1 (2) : 16-22, mar.

MAGRO, J. A. e N. A. da GLORIA, 1977. Adubação de soquei ra de cana-de-açūcar com vinhaça. Complementação com nitrogênio e fósforo. Brasil Açucareiro. Rio da Jâ neiro, 90 (6) : 363-366, dez .

MIOCQUE, J., 1980. O valor relativo da cana-de-açúcar Saccharum-Stab. São Paulo, $3(10): 31-33$, set.

ROSSETTO, A. J.; L. C. L. RESENDE; J. C. ALONSO; S. BUS SIOLI FO; L. N. MARGUERON; J.A. SILVA E L. C. MILLER, I978. Sistemas de distribuição de vinhaça na Usina São João. Saccharum-Stab. São Paulo, 1 (3): 37-47, mar.

ROSSLER, L. A. A P. K. MOBERLY, 1972. Further results from experiments with five varieties harvested at dif ferent ages. In: Proc. South African Sug. Technol. As soc. Durban: p. 177-180.

ROSTRON, H., 1972. The effects of age and time of har vest on the produtivity of irrigated sugarcane. In: Proc. South African Sug. Technol. Assoc. Durban: p. 142-150.

SEGALLA, A. C. e H. TOKESHI, 1981. Variedades de cana-de-açúcar para o Brasil. Brasil Açucareiro. Rio de Janeiro, 98 (6): 430-436, dez. 
SILVA, G. M. de A.; J. L. P. de CASTRO e J. A. MAGRO

1976. Comportamento agroindustrial da cana-de-açúcar em solo irrịgado e não irrigado com vinhaça. In:Anais IV Seminārio Copersucar Agroindustrial Açucareiro e Alcooleiro. - Copersucar. Aguas de Lindóia: 107-122.

SILVA, G. M. de A.; L. J. P. de CASTRO; A: C. SANCHES ; E. GUIMARÃES e M. A. N. GURGEL, 1978. Efeitos da apli cação da vinhaça como fertilizante em cana-de-açúcar . Boletim Técnico Copersucar. São Paulo, (7): 9-14.

SILVA, L. C. F. da; O. ALONSO; J. ORLANDO FO e E. ZAMBEL LO Jr., 1981. Complementação nitrogenada da vinhaça . II - Formas de aplicação em solo TE. Brasil Açucarei ro. $98(5): 59-65$, nov.

SOBRAL, A. F.; D. A. CORDEIRO e M. A. C. dos SANTOS,1981. Efeitos da aplicação da vinhaça em soqueiras da cana-de-açúcar. Brasil Açucareiro. Rio de Janeiro, 98 (5) : 52-58, nov.

STUPIELLO, J. P.; C. A. PEXE; H. MONTEIRO e L. H, SILVA, 1977. Efeitos da aplicação da vinhaça como fertilí zante na qualidade da cana-de-açúcar. Brasil Açucare ro. Rio de Janeiro, 90 (3): 185-194, mar.

STURION, A. C. e A. C. FERNANDES, 1979. Análise direta da cana-de-açúcar pelo método da prensa hidráulica. Bo letim Técnico Copẹrsucar. São Paulo, (8):-12-15.

TANIMOTO, T., 1964. The press method of cane analysis Hawaiian Planters' Record. Honolulu, 57 (2): 133-150. 
APENDICE 


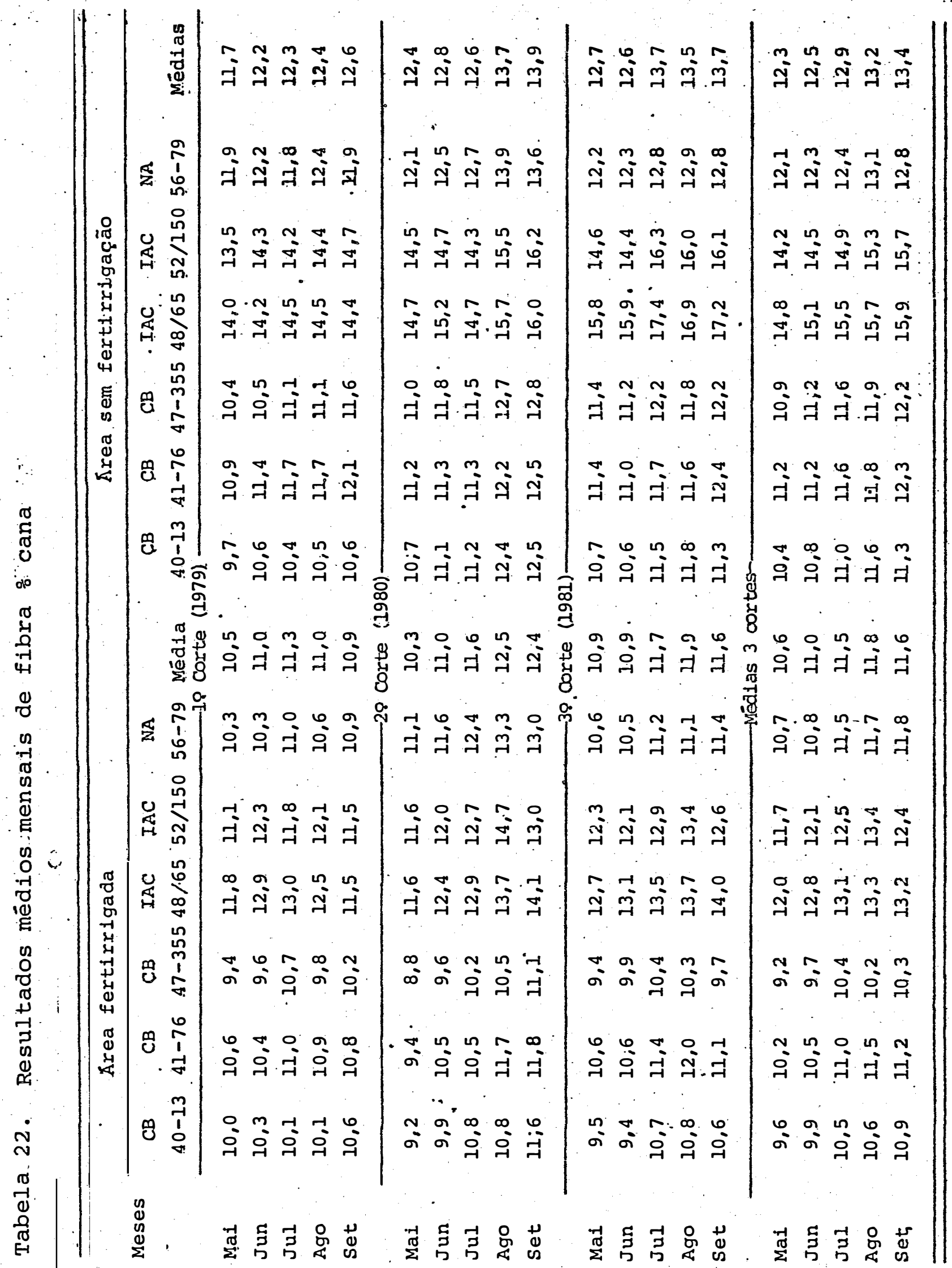




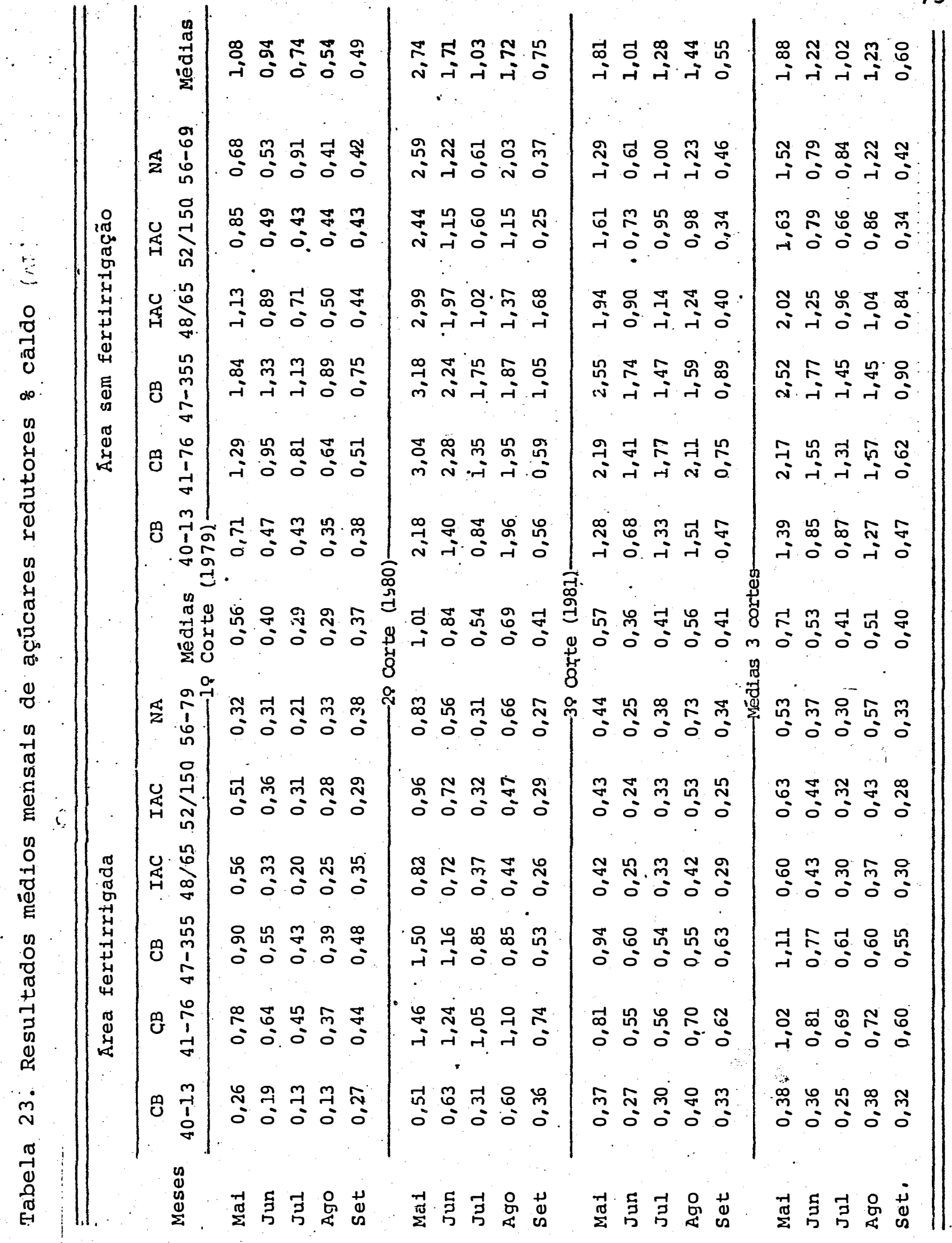




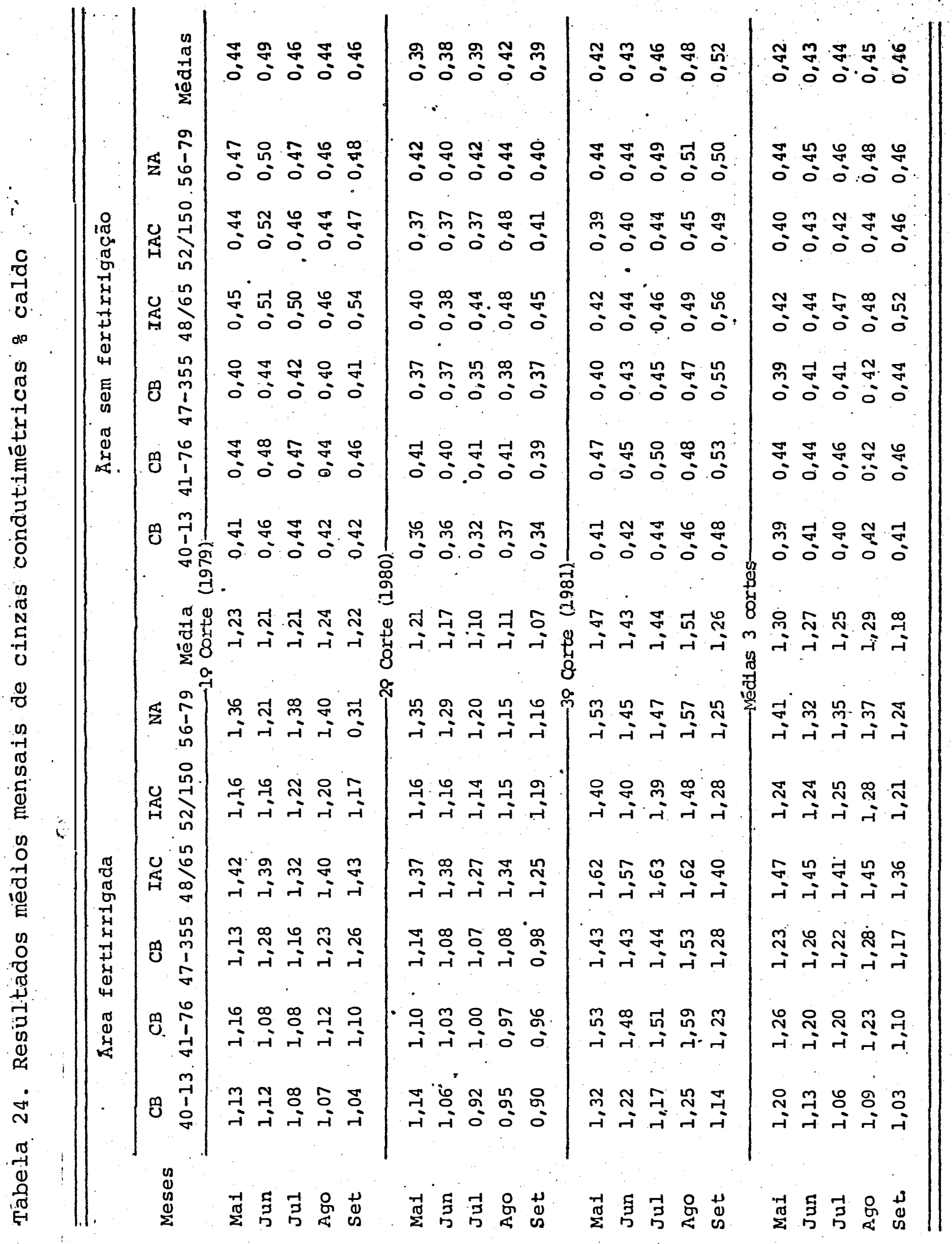




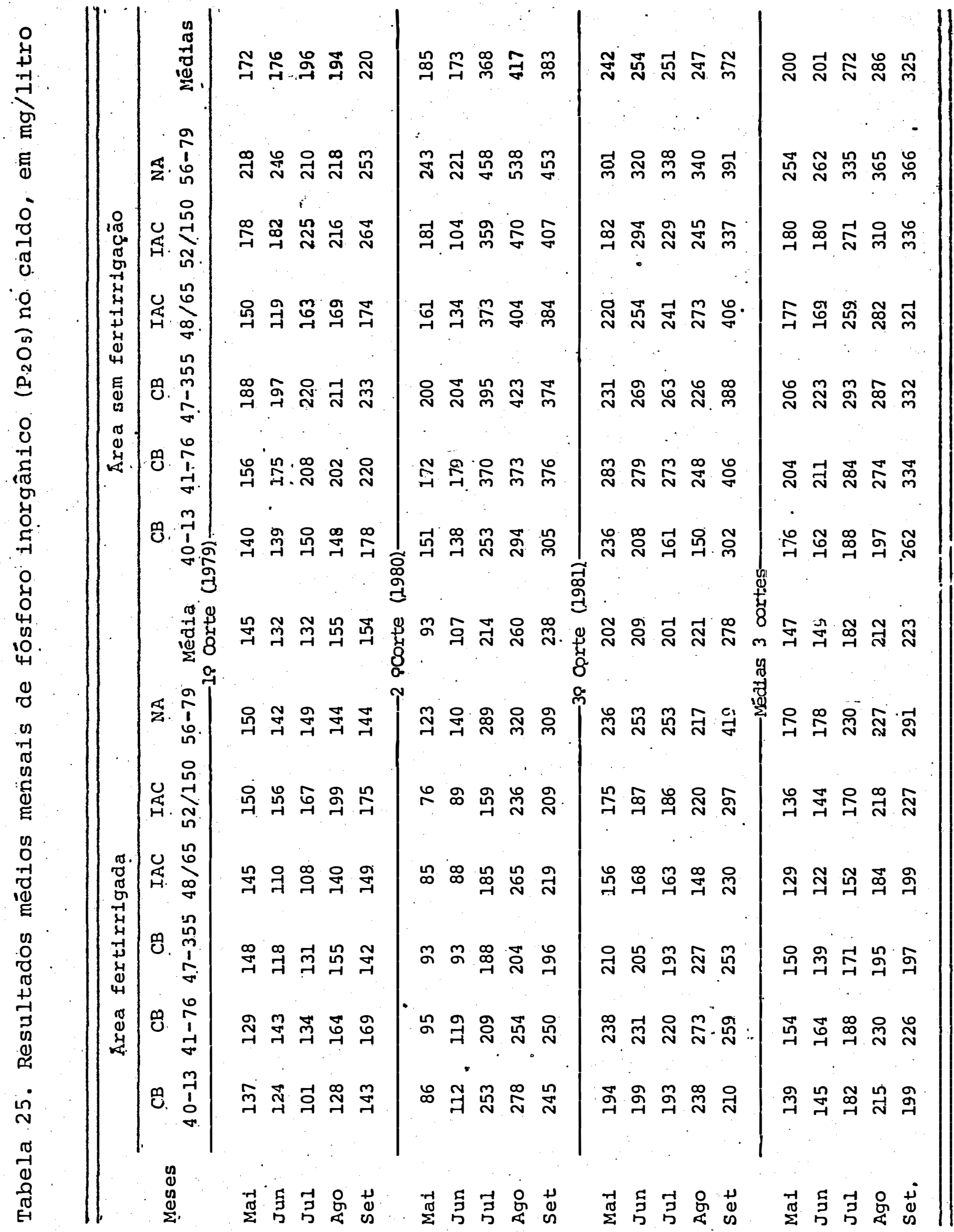




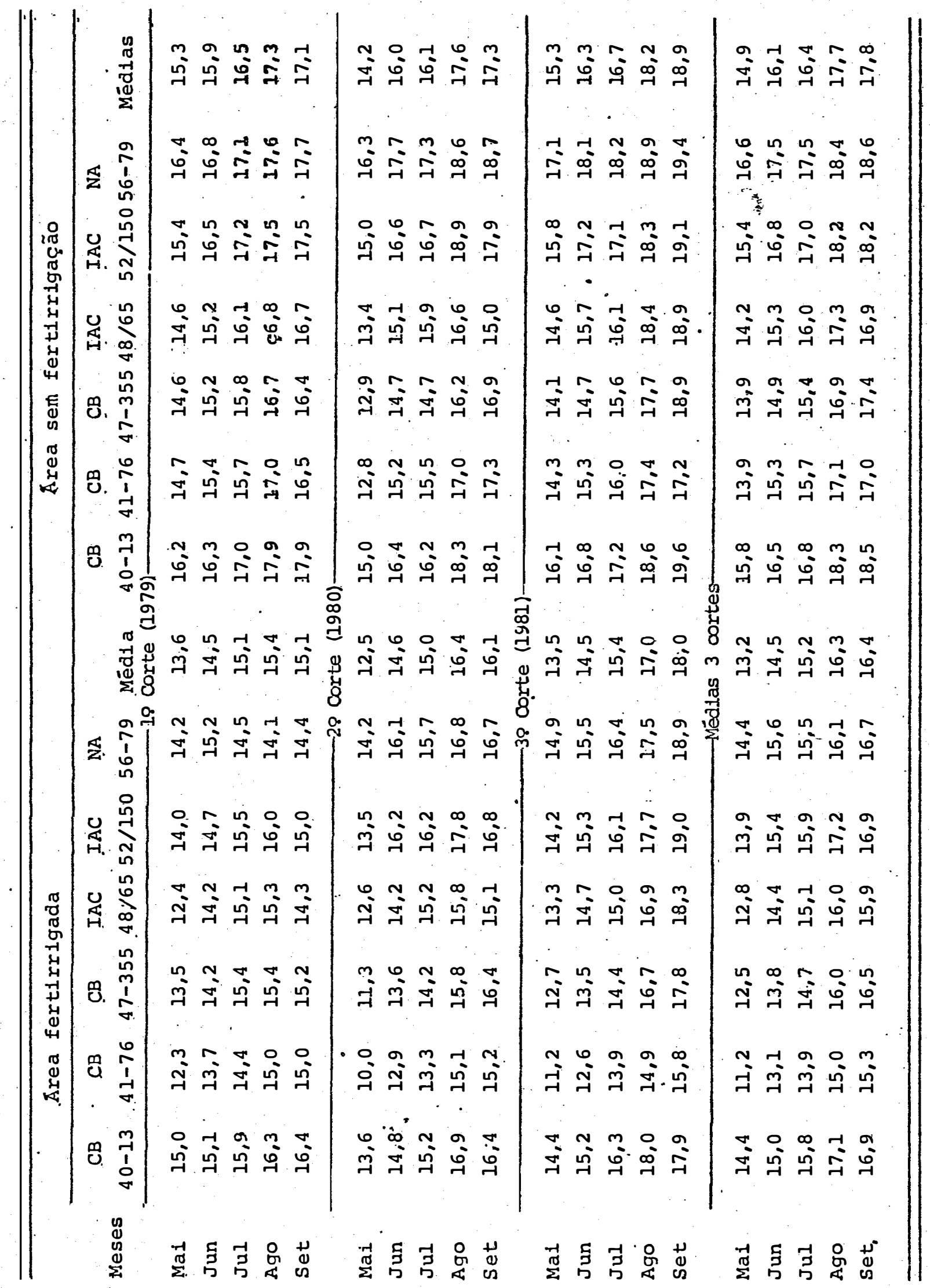




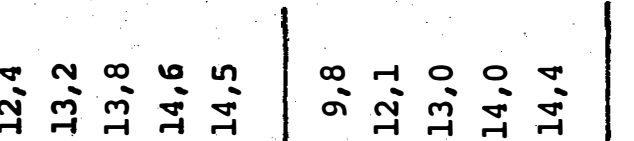

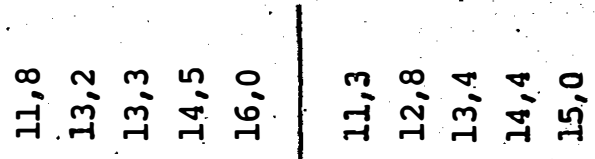

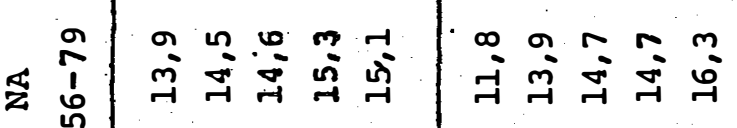

m

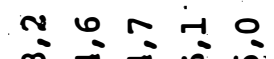
m

U

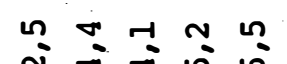

$\neg \neg \approx \sigma 0$

भัन

กั

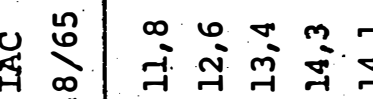

बेन

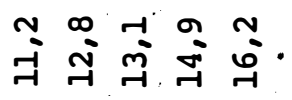

ก $N-1$ ก

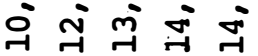

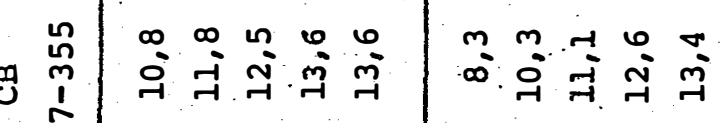

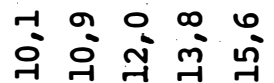

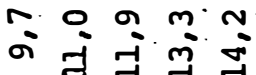

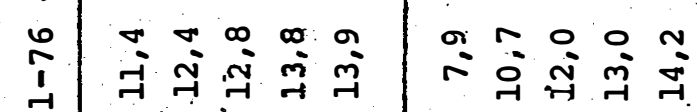

(2)

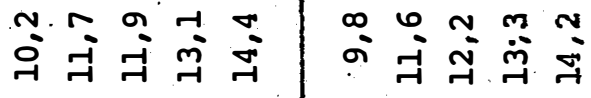

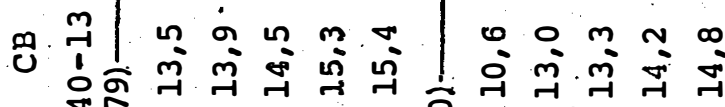
a

op

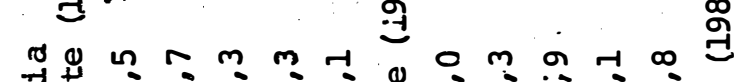

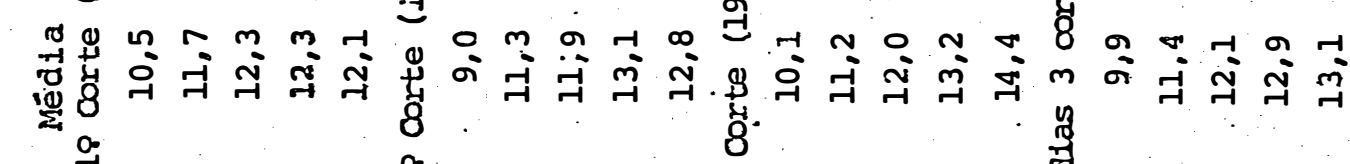

ㅇ.

๔

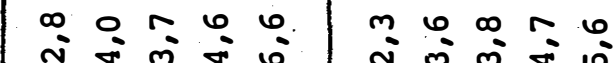

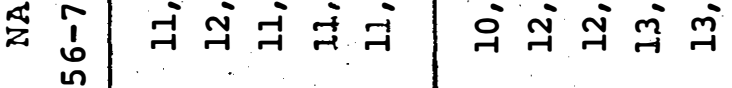

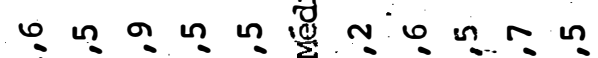

(4)

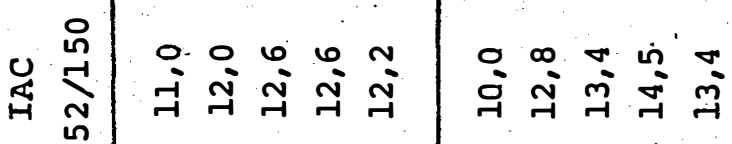

芹

สี่ กี กี

ન્ન

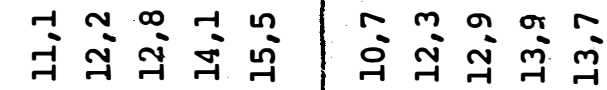

ํำ

n $m \circ \infty n$

น

*

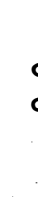

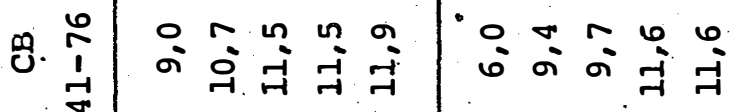

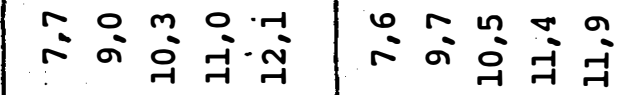

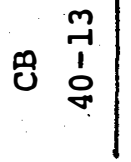

テै

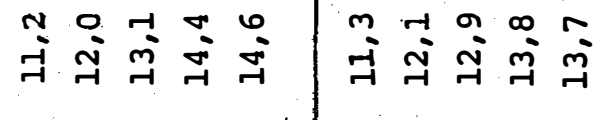




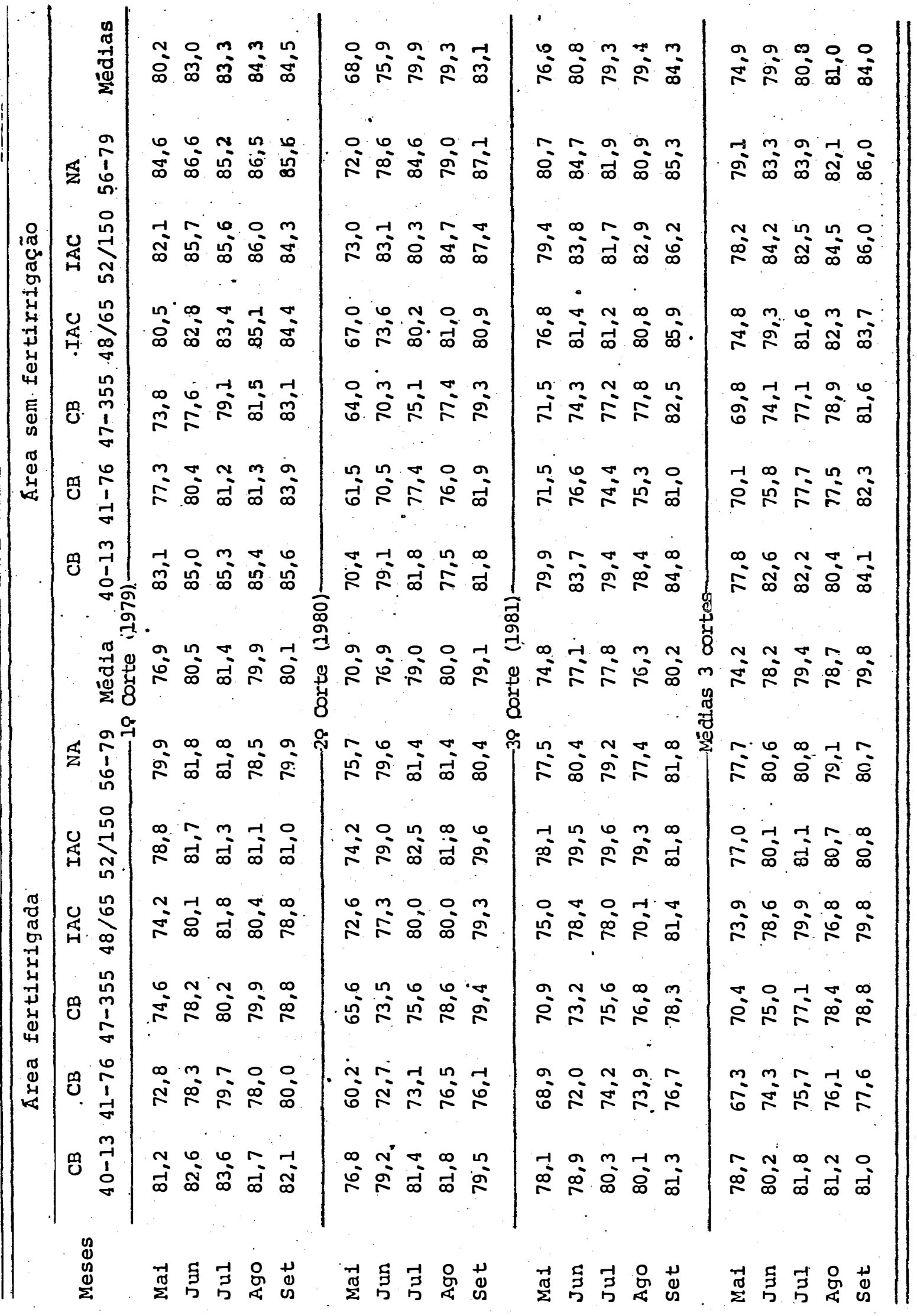




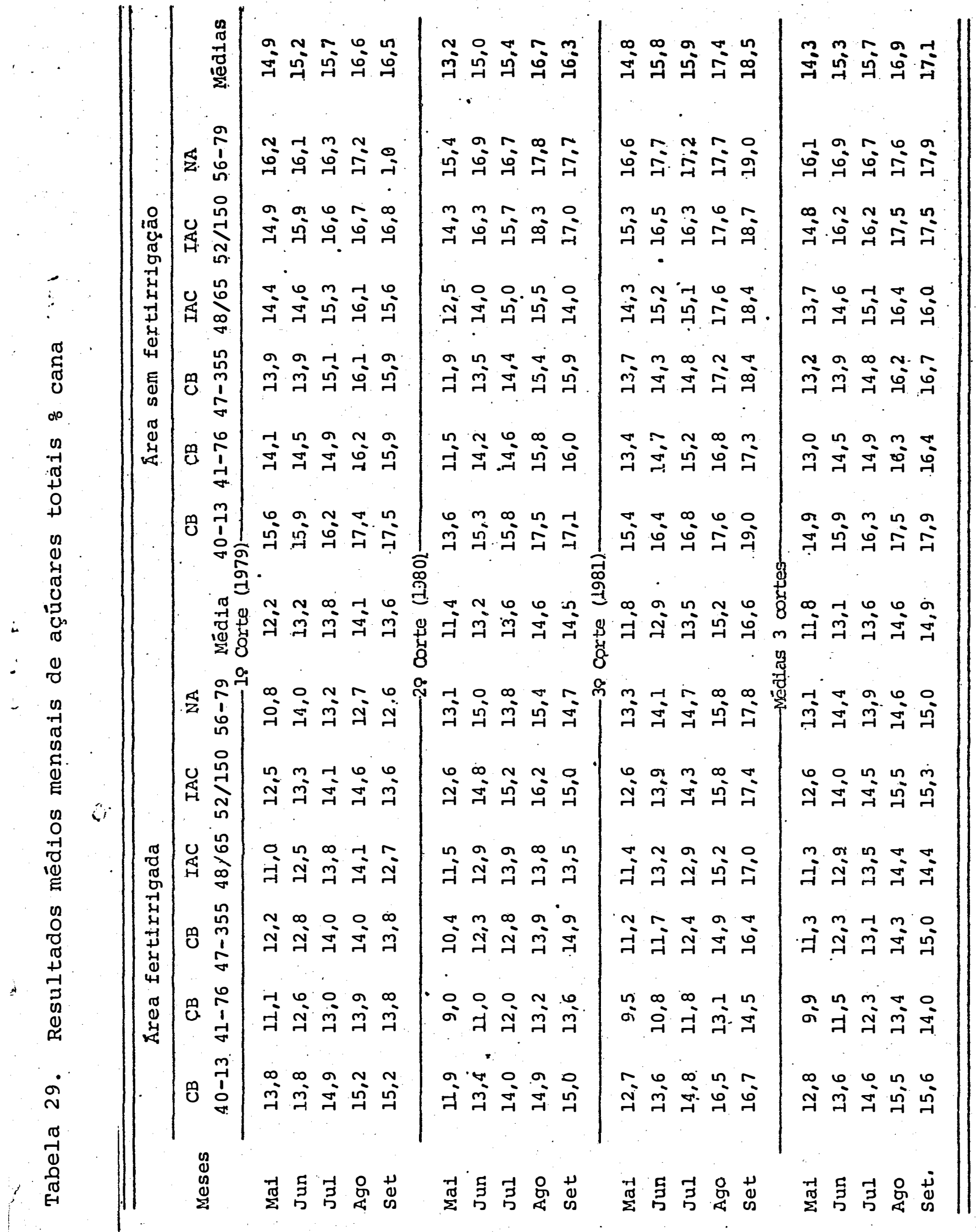




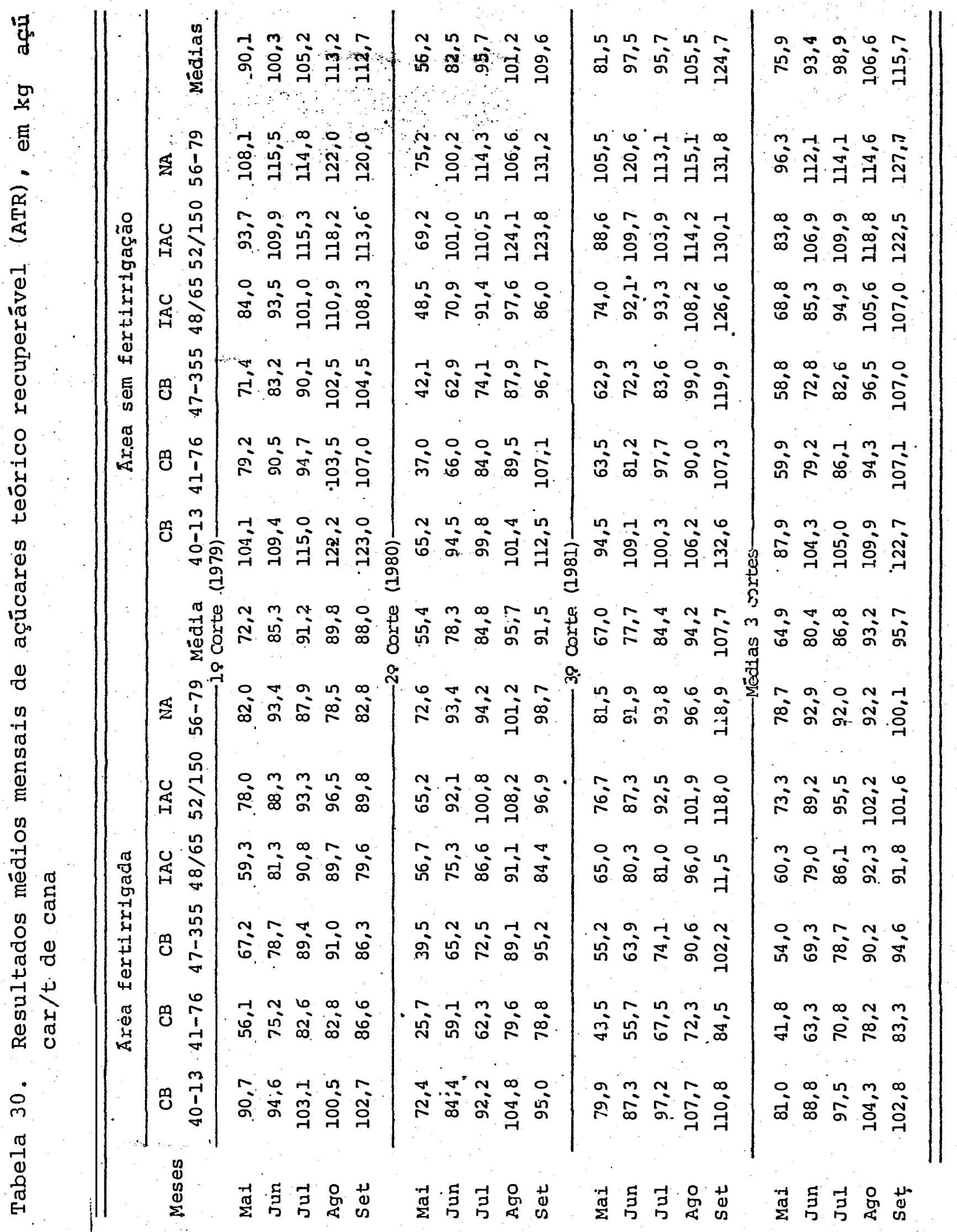

